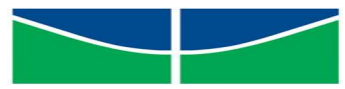

UNIVERSIDADE DE BRASÍLIA

Faculdade de Ciência da Informação

PROGRAMA DE PÓS-GRADUAÇÃO EM CIÊNCIA DA INFORMAÇÃO

Lívia Ferreira de Carvalho

FORMAÇÃO CONTINUADA EM LETRAMENTO INFORMACIONAL NA MODALIDADE EAD DE PROFESSORES E BIBLIOTECÁRIOS 


\title{
FORMAÇÃO CONTINUADA EM LETRAMENTO INFORMACIONAL NA MODALIDADE EAD DE PROFESSORES E BIBLIOTECÁRIOS
}

\begin{abstract}
Tese apresentada em banca de defesa de doutorado como requisito para a obtenção do título de doutor em Ciência da Informação pelo Programa de Pós-graduação em Ciência da Informação da Universidade de Brasília.
\end{abstract}

Área de concentração: Gestão da Informação

Linha de pesquisa: Comunicação e mediação da informação

Orientadora: Professora Dra. Kelley Cristine Gonçalves Dias Gasque 


\section{Ficha Catalográfica}

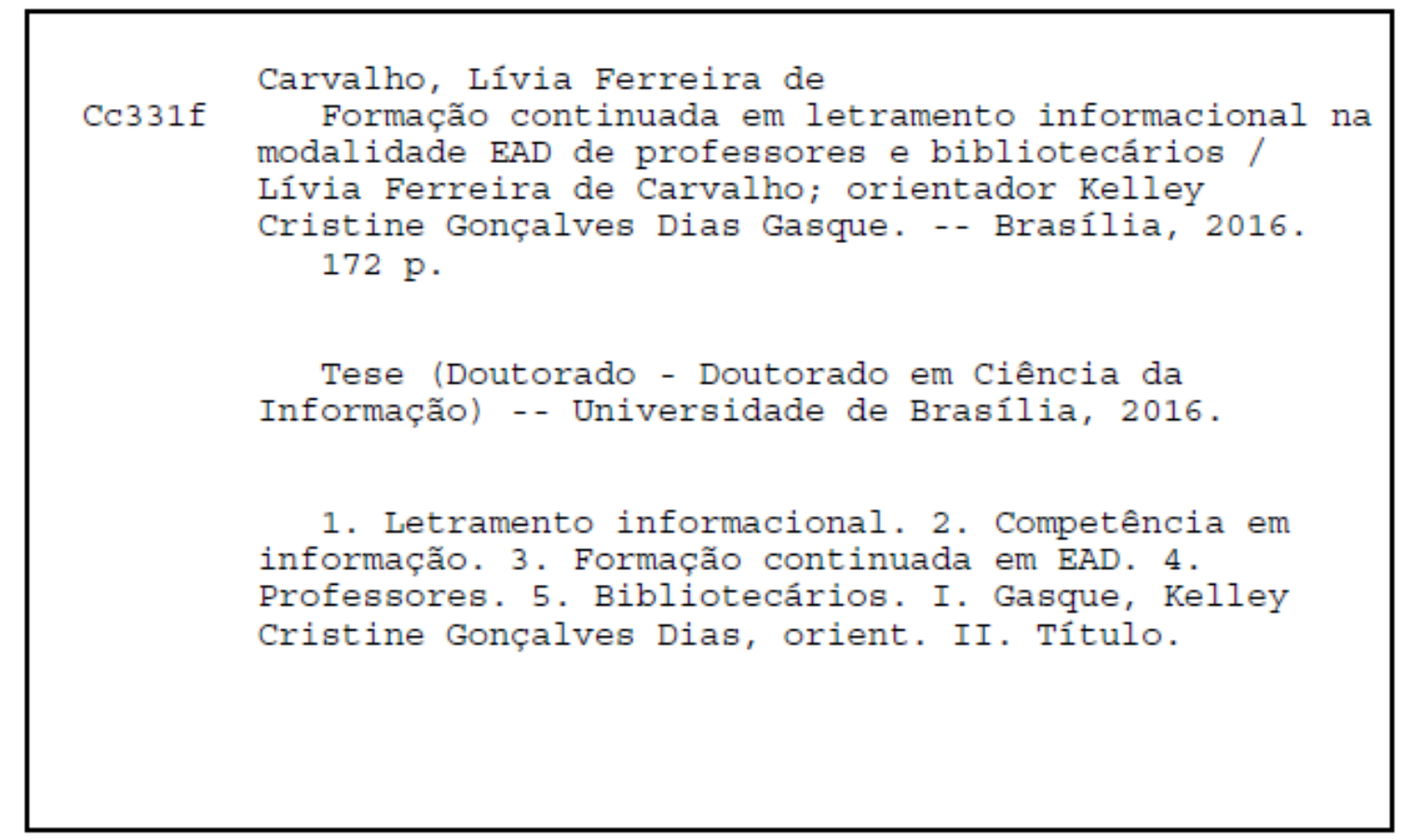




\section{FOLHA DE APROVAÇÃO}

Título: "FORMAÇÃO CONTINUADA EM LETRAMENTO

INFORMACIONAL NA MODALIDADE EAD DE PROFESSORES E BIBLIOTECÁRIOS".

\section{Autor (a): Lívia Ferreira de Carvalho}

Área de concentração: Gestão da Informação

Linha de pesquisa: Comunicação e Mediação da informação

Tese submetida à Comissão Examinadora designada pelo Colegiado do Programa de Pósgraduação em Ciência da Informação da Faculdade em Ciência da Informação da Universidade de Brasília como requisito parcial para obtenção do título de Doutor em Ciência da Informação.

Tese aprovada em: 21 de março de 2016.
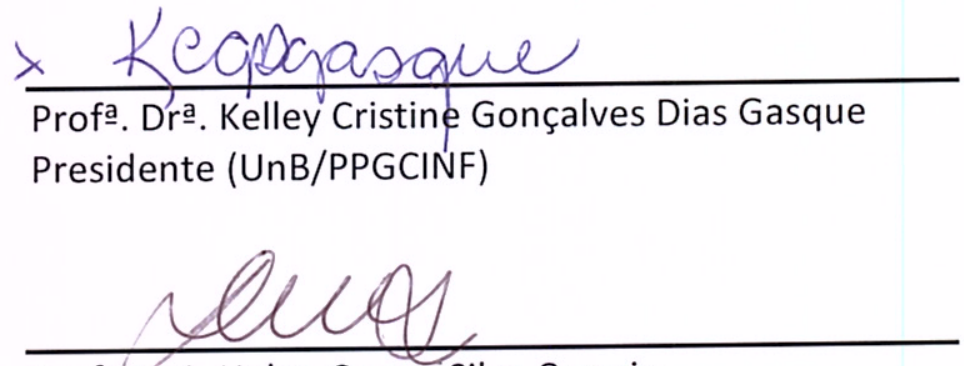

Profa. Dra. Helen Castro Silva Casarin

Membro Externo (UEP)

Profa. Dra. Solange Alfinito

Membro Externo (UnB)

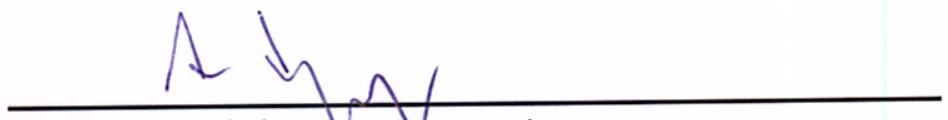

Prof. Dr. André Portto Ancona Lopez

Membro Interno (UnB/PPGCINF)

olluthivens

Profa. Dra. Elmira Luzia Melo Soares Simeão

Membro Interno (UnB/FCl)

Profa. Dra. Rosemeire Barbosa Tavares

Suplente (UnB/PPGCINF) 
"Não há ensino sem pesquisa e pesquisa sem ensino. Esses que-fazeres se encontram um no corpo do outro. Enquanto ensino continuo buscando, reprocurando. Ensino porque busco, porque indaguei, porque indago e me indago. Pesquiso para constatar, constatando, intervenho, intervindo educo e me educo. Pesquiso para conhecer o que ainda não conheço e comunicar ou anunciar a novidade". 
Dedico esta tese à minha família, maior bem que eu poderia ter. Em especial à minha bisavó Maria Antônia, mais conhecida como dona "Filinha", que me ensinou o que realmente importa na vida: amor, cuidado e respeito àqueles que amamos. 


\section{AGRADECIMENTOS}

À Deus por se manifestar em pequenas coisas do dia a dia, demonstrando como a vida é maravilhosa e quantos motivos temos para agradecer.

À minha mãe Emiliani por todo apoio emocional, incentivo e amor em todos os momentos da minha vida e durante o processo de elaboração da tese.

Ao meu filho Lucas por ser a luz da minha vida e o motivo de eu não parar de sonhar com dias melhores.

Ao Emilio, meu parceiro de alma e de vida, pelo companheirismo, amor e cuidado e pelas discussões sobre a pesquisa, as quais foram cruciais para o meu crescimento.

À Bianca, filha que ainda está no meu ventre, mas já é muito amada, e me faz querer ser uma pessoa melhor.

Ao meu pai Erivelto por cada risada nos momentos difíceis, demonstrando que apesar das dificuldades, sempre há um lado bom em todas as situações.

Aos meus irmãos Vítor e Laís por estarem presentes mesmo à distância, por todo apoio, incentivo e amor.

À minha sogra Zélia, minha cunhada Beatriz e meu sobrinho Matias por terem me acolhido em sua família com todo amor do mundo.

À minha orientadora professora Dra. Kelley Gasque, sem a qual essa pesquisa jamais seria o que é. Muito obrigada por ter sido mais que uma orientadora, mas uma parceira na elaboração desse trabalho.

À professora Dra. Suely Gomes, que me motivou a pesquisar esse tema e sempre esteve disponível para me auxiliar em diversos momentos da minha trajetória, não apenas acadêmica, mas pessoal. 
Aos professores André Lopez e Helen Casarin pelas importantes contribuições na banca de qualificação.

Aos meus amigos, sem os quais a vida seria vazia e sem graça!

Muito obrigada a todos! 


\section{RESUMO}

A pesquisa buscou identificar os elementos da formação continuada em Letramento Informacional ofertada à distância que podem impactar no desenvolvimento da competência em informação de professores e bibliotecários. Para tanto utilizou como base empírica o curso de especialização Letramento Informacional: educação para a informação - CELI, ofertado pela Universidade Federal de Goiás na modalidade EAD. Utilizou como metodologia para a coleta dos dados as abordagens quanti e qualitativa, e como técnicas a análise de conteúdo e aplicação de questionário. $O$ questionário foi aplicado aos estudantes do curso a fim de avaliá-lo e a análise de conteúdo contemplou atividades desenvolvidas por eles a fim de identificar a competência em informação nas dimensões ética, estética, técnica e política. Também foram analisados o projeto político pedagógico e o ambiente virtual de aprendizagem do curso, a fim de identificar elementos relevantes para a aprendizagem. Conclui-se que os elementos material didático, docentes, tutores, estratégias de ensino, metodologias de avaliação e o ambiente virtual de aprendizagem interferem decisivamente na qualidade de um curso EAD e, portanto, devem ser planejados de acordo com essas especificidades. Além disso, percebe-se que para trabalhar as dimensões da competência em informação de forma mais efetiva, é fundamental que as tarefas sejam direcionadas à capacidade de aplicação prática do conhecimento adquirido, necessitando assim da utilização de metodologias de avaliação da aprendizagem mais interativas e inovadoras.

Palavras-chave: Letramento Informacional. Competência em Informação. Formação continuada. Educação a distância - EAD. Professores. Bibliotecários. 


\begin{abstract}
The research aimed to identify the elements of continuing education in Information Literacy by Distance Learning that could impact on the development of information skills for teachers and librarians. Thus it was used as an empirical basis the specialization course "Information Literacy: education for the information" - CELI, offered by the Federal University of Goiás in the Distance Learning mode. The quantitative and qualitative approaches were used as a methodology for data collection, and content analysis and surveys as techniques. The surveys were applied to current students in order to evaluate it and the content analysis included activities developed by them to identify information literacy in the ethical, aesthetic, technical and political dimensions. Also were analyzed the political pedagogical project and the virtual learning environment of the course in order to identify relevant aspects of learning. We conclude that the components educational material, teachers, tutors, teaching strategies, assessment methodologies and the virtual learning environment affect the quality of a distance learning course decisively and therefore should be planned according to these characteristics. Also, understand that to work the dimensions of information literacy more effectively, it is essential that tasks are aimed at practical implementation capacity of the acquired knowledge, thus requiring the use of "assessment methodologies learning" more interactive and innovative.
\end{abstract}

Keywords: Information Literacy. Continuing education. Distance learning. Teachers. Librarians. 


\section{LISTA DE ILUSTRAÇÕES}

Figura 1 Ciclo da competência informacional

Figura 2 Resumo das características das dimensões da competência em informação

Figura 3 Pessoas que influenciam os pesquisados a ler 54

Figura 4 O que a biblioteca representa

Figura 5 Dimensões Curriculares propostas pela UNESCO para a formação de professores 62

Figura 6 Funcionamento do sistema UAB 76

Figura 7 Modelo Conceitual 87

Figura 8 Banco Internacional de Objetos Educacionais 


\section{LISTA DE QUADROS}

Quadro 1 Pesquisas publicadas entre 2010/2015 com os temas LI e EAD................. 79

Quadro 2 Categorias dos temas de pesquisas publicadas entre 2010/2015 com os temas LI e EAD

Quadro 3 Relação entre objetivos e métodos

Quadro 4 Medidas de avaliação do curso

Quadro 5 Modelo de análise de conteúdo adotado na pesquisa

Quadro 6 Análise de conteúdo da dimensão política da competência informacional

Quadro 7 Análise de conteúdo da dimensão estética da competência informacional

Quadro 8 Análise da dimensão ética da competência informacional

Quadro 9 Elementos fundamentais para estruturação de cursos EAD

Quadro 10 Análise do CELI em relação aos critérios para cursos EAD

Quadro 11 Críticas e elogios à atuação dos docentes

Quadro 12 Comentários dos estudantes sobre as Metodologias de avaliação

Quadro 13 Comentários sobre Tutoria

Quadro 14 Comentários sobre o AVA

Quadro 15 Avaliação do CELI pelos participantes do curso 


\section{LISTA DE TABELAS}

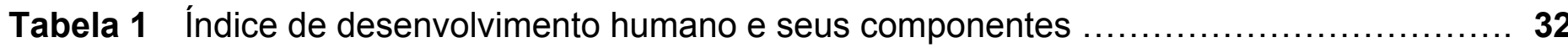

Tabela 2 Quantidade de publicações sobre competência informacional de 2001 a $2010 \ldots \ldots \ldots .37$

Tabela 3 Quantidade de publicações sobre competência informacional de 2010 a $2015 \ldots \ldots \ldots .38$

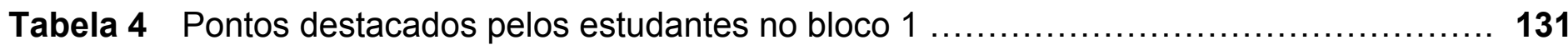

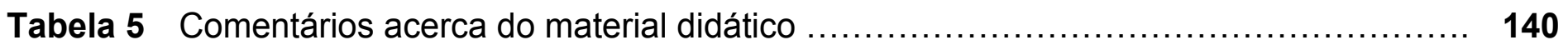

Tabela 7 Comentários dos estudantes sobre as metodologias de avaliação .................. 146

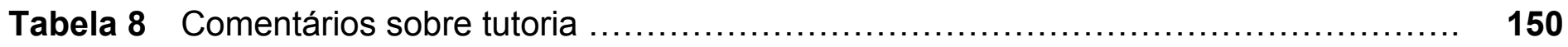

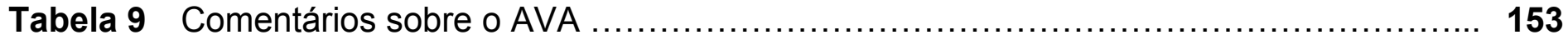




\section{LISTA DE GRÁFICOS}

Gráfico 1 Divisão do curso em eixos

Gráfico 2 Concepção pedagógica em dimensões

Gráfico 3 Conteúdo trabalhado no eixo 1

Gráfico 4 Conteúdo trabalhado no eixo 2

Gráfico 5 Conteúdo trabalhado no eixo 3

Gráfico 6 Conteúdo trabalhado no eixo 4

Gráfico 7 Conteúdo trabalhado no eixo 5

Gráfico 8 Conteúdo trabalhado no eixo 6

Gráfico 9 Capacitação docente para condução das disciplinas

Gráfico 10 Participação docente nos fóruns de discussão

Gráfico 11 Disposição do docente para auxiliar o estudante em suas dúvidas

Gráfico 12 Relacionamento interpessoal com o estudante

Gráfico 13 Condução das orientações do artigo final

Gráfico 14 Quantidade de docentes por módulo

Gráfico 15 Conteúdo dos capítulos de cada eixo temático

Gráfico 16 Atualidade e criatividade dos conteúdos

Gráfico 17 Diversificação das mídias utilizadas

Gráfico 18 Quantidade de web conferências

Gráfico 19 Estratégia de ensino adotada

Gráfico 20 Pertinência das atividades em relação ao conteúdo ministrado

Gráfico 21 Diversificação das atividades avaliativas

Gráfico 22 Atividades que exploram a capacidade de reflexão

Gráfico 23 Nível de conhecimento dos tutores à distância 
Gráfico 24 Interação dos tutores com os estudantes nos fóruns

Gráfico 25 Feedback das atividades desenvolvidas nos módulos

Gráfico 26 Capacitação dos tutores presenciais para atendimento aos estudantes

Gráfico 27 Habilidade de comunicação dos tutores presenciais

Gráfico 28 Localização dos materiais no ambiente

Gráfico 29 Comunicação por meio do ambiente

Gráfico 30 Acesso aos recursos como fóruns e chat

Gráfico 31 Download dos arquivos

Gráfico 32 Interface do ambiente 


\section{LISTA DE ABREVIATURAS E SIGLAS}

AASL American Association of School Librarians

ABED Associação Brasileira de Educação a Distância

ALA American Library Association

AVA Ambiente Virtual de Aprendizagem

CAPES Coordenação de Aperfeiçoamento de Pessoal de Nível Superior

CELI Curso de Especialização em Letramento Informacional

CIAR Centro Integrado de Aprendizagem em Rede

EAD Educação a distância

LISA Library and Information Science Abstracts

ONU Organização das Nações Unidas

TICS Tecnologias de Informação e Comunicação

UAB Universidade Aberta do Brasil

UFG Universidade Federal de Goiás

UNB Universidade de Brasília

UNESCO Organização das Nações Unidas para a Educação, a Ciência e a Cultura 
1.1 DEFINIÇÃO DO PROBLEMA

1.2 OBJETIVOS DA PESQUISA

1.2.1 Objetivo geral

1.2.2 Objetivos específicos

1.3 JUSTIFICATIVA

2.1 A INFORMAÇÃO

2.2 CONHECIMENTO, EDUCAÇÃO E CIDADANIA NA SOCIEDADE DA APRENDIZAGEM

CAPÍTULO 3 COMPETÊNCIA EM INFORMAÇÃO E LETRAMENTO INFORMACIONAL

3.1 FUNDAMENTOS TEÓRICOS DA COMPETÊNCIA EM INFORMAÇÃO E LETRAMENTO INFORMACIONAL

3.2 APLICAÇÃO PRÁTICA DA COMPETÊNCIA EM INFORMAÇÃO 39

3.3 DIMENSÕES DA COMPETÊNCIA EM INFORMAÇÃO. 44

3.3.1 Aspectos políticos da Competência em Informação 44

3.3.2 Aspectos éticos da Competência em Informação 45

3.3.3 Aspectos estéticos da Competência em Informação. 46

3.3.4 Aspectos técnicos da Competência em Informação 47

CAPÍTULO 4 PROGRAMAS DE LETRAMENTO INFORMACIONAL E A FORMAÇÃO DE PROFESSORES E BIBLIOTECÁRIOS

4.1 COMPETÊNCIA EM INFORMAÇÃO E EDUCAÇÃO 
4.2 APRENDIZADO AO LONGO DA VIDA ...................................... 55

4.3 A FORMAÇÃO DE PROFESSORES ………….................................... 58

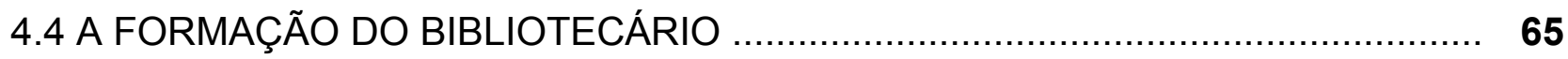

CAPÍTULO 5 A EDUCAÇÃO A DISTÂNCIA COMO ESTRATÉGIA PARA A FORMAÇÃO CONTINUADA

5.1 EDUCAÇÃO A DISTÂNCIA - HISTÓRICO E CARACTERIZAÇÃO ……............. 70

5.2 A UNIVERSIDADE ABERTA DO BRASIL - UAB .......................................... 74

5.3 EAD COMO ESTRATÉGIA PARA A FORMAÇÃO CONTINUADA EM

LETRAMENTO INFORMACIONAL............................................................... 77

CAPÍTULO 6 REFERENCIAL TEÓRICO

6.1 CONCEITOS ADOTADOS COMO REFERENCIAIS PARA A PESQUISA ........... 82

6.1.1 Sociedade da Aprendizagem ............................................................. 83

6.1.2 Letramento Informacional e Competência em Informação ............................ 83

6.1.3 Formação continuada de professores e bibliotecários ............................... 84

6.1.4 Educação a distância para a formação continuada ..................................... 85

6.2 MODELO CONCEITUAL ….................................................................... 86

CAPÍTULO 7 MÉTODO DA PESQUISA

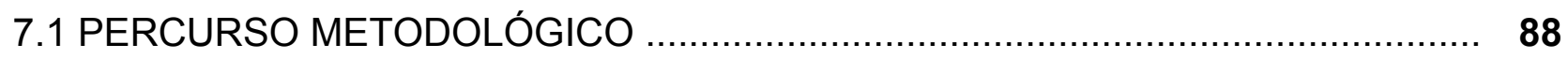

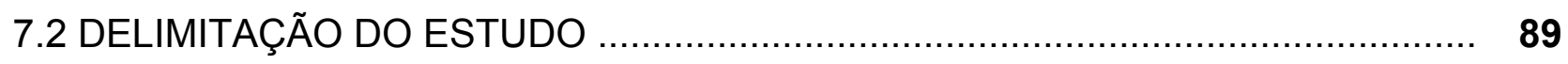

7.2.1 População estudada .................................................................................. 91

7.2.2 Método e técnica adotados .................................................................... 91

7.2.3 Instrumentos de coleta de dados ............................................................... 92

7.2.3.1 Análise de conteúdo ............................................................................... 93

7.2.3.2 Análise da Estrutura e Projeto político pedagógico do curso ........................... 96

7.2.3.3 Questionário estruturado Avaliativo do Curso ..................................... 97 
8.1 ANÁLISE DA COMPETÊNCIA EM INFORMAÇÃO DOS PARTICIPANTES DO CELI

8.1.1 Dimensão política

8.1.2 Dimensão estética

8.1.3 Dimensão ética

8.1.4 Dimensão técnica

8.2 ANÁLISE DO PROJETO POLÍTICO PEDAGÓGICO DO CURSO E DO AMBIENTE VIRTUAL DE APRENDIZAGEM

8.2.1 Diretrizes para a formação continuada em letramento informacional na modalidade EAD

8.3 AVALIAÇÃO DO CELI PELOS PARTICIPANTES

8.3.1 Bloco 1 - Estrutura pedagógica do curso .

8.3.2 Bloco 2 - Docentes

8.3.3 Bloco 3 - Material didático e estratégias de ensino

8.3.4 Bloco 4 - Metodologias de avaliação

8.3.5 Bloco 5 - Tutoria

8.3.6 Bloco 6 - Ambiente virtual de aprendizagem 


\section{CAPÍTULO 1 \\ INTRODUÇÃO}

Este capítulo visa apresentar o problema, objetivos e justificativa para a elaboração desta tese. A temática está inserida na linha de pesquisa Comunicação e Mediação da Informação especificamente no tópico Aprendizagem, comportamento e letramento informacional, área que está cada vez mais consolidada na Ciência da Informação e com a qual se pretende contribuir.

\subsection{DEFINIÇÃO DO PROBLEMA}

Cada vez mais a informação e o conhecimento têm sido objeto de pesquisas, discussões e reflexões nas mais diversas áreas. A própria sociedade está em transição, passando de Sociedade da Informação para almejada Sociedade do Aprendizado. O que caracteriza tal sociedade não é meramente o acesso à informação, mas a transformação em conhecimento que possa se converter em vantagem, seja ela pessoal, competitiva ou organizacional.

Com o foco na produção do conhecimento, as pessoas precisam ser capazes de utilizar as informações que recebem de maneira crítica e reflexiva, o que se torna possível por meio de programas de formação e capacitação para lidar com a informação, que deveriam ser inseridos nas escolas, universidades, empresas e qualquer organização que deseja melhorar o desempenho. Entender os processos envolvidos na localização, recuperação, seleção, análise e uso da informação torna-se condição precípua para os profissionais das mais diversas áreas, em especial para aqueles que lidam com a informação como objeto de trabalho, como é o caso dos bibliotecários, e para os que atuam com a formação de outrem, caso dos professores.

Esses profissionais são fundamentais para que a sociedade avance no sentido de compreender a informação e o conhecimento como instrumentos indispensáveis para o desenvolvimento. Denomina-se Letramento Informacional - LI o conjunto de 
conhecimentos e habilidades necessários para a formação do indivíduo no manejo da informação. Nesse contexto, competência em informação é compreendida como o resultado de tal processo; a aplicação prática dos conhecimentos apreendidos para a tomada de decisões e resolução de problemas cotidianos.

Corroboramos com a afirmativa de Gasque e Tescarolo (2010, p.54) de que é preciso "repensar a educação básica no Brasil, principalmente a finalidade, a concepção de ensino-aprendizagem, a organização curricular, os programas de formação de professores e a infraestrutura de informação, a fim de estabelecer uma nova cultura". Por esse motivo, propomos uma pesquisa que integre os temas formação continuada de bibliotecários e professores em letramento informacional e a Educação a Distância (EAD) como ferramenta para tal formação.

$\mathrm{Na}$ agenda de discussões da Ciência da Informação, o processo de letramento informacional e o desenvolvimento da competência em informação tem tido cada vez mais espaço. Nos Estados Unidos, é um movimento consolidado que tem a base nas bibliotecas escolares que são referência em programas de letramento, graças à grande preocupação dos bibliotecários com a temática (CAMPELLO, 2003). No Brasil, esse movimento ainda é incipiente, contudo a demanda por uma educação que promova o uso da informação mediante o pensamento reflexivo e que forme professores e bibliotecários capazes de mediar esse processo, possibilita que a competência seja colocada em discussão.

Todos os indivíduos podem tornar-se competentes em informação. A competência em informação é um pré-requisito para a aprendizagem contínua, e é comum a todos os ambientes de aprendizagem e a todos os níveis educacionais. As habilidades propostas pela competência em informação devem iniciar nos primeiros anos de escola e se prolongar por toda a vida, em crescentes níveis de autonomia, levando ao aprender a aprender (CONEGLIAN; SANTOS; CASARIN, 2010, p. 259).

Hatschbach e Olinto (2008), em artigo que trata da evolução da competência em informação e das pesquisas na área, apontam que os estudos sobre o tema têm sido 
desenvolvidos principalmente no ambiente escolar. Isso pode ser um indicador de que a área educacional está atenta à importância do tema.

Ao entender o professor e o bibliotecário como agentes determinantes para a consolidação do movimento na escola, percebe-se que não basta teorizar sobre a importância da conscientização acerca do tema, mas oferecer capacitação a esses profissionais para que se tornem letrados informacionalmente e, consequentemente, aptos à formação de outrem. Tal capacitação dificilmente será completa em um curso de graduação, por isso a necessidade da busca pela formação continuada, na perspectiva do aprendizado ao longo da vida.

Sendo assim a pesquisa destina-se a compreender quais são os elementos que um curso de especialização lato sensu em Letramento Informacional deve ter para que possa contribuir para o desenvolvimento da competência em informação de professores e bibliotecários. Para tanto, buscou-se a partir do estudo de caso do curso de especialização "Letramento Informacional: educação para a informação" (CELI), responder à seguinte questão problema:

Quais são os elementos necessários a um curso de formação continuada em Letramento Informacional na modalidade EAD, para desenvolver a competência em informação de professores e bibliotecários?

\subsection{OBJETIVOS DA PESQUISA}

\subsubsection{Objetivo Geral}

Analisar os elementos do curso de especialização: Letramento Informacional educação para a informação (CELI) que podem impactar no desenvolvimento da competência em informação de professores e bibliotecários. 


\subsubsection{Objetivos Específicos}

- Identificar a competência em informação dos participantes do CELI a partir das atividades desenvolvidas no curso;

- Descrever a estrutura e os elementos que compõem o curso;

- Identificar a percepção dos participantes a respeito do curso;

- Definir diretrizes para a formação continuada em letramento informacional na modalidade EAD.

\subsection{JUSTIFICATIVA}

A presente pesquisa surgiu a partir de indagações a respeito da capacitação de professores e bibliotecários para atuar no desenvolvimento da competência em informação. À partir da percepção da pesquisadora, que atuou como professora e tutora em cursos presenciais e à distância promovidos pela Universidade Federal de Goiás (UFG), foi possível identificar falhas no entendimento e na prática de professores e de bibliotecários nas atividades de letramento informacional.

Por meio da atuação como docente do curso de Biblioteconomia, surgiu o contato com a EAD e o interesse em pesquisar a estrutura dos cursos oferecidos nessa modalidade para o desenvolvimento do letramento informacional de professores e bibliotecários. Os esforços empreendidos por um grupo de professores do curso de Biblioteconomia da UFG, no qual me incluo, levaram à concepção do Curso de Especialização em Letramento Informacional': a educação para a informação (CELI), ofertado na modalidade a distância com financiamento da Coordenação de Aperfeiçoamento de Pessoal de Nível Superior (CAPES) em parceria com a Universidade Aberta do Brasil (UAB). O curso foi voltado para professores e bibliotecários com o propósito de capacitá-los na busca, seleção e uso da informação,

\footnotetext{
${ }^{1}$ Informações sobre o curso podem ser encontradas no endereço eletrônico: http://celi.ciar.ufg.br/
} 
levando em consideração os aspectos técnicos, estéticos, éticos e políticos envolvidos no processo. O referido curso serviu de base empírica para a pesquisa.

Os rumos do estudo foram definidos pela necessidade de entender o papel fundamental dos professores e bibliotecários na consolidação do movimento, pois compreende-se a dificuldade de pensar em uma sociedade capaz de exercer a cidadania por meio do empoderamento permitido pelo conhecimento, sem passar por esses profissionais. E é claro, se estes não estiverem capacitados, haverá dificuldades para consolidar o movimento.

As pesquisas referentes ao tema e realizadas no Brasil tem centrado principalmente, na biblioteca, na formação do bibliotecário e nos diversos grupos de estudantes. Observa-se que há poucas discussões e reflexões acerca do papel do professor nesse processo. Na maioria das vezes, pressupõe-se que a competência deve ser trabalhada na escola por professores e bibliotecários, mas raramente menciona-se que tipo de formação específica esses profissionais precisam ter para estarem aptos a trabalhar com os estudantes.

Os estudos de Cruz (2008), Gasque e Tescarolo (2004), Vitorino (2008), Vitorino e Orelo (2012), Fialho (2004) e Coneglian (2013), indicam a importância dos docentes e também dos bibliotecários no desenvolvimento da competência em informação dos estudantes, mas nenhum deles tem o foco na formação continuada desses profissionais. Neste sentido, a presente pesquisa visa contribuir com a literatura da área, agregando novos conhecimentos e discussões sobre esse tema tão relevante para a Ciência da Informação e áreas afins.

Com as mudanças ocorridas na sociedade, em que as tecnologias de informação e comunicação possibilitam o acesso e a recuperação de um volume cada vez maior de informação disponibilizada em diversos suportes, as noções de limite, tempo e espaço vão sendo substituídas. Contudo, um dos fatores cruciais dessa nova era não está 
diretamente centrado na tecnologia, mas sim na produção e reprodução de conteúdos, sem a observância de alguns critérios, como a ética, por exemplo.

Por isso, a educação tem um papel fundamental: o de capacitar o indivíduo a desenvolver competências e habilidades que o possibilitem se posicionar criticamente em relação às informações a que é submetido. Mais ainda, aprender a usar a informação para desenvolver a cidadania.

Vitorino e Piantola $(2009,2011)$ abordaram a competência em informação em uma perspectiva multidimensional que contempla quatro aspectos que devem ser vistos como partes de um todo: ética, estética, técnica e política. Isso possibilita um novo olhar sobre a forma de perceber a competência e serviu como marco teórico e referencial para a pesquisa e para o curso CELI, objeto de estudo. Para os objetivos do trabalho, então, foi analisado como o CELI, desenvolvido a partir desse eixo teórico, estruturouse a fim de possibilitar o desenvolvimento de competência em informação dos participantes.

A revisão teórica da tese divide-se em quatro capítulos: o capítulo dois denomina-se Sociedade da Informação/Aprendizagem e implicações, que discute conceitos de cidadania, aprendizagem, acesso e uso da informação na sociedade contemporânea, o que está diretamente relacionado ao aspecto político da competência em informação; o capítulo três trata da Competência em Informação propriamente, conceitos, relações com o Letramento Informacional, fundamentos e aplicação prática; o capítulo quatro aborda a questão da Educação para a Competência e a Formação de Professores e Bibliotecários, tratando de questões como o aprendizado ao longo da vida, formação continuada e a importância da pesquisa para a produção de conhecimento; o capítulo cinco aborda a Educação a Distância, surgimento, evolução e importância como instrumento de capacitação e formação continuada; em seguida apresenta-se o percurso metodológico adotado no estudo, em que é possível entender o modelo conceitual e a abordagem utilizada e por último a discussão dos resultados, conclusões e sugestões para pesquisas futuras. Boa leitura! 


\section{CAPÍTULO 2}

\section{SOCIEDADE DA INFORMAÇÃOIAPRENDIZAGEM E IMPLICAÇÕES}

A sociedade atual passa por diversas modificações, principalmente no que diz respeito às Tecnologias de Informação e Comunicação (TICs). Devido ao impacto provocado pelas mesmas, recebeu o nome de Sociedade da Informação, definida como aquela que possui economia globalizada, pautada no capitalismo e que tem na informação o maior potencial de crescimento e competitividade. Hoje, falamos em Sociedade da Aprendizagem, na qual valoriza-se, principalmente, o aprendizado ao longo da vida e a educação. Tal sociedade apenas se concretiza quando a população possui recursos para se portar criticamente diante das informações que recebe, e mais, promover a cidadania a partir da aplicação destas. Neste capítulo abordamos as bases da sociedade da informação, a evolução para sociedade da aprendizagem, as relações entre conhecimento, educação e cidadania e o impacto das TICs no aprendizado.

\subsection{A INFORMAÇÃO}

A informação possui diversos conceitos, que podem variar de acordo com a área do conhecimento e propósitos. A mera existência da informação não implica em conhecimento, pois para que este seja produzido, é fundamental considerar a capacidade de interpretação e reflexão do indivíduo (CRUZ, 2008).

A informação, na sociedade contemporânea, é considerada mercadoria que proporciona vantagens competitivas e promove o desenvolvimento de organizações, nações e indivíduos e, por tal motivo, deve ser organizada e disponibilizada com qualidade $^{2}$. Segundo Vitorino e Piantola (2011, p.101), "a informação nunca é neutra, pois encerra sempre componentes pessoais, sociais, culturais e/ou ideológicos, os

\footnotetext{
${ }^{2}$ Apesar de não haver consenso a respeito do que seria informação de qualidade, a Ciência da Informação tem se dedicado a estudar indicadores para aferir a qualidade da informação. Portanto, nessa pesquisa adotaremos o conceito de que uma informação de qualidade é aquela que possui atributos tais como abrangência, acessibilidade, atualidade, confiabilidade, objetividade, precisão e validade (OLETO, 2006) e que, além disso, atenda às necessidades de informação do usuário.
} 
quais precisam ser adequadamente identificados e interpretados, a fim de que a partir dela se possam produzir conhecimento e benefícios aos indivíduos e à sociedade".

Dependente do contexto e dos demais fatores mencionados pelas autoras para que de fato possa considerar-se a informação como tal, percebe-se que quando falamos em informação uma pergunta fundamental deveria ser feita, informação para quem? O usuário é quem determina (ou deveria determinar) o que é necessário em uma informação em termos de conteúdo, linguagem e formato para que a mesma cumpra o papel a que se destina, o de informar. Do contrário ela será apenas mais um dado não contextualizado (DAVENPORT, 1998). A possibilidade de dotar um conjunto de dados de sentido compreendendo-os e visualizando os seus propósitos é o que os transforma em informação, e a reflexão e o pensamento crítico é o que permite a conversão da informação em conhecimento, saber.

Outra questão que se coloca é: informação para quê? As necessidades de informação mudam de acordo com o contexto e papel assumido pelo indivíduo em dado momento, o que determinará os propósitos da busca. Diante disso, o usuário não pode mais ser visto como aquele que tem sempre as mesmas demandas. Para Le Coadic (2004), apesar de todas as mudanças sociais, o objetivo da informação permanece o mesmo: a apreensão dos significados e transformação em conhecimento.

Dentre os problemas relacionados à informação, talvez o maior deles seja o excesso, pois há tantas informações disponíveis e não organizadas na rede que tornase difícil identificar quais conteúdos são confiáveis e relevantes em uma busca. Em consequência disso, também deveria estar claro que a educação e a capacitação dos indivíduos para o manejo adequado da informação é uma emergência, pois uma premissa para atuar nessa sociedade é ter competência para avaliar os conteúdos informacionais a que estamos sujeitos para ser capaz de transformar informação em conhecimento. 
Ao referir-se especificamente à educação, Cruz (2008) evidenciou que essa avalanche informacional pode dificultar a aprendizagem do estudante, pois não há tempo para processar os conteúdos e consequentemente avaliá-los, o que o deixa na superficialidade. Na mesma linha, Demo (2000, p.39) destaca que "selecionamos o que é possível captar, sem falar que preferimos o que nos interessa". Ou seja, os interesses pessoais vão determinar os conteúdos a serem explorados pelos indivíduos com mais entusiasmo diante da impossibilidade de absorver tudo aquilo que está à disposição.

A informação é construída socialmente por pessoas em contextos e condições socioculturais específicos, a partir da percepção de cada um, dos pontos de vista distintos, o que só é possível através da reflexão. A reflexão e o olhar crítico nos fazem perceber e reconhecer que existem outros pontos de vista além do nosso (RIOS, 2011), o que enriquece o nosso estoque de conhecimentos e amplia a nossa visão de mundo.

Demo (2000), em texto que trata da ambivalência da sociedade da informação, destaca que a informação possui dois papéis, o de informar e como consequência o de desinformar, podendo ser considerada como duas faces da mesma moeda advindas do capitalismo e interesses unilaterais, leia-se mercadológicos. $\mathrm{O}$ autor conclui que:

A informação não pode ser receita pronta, mas o desafio de a criar, mudar, refazer. O risco de manipulação é intrínseco, mas é no risco que podemos reduzir a manipulação. A sociedade da informação informa bem menos do que se imagina, assim como a globalização engloba as pessoas e povos bem menos do que se pretende. Na sociedade da mercadoria, mercadoria vem antes (DEMO, 2000, p.41).

Como a informação constitui-se elemento de poder, quem consegue não apenas acessá-la, mas transformá-la em conhecimento/ação, tem mais chances de tomar decisões adequadas e resolver problemas cotidianos, o que permitiria ao cidadão maior autonomia. Porém, como há interesses econômicos e políticos por detrás da informação que é disponibilizada/veiculada, não se informa como deveria, o que torna a sociedade bastante desinformada e manipulada pelas mídias de massa que geralmente emitem opiniões tendenciosas e parciais. 
Demo (2000, p.40) elenca cinco fatores que contribuem para a desinformação da sociedade, quais sejam:

- Chega à sociedade, tendencialmente, informação residual, ou porque há imposição de informação oficial, ou porque se entope atabalhoadamente;

- A informação está dividida em classes: superior e inferior, que varia de acordo com o poder aquisitivo de cada um;

- Informação imbecilizante: aquela que explora as futilidades da mídia;

- A mídia está muito distante da função pública, pois os interesses comerciais estão acima dos sociais;

- Por último, o acesso elitista aos meios de acessar a informação.

Os fatores colocados pelo autor demonstram que o indivíduo precisa desenvolver habilidades e competências que o permita acessar, selecionar, analisar e usar a informação (etapas do comportamento informacional) de maneira adequada. Isso é um pré-requisito básico para atuar nesta sociedade, por isso é fundamental que tais conteúdos sejam trabalhados na escola.

Para Belluzzo (2005), a desinformação pode ser considerada a razão de muitos problemas sociais, sendo o uso racional do conhecimento fator competitivo que pode levar a sociedade ao desenvolvimento. Tal desenvolvimento passa necessariamente pela adoção de políticas e estratégias que possibilitem ao indivíduo estudar, conhecer e aplicar os conhecimentos adquiridos no cotidiano, permitindo um aprendizado contínuo, ou seja, saber lidar corretamente com a informação passa a ser questão decisiva e de responsabilidade social.

A mudança de paradigma que marca a sociedade, passando do acesso à informação para a produção de conhecimento, envolve maior capacidade crítica dos sujeitos em relação aos critérios como confiabilidade, pertinência e relevância das informações. Envolve também preparo para lidar com as novas tecnologias, o que no caso específico do Brasil é um desafio enorme (BELLUZZO, 2005). 
Santos e Carvalho (2009) complementam a discussão:

No caso do Brasil, o uso da informação deve estar atrelado à melhoria da qualidade educacional e aumento da alfabetização da população. Com um aumento da alfabetização e um melhor uso da informação, utilizando as tecnologias da informação e comunicação como suporte, pode-se dizer que de fato o Brasil estará em uma "sociedade da informação". Mas o que se observa atualmente é a criação de mais um fator de exclusão social, pois a simples conectividade, ou acesso, as TIC não garante ao cidadão o uso da informação. (SANTOS; CARVALHO, 2009, p.52).

Uma sociedade que pode ser classificada como "da informação" no Brasil tem inúmeros desafios como podemos observar nos discursos dos autores citados. O maior deles é o investimento em educação de qualidade, visto que apenas a tecnologia e o acesso à internet não possibilitam a ninguém o uso consciente da informação. As TICs são ferramentas, suportes e geralmente são supervalorizadas como a solução de todos os problemas informacionais, o que é uma falácia, uma vez que "o fato de ter acesso à tecnologia não significa ter acesso ao conhecimento" (LECARDELLI; PRADO, 2006, p.22).

Caminhamos, então, para um ideal de sociedade que seja capaz de realizar a gestão da informação efetiva, em que gerir informação seria concluir as etapas do ciclo informacional desde o momento da busca (a partir de uma necessidade previamente identificada) até o momento da tomada de decisão realizada a partir da informação selecionada. "A gestão da informação é o grande desafio dos tempos atuais, constituindo-se no próximo estágio de 'alfabetização' do homem" (BELLUZZO, 2004, p.22). Só é capaz de realizar a gestão da informação de forma efetiva, indivíduos e organizações que possuam competência em informação, logo esta passa a ser condição sine qua non para atuação consciente em sociedade.

\subsection{CONHECIMENTO, EDUCAÇÃO E CIDADANIA NA SOCIEDADE DA APRENDIZAGEM}

Entender a importância da informação e o poder exercido pelo conhecimento em nossa sociedade é fundamental para propor mecanismos que permitam aos indivíduos 
o exercício da cidadania. Um desses mecanismos, objeto de estudo dessa tese, é a competência em informação.

Diante do volume cada vez maior de informação disponibilizada e da facilidade que a internet proporciona para acessá-las, o desenvolvimento da competência em informação por meio do letramento informacional, pode ser considerado instrumento de capacitação/educação das pessoas. Possibilita-as ampliar conhecimentos, preparar-se para o mercado de trabalho, permite análise crítica dos conteúdos a que somos submetidos e, em consequência disso, maior preparo para atuar de forma partícipe em sociedade.

Hoje, por excesso de informações ou por necessidade de acompanhar as mudanças tecnológicas, vivemos em um paradoxo. De acordo com Pozo (2004), nunca uma sociedade dedicou-se tanto ao aprendizado contínuo e a aprender várias coisas ao mesmo tempo, mas em contrapartida há cada vez mais pessoas com dificuldades de aprender o que é exigido pela sociedade. O autor, então, define a sociedade da aprendizagem como:

Uma sociedade na qual aprender constitui não apenas uma exigência social crescente - que conduz ao seguinte paradoxo: cada vez se aprende mais e cada vez se fracassa mais na tentativa de aprender -, como também uma via indispensável para o desenvolvimento pessoal, cultural e mesmo econômico dos cidadãos (POZO, 2004, p.34).

A sociedade da aprendizagem seria a evolução da sociedade da informação, baseando-se na educação continuada e no aprendizado ao longo da vida. Uma sociedade que não se restrinja à utilização dos recursos informacionais a partir do acesso à tecnologia, mas que esteja apta a transformar informação em conhecimento.

Nesta sociedade, a informação é fundamental para proporcionar às pessoas condições de tomar decisões de maneira adequada. Nesse sentido, Santos e Carvalho (2009, p.52) apontam que "se o cidadão não tiver consciência de que seu papel pode ser transformador, se não souber usar as informações que possuem para mudar seu 
entorno, o uso da informação será vazio". Ou seja, é preciso pensar em formas de possibilitar que o cidadão consiga se informar adequadamente e usar as informações que recebe em benefício próprio e também coletivo.

A cidadania é exercida pelos integrantes de uma sociedade quando eles possuem consciência dos direitos (e consequentemente dispõem de instrumentos para reivindicá-los) e dos deveres. Isso perpassa pelo acesso à informação de qualidade e consequentemente pela capacidade de usar tais informações corretamente, o que demandaria a competência em informação. Se o cidadão precisar de informação para sanar uma dificuldade ou para a tomada de decisão, terá meios para obtê-la, pois estará capacitado para tanto. Sendo assim a $\mathrm{Cl}$ exerce um papel social, visto que o indivíduo competente em informação participa ativamente da construção do conhecimento e da sociedade (CONEGLIAN, SANTOS, CASARIN, 2010).

Ainda em relação à cidadania, para a efetivação na sociedade, dependemos de alguns fatores como "uma ampla disseminação e circulação da informação e, ainda, de um processo comunicativo de discussão crítica sobre as diferentes questões relativas à construção de uma sociedade mais justa e, portanto, com maiores oportunidades para todos os cidadãos" (SILVA et al., 2005, p.31). Isso significa que várias áreas do conhecimento devem se integrar para discutir e propor soluções para os problemas informacionais que a sociedade tem enfrentado e os que ainda estão por vir.

Targino (1991, p.155) define a relação entre informação e cidadania apontando que não existe exercício dessa sem informação, pois "a informação é um bem comum, que pode e deve atuar como fator de integração, democratização, igualdade, cidadania, libertação, dignidade pessoal". Assim como vários direitos básicos assegurados à população através da Constituição Federal, o direito à informação também deveria ser prioridade, afinal o acesso à informação de qualidade no momento adequado pode minimizar diversos problemas cotidianos. 
É fundamental destacar que o acesso material à informação nada garante, por isso a competência para transformá-la em conhecimento que permita intervenção na realidade é tão importante. Vitorino e Piantola (2011, p.101) corroboram com esta perspectiva, quando afirmam que:

A informação é elemento constituinte da cultura de um grupo, é, em sua essência, condição de permanência e instrumento de mudança. Por isso, o acesso à informação e ao conhecimento é tido como componente fundamental para o exercício da cidadania no contexto democrático. Assume-se, porém, que a cidadania não se constrói apenas a partir do acesso material à informação, mas deve compreender também a capacidade de interpretação da realidade e de construção de significados pelos indivíduos (VITORINO; PIANTOLA, 2011, p. 101).

Em levantamento ${ }^{3}$ realizado pela Organização das Nações Unidas (ONU) sobre o Índice de Desenvolvimento Humano (IDH) no mundo referente ao ano de 2014 e publicado em 2015, percebemos que dentre os fatores levados em consideração para determinar o índice está a educação. Tanto para crianças em idade escolar como para adultos acima de 25 anos e idosos. Isso demonstra a importância da educação para que as pessoas e países se desenvolvam.

Na tabela 1, na primeira coluna, há a posição do país no ranking em seguida o nome do país, na terceira o IDH de 2014, na quarta a expectativa de vida ao nascer, na quinta a média de anos de escolaridade recebidos por adultos acima de 25 anos e idosos, a sexta coluna indica a quantidade de anos de escolaridade que uma criança entrando na escola em idade regular terá o direito a receber e na última coluna está o rendimento nacional bruto per capita. A tabela foi adaptada da original e contém a indicação dos cinco países com maior IDH e a posição do Brasil.

\footnotetext{
${ }^{3}$ Documento disponível em: < http://www.pnud.org.br/hdr/Relatorios-Desenvolvimento-HumanoGlobais.aspx?indiceAccordion=2\&li=li_RDHGlobais\#2015>
} 
Tabela 1 - Índice de desenvolvimento humano e seus componentes

\begin{tabular}{|l|l|l|l|l|l|l|}
\hline $\begin{array}{l}\text { Posição no } \\
\text { ranking }\end{array}$ & País & $\begin{array}{l}\text { IDH } \\
2014\end{array}$ & $\begin{array}{l}\text { Esperança de } \\
\text { vida à } \\
\text { nascença } \\
\text { (anos) }\end{array}$ & $\begin{array}{l}\text { Anos de } \\
\text { escolaridade } \\
\text { esperados }\end{array}$ & $\begin{array}{l}\text { Média de } \\
\text { anos } \\
\text { escolaridade }\end{array}$ & $\begin{array}{l}\text { Rendimento } \\
\text { nacional } \\
\text { per } \\
\text { (dólar) }\end{array}$ \\
\hline 1 & Noruega & 0,944 & 81,6 & 17,5 & 12,6 & 64.992 \\
\hline 2 & Austrália & 0,935 & 82,4 & 20,2 & 13,0 & 42.261 \\
\hline 3 & Suíça & 0,930 & 83,0 & 15,8 & 12,8 & 56.431 \\
\hline 4 & Dinamarca & 0,923 & 80,2 & 18,7 & 12,7 & 44.025 \\
\hline 5 & Países baixos & 0,922 & 81,6 & 17,9 & 11,9 & 45.435 \\
\hline 75 & Brasil & 0,755 & 74,5 & 15,2 & 7,7 & 15.175 \\
\hline
\end{tabular}

Fonte: Elaboração própria baseada no documento da ONU (2015).

Os dados demonstram diferenças significativas em relação à educação de adultos e idosos. Na Noruega, primeiro país do ranking, a média de anos de escolaridade de um adulto é 12,6 e no Brasil 7,7, ou seja, é uma situação delicada que merece atenção do governo em relação aos investimentos em políticas públicas de acesso à educação para adultos, a fim de possibilitar a essas pessoas condições de melhoria de vida. Quanto mais instruída e educada é uma população, maiores as chances de exercer a cidadania. Os desafios são inúmeros, mas não podemos deixar de persistir na luta por uma sociedade mais justa e igualitária.

Dudziak (2008) propõe reflexão a respeito do assunto ao destacar alguns aspectos a serem observados para alcançar um patamar mais elevado de desenvolvimento:

Ponderemos os desafios enfrentados por todas as nações, inclusive o Brasil: a busca por um desenvolvimento pleno; a necessidade de se construir uma sociedade equânime e inclusiva; a priorização do acesso democrático à informação, baseada em uma educação que conduz à formação de indivíduos emancipados; o direito à comunicação e ao exercício integral da cidadania; a busca pelo desenvolvimento sustentável como fator de promoção da qualidade de vida das populações, o avanço econômico e a preservação do meio ambiente (DUDZIAK, 2008, p. 42).

Os pontos destacados pela autora indicam que a informação é elemento fundamental para vários aspectos do desenvolvimento social. Isso por envolver economia, política, sustentabilidade e, sobretudo educação que permita a emancipação dos sujeitos. 
Em relação à educação, o aprendizado contínuo está relacionado diretamente ao letramento informacional. Para que seja possível a aprendizagem constante é fundamental que a educação esteja voltada à autonomia do indivíduo, orientando-o a buscar pelo conhecimento para sanar as dúvidas e permitir o crescimento pessoal e profissional. Nessa vertente, a EAD se transformou em instrumento fundamental para que as pessoas possam se capacitar, pois a tecnologia permite estudar sem sair de casa, além do mais é uma forma de levar a educação a lugares com pouca estrutura e acesso a cursos de qualidade oferecidos por universidades renomadas do Brasil e do mundo.

A necessidade percebida atualmente em relação ao aprendizado contínuo e ao longo da vida (lifelong learning) coloca a educação no centro do desenvolvimento da sociedade. Por isso, a aquisição da competência para acessar e usar a informação constitui-se elemento essencial na educação contemporânea (BELLUZZO, KERBAUY, 2004).

Fica claro a importância do aprendizado para a promoção de mudanças no perfil dos cidadãos, ou seja, a informação produz conhecimento, que proporciona o aprendizado e conduz o indivíduo à reflexão crítica. Para ser cidadão autônomo nesta sociedade não basta dominar os recursos tecnológicos ou ser letrado digitalmente. Saber utilizar e produzir conteúdos digitais não garante a competência para avaliar o que é realmente relevante, confiável e útil dentre as inúmeras informações disponíveis. É preciso ir além, pensar no letramento informacional junto ao digital, pois esta é uma condição fundamental para o desenvolvimento da competência. "A relação entre qualidade e quantidade de informação é, sem dúvida, um dos 'calcanhares de aquiles' desta sociedade. Por isso, o grande desafio está em transformar o imenso volume e o intenso fluxo de informações em conhecimento" (CRUZ, 2008, p.1024).

Observamos com o advento da internet e o avanço das TICs que as pessoas passaram a ter dificuldades em discernir o que é de qualidade ou não na rede, pois o volume de dados e informações disponibilizados é imenso. É fundamental ter 
conhecimento sobre as fontes e as estratégias de busca para que a recuperação da informação se torne mais precisa, minimizando assim o tempo despendido nas buscas e aumentando a qualidade do que é recuperado. Sem esse conhecimento, a internet se torna, cada vez mais, um mar de informações em que o naufrágio parece inevitável.

Dupas (2001) demonstra preocupação quanto à ideia admitida pela sociedade de que as TIC são ferramentas libertadoras, sem haver, contudo, uma reflexão sobre a manipulação e alienação que elas podem causar ao indivíduo. O autor defende que "a tecnologia pode e deve se submeter a uma ética que seja libertadora a fim de contemplar o bem-estar de toda a sociedade, presente e futura, e não apenas colocarse a serviço de minorias ou atender necessidades imediatas" (DUPAS, 2001, p.18).

Hoje não basta ter acesso, pois o mesmo foi facilitado com o advento das tecnologias, mas sim saber identificar o que é relevante. Para constituirmos uma sociedade do aprendizado é preciso, principalmente, buscar educação de qualidade, que possibilite o contato com a informação em diferentes suportes e desenvolva a capacidade individual de gerir as informações utilizando-se de todas as etapas do processo: análise, seleção, tratamento, armazenamento e uso da informação.

A sociedade da aprendizagem para que se concretize plenamente depende de pessoas letradas e competentes. A grande questão a ser enfrentada no Brasil é tornar isso possível considerando que os indivíduos têm acesso precário à educação, à saúde, à segurança e outras necessidades básicas. Assim, questionamos como oferecer ferramentas que os capacitem ao uso correto da informação, como a informação pode ser usada para mudar essa condição e trazer autonomia na tomada de decisão em quaisquer circunstâncias. Esses são desafios que nos são colocados e acreditamos que é na escola que tudo deve começar. 


\section{CAPÍTULO 3}

\section{COMPETÊNCIA EM INFORMAÇÃO E LETRAMENTO INFORMACIONAL}

Neste capítulo abordamos os princípios teórico-conceituais da competência em informação e do letramento informacional, origem e aplicação prática. Porém, não é objetivo discutir as diversas traduções para o termo original em inglês Information Literacy, nem tratar da evolução, por isso ter sido feito de forma detalhada em trabalhos como o de Dudziak (2003), Campello (2003), Lecardelli e Prado (2006), Hatschbach e Olinto (2008), Gasque (2008), dentre outros.

\subsection{FUNDAMENTOS TEÓRICOS DA COMPETÊNCIA EM INFORMAÇÃO E LETRAMENTO INFORMACIONAL}

A competência em informação surge no Brasil no início de 2000, mas, a nomenclatura ainda suscita discussões. Alguns autores utilizam o termo competência em informação, competência informacional, outros habilidades informacionais, e há os que preferem utilizá-lo no original em inglês, information literacy, pois não há consenso sobre qual termo se deve adotar. Ao se pensar em competência em informação, compreendemos que competência diz respeito à capacidade de mobilizar atitudes e conhecimentos para a ação, ou seja, está relacionada à aplicação prática de conhecimentos adquiridos, fundamental para todos os indivíduos e profissionais, especialmente para professores e bibliotecários.

Em linhas gerais, a competência pode ser considerada como conjunto de habilidades desenvolvidas pelo indivíduo que o permite agir em determinada situação ou contexto, a partir dos conhecimentos adquiridos previamente. Está relacionada à atitude e à prática, ou seja, por mais que o indivíduo tenha conhecimento a respeito de algo, ele não necessariamente terá competência, a menos que transforme os conhecimentos em ação. Miranda (2004, p.116) reitera que "o conhecimento existe somente no ser humano e somente pode ser mobilizado pelas pessoas. O mesmo acontece com a competência". 
O conhecimento é ativo fundamental para o desenvolvimento das nações, e para que as organizações e as pessoas consigam se posicionar diante das mais diversas questões, é preciso que desenvolvam competências que possibilitem aplicá-los. Apesar de ser um conceito oriundo da área empresarial, Gasque (2012) apresenta definição de competência aplicada ao contexto educacional.

\footnotetext{
O conceito de competência surge no campo empresarial e financeiro com o objetivo de buscar, por meio de programas de 'capacitação de recursos humanos', 'reengenharia' ou 'qualidade total', alternativas para melhorar a produtividade e a competitividade no trabalho humano, em decorrência do processo de substituição tecnológica que produz novas formas de organização do trabalho. No âmbito educativo, a ideia de transposição dos conteúdos do 'mundo do trabalho para o currículo escolar' situa-se no cerne do conceito de competência, com a intenção de superar a lacuna existente entre os conhecimentos propiciados pela escola e aqueles requeridos pelo mercado. Assim, a noção subjacente ao conceito de competência é a aplicação prática do conhecimento (GASQUE, 2012, p.33).
}

A competência em informação pode ser compreendida como produto do processo do letramento informacional (information literacy), movimento que começou nos Estados Unidos em meados da década de 1970 e passou a ser estudado no Brasil a partir do ano 2000, por meio de trabalho desenvolvido por Caregnato (CAMPELLO, 2003; BELLUZZO, 2004; DUDZIAK, 2008; VITORINO e PIANTOLA, 2009), o que demonstra ser tema recente. Porém, apesar do pouco tempo, a temática tem crescido muito na área de Biblioteconomia e Ciência da Informação, bem como em áreas correlatas, como Administração, Psicologia e Pedagogia, demonstrando que a importância não se restringe a ambientes educacionais ou organizacionais, mas a todos os contextos, afinal, todas as pessoas necessitam de informação no cotidiano.

Dudziak (2003, p.28) define o termo information literacy como "processo contínuo de internalização de fundamentos conceituais, atitudinais e de habilidades necessário à compreensão e interação permanente com o universo informacional e sua dinâmica, de modo a proporcionar um aprendizado ao longo da vida". Segundo a autora, as bases fundamentais do conceito são o processo investigativo; o aprendizado ativo; o aprendizado independente; o pensamento crítico; o aprender a aprender e o aprendizado ao longo da vida. 
O conceito surgiu como indicação de que os bibliotecários deveriam repensar as práticas em relação ao atendimento prestado aos usuários de biblioteca, principalmente na biblioteca escolar. Muda-se da perspectiva de instrução do uso dos recursos da biblioteca para uma forma de desenvolver a autonomia dos indivíduos em todo o processo de busca, avaliação crítica e seleção das fontes de informação (CAMPELLO, 2003; CAREGNATO, 2000).

A American Library Association - ALA (2000) aponta que a information literacy constitui a base para o aprendizado ao longo da vida. É comum a todas as disciplinas, ambientes de aprendizagem e a todos os níveis de ensino. Permite ao estudante maior autonomia e a realização de pesquisas mais abrangentes, assumindo maior controle sobre a aprendizagem.

Apesar de o tema ter se tornado relevante no Brasil a partir do ano 2000 , as pesquisas na área tem crescido muito, o que é demonstrado em levantamento realizado por Santos (2011). É possível perceber a evolução do número de estudos realizados no país de 2001 até 2010, em formato de artigo de periódico, tese ou dissertação, como demonstrado na tabela abaixo.

Tabela 2 - Quantidade de publicações sobre competência em informação de 2001 a 2010

\begin{tabular}{cccc}
\hline ANO & $\begin{array}{c}\text { ARTIGO DE } \\
\text { PERIÓdICO }\end{array}$ & $\begin{array}{c}\text { TESE OU } \\
\text { DISSERTAÇÄO }\end{array}$ & $\begin{array}{c}\text { TOTAL POR } \\
\text { ANO }\end{array}$ \\
\hline Até jun. de 2010 & 3 & 0 & 3 \\
2009 & 10 & 6 & 16 \\
2008 & 12 & 5 & 17 \\
2007 & 6 & 4 & 10 \\
2006 & 13 & 0 & 13 \\
\hline 2005 & 4 & 2 & 6 \\
2004 & 2 & 1 & 3 \\
\hline 2003 & 2 & 0 & 2 \\
\hline 2002 & 0 & 1 & 1 \\
\hline 2001 & 0 & 1 & 1 \\
\hline Total & 52 & 20 & $\mathbf{7 2}$ \\
\hline
\end{tabular}

Fonte: Santos (2011, p. 47). 
Com a finalidade de atualizar os dados e também compará-los, realizamos pesquisa semelhante em janeiro de 2016. A pesquisa de teses e dissertações foi realizada no site da Biblioteca Digital Brasileira de Teses e Dissertações - BDTD/IBICT, e a busca pelos artigos foi efetuada no portal de periódicos da CAPES. Os termos utilizados em ambas as buscas foram: information literacy, letramento informacional, competência em informação e competência informacional. Cada item recuperado foi checado individualmente a fim de verificar se correspondia aos propósitos da busca. Sendo assim chegou-se ao seguinte resultado, como é possível visualizar na tabela 3.

Tabela 3- Quantidade de publicações sobre competência em informação de 2010 a 2015

\begin{tabular}{llll}
\hline ANO & $\begin{array}{c}\text { ARTIGO DE } \\
\text { PERIÓDICO }\end{array}$ & $\begin{array}{c}\text { TESE OU } \\
\text { DISSERTAÇÃO }\end{array}$ & TOTAL POR ANO \\
\hline $\mathbf{2 0 1 0}$ & 7 & 4 & 11 \\
$\mathbf{2 0 1 1}$ & 10 & 10 & 20 \\
$\mathbf{2 0 1 2}$ & 10 & 9 & 19 \\
$\mathbf{2 0 1 3}$ & 6 & 15 & 21 \\
$\mathbf{2 0 1 4}$ & 15 & 12 & 27 \\
$\mathbf{2 0 1 5}$ & 10 & 2 & 12 \\
Total & $\mathbf{5 8}$ & $\mathbf{5 2}$ & $\mathbf{1 1 0}$ \\
\hline
\end{tabular}

Fonte: elaboração própria baseada em dados do portal CAPES e BDTD (2016).

Observa-se que 2014 foi o ano com maior número de publicações sobre o tema, e que em 2013 o número de teses e dissertações foi mais que o dobro do número de artigos. Em comparação aos dados apresentados por Santos (2011) evidencia-se que nos últimos cinco anos a publicação de artigos foi maior do que nos dez anos anteriores, e a de teses e dissertações mais que dobrou. Isso indica que a temática passou a ser de maior interesse por parte dos pesquisadores.

De acordo com Belluzzo (2005, p.44), a competência em informação abrange três concepções, quais sejam:

- Digital - concepção com ênfase na tecnologia da informação e da comunicação.

- Informação propriamente dita - concepção com ênfase nos processos cognitivos. 
- Social - concepção com ênfase na inclusão social, consistindo em uma visão integrada de aprendizagem ao longo da vida e exercício de cidadania.

Os estudos sobre competência em informação podem ser realizados em diversos ambientes, com usuários de biblioteca de diferentes tipos, nas escolas e universidades, com as pessoas em contextos de busca de informação no cotidiano e em ambientes organizacionais. Os objetivos dos estudos são bastante variados.

Tradicionalmente, as pesquisas realizadas em bibliotecas tinham como objetivo principal verificar a habilidade dos usuários no uso das fontes de informação (CAREGNATO, 2000; HATSCHBACH e OLINTO, 2008). Já os que foram e são

realizados no contexto escolar geralmente têm como propósito entender como o estudante lida com as fontes de informação na realização de pesquisas e como ele se sente quando se envolve em um processo de busca. Os estudos realizados no ambiente universitário estão voltados à identificação do modo como o estudante busca e usa a informação no contexto acadêmico.

\subsection{APLICAÇÃO PRÁTICA DA COMPETÊNCIA EM INFORMAÇÃO}

A competência em informação pode ser percebida como consequência do letramento informacional, que deve ser desenvolvido durante todo o período escolar para que, ao longo da vida, o indivíduo tenha condições de tomar decisões, definir conteúdos de interesse, buscar subsídios para suprir as próprias necessidades informacionais e atuar de forma colaborativa em sociedade. Gasque (2010) destaca as diferenças conceituais entre os dois termos ao alertar para o fato de que não são sinônimos, sendo o letramento informacional um processo e a competência as habilidades desenvolvidas ao longo de tal processo, uma espécie de resultado prático.

O entendimento adotado nesta tese é o de que o letramento é uma condição para o desenvolvimento da competência, e muito do que denomina-se competência em 
informação é na verdade letramento, principalmente quando fala-se em aprendizado ao longo da vida e aprender a aprender, ou seja, são conceitos complementares.

Para Vitorino e Piantola (2009) o conceito de competência vai além da reunião de habilidades para acessar e usar a informação, sendo uma ferramenta fundamental na construção de uma sociedade livre e democrática, na qual os indivíduos estariam aptos a determinar o curso de suas vidas.

Em vista dessa concepção, percebemos que, para uma pessoa se tornar competente em informação, ela precisará não apenas desenvolver habilidades na obtenção da informação de que necessita, mas principalmente se apoderar delas, transformando-as em conhecimento. Pessoas competentes em informação, segundo Dudziak (2010, p.8), são aquelas que "estão familiarizadas com as várias mídias de informação, incluindo jornais, revistas, televisão, internet, entre outras. Sabem como o mundo da informação é estruturado, como acessar as redes formais e informais de informação, conhecem as estruturas de comunicação".

Para implementar programas de competência na escola ou em outros ambientes, um fator fundamental e que, portanto, deve ser levado em consideração é o contexto no qual o indivíduo está inserido, tanto cultural, educacional, social quanto econômico. É preciso conhecer a realidade do grupo e as particularidades nas formas de buscar, tratar e usar a informação.

A função de mediar esse processo de capacitação e educação de pessoas a utilizarem a informação corretamente tem sido exercida principalmente pelos bibliotecários. É da natureza da profissão auxiliar usuários a recuperar a informação que necessitam, porém os professores tem papel crucial, o de promover a educação para a informação, garantindo assim o ingresso das pessoas na sociedade da informação, como sugere Le Coadic (2004). O autor acredita que para dominar a informação é preciso aprender a se informar, a informar outrem e a pesquisar, e para tanto propõe que seja criada uma disciplina voltada ao desenvolvimento dessas 
habilidades desde o ensino básico até a universidade. Tais habilidades são apontadas por Fialho $(2004$, p.60) sendo elas: aprender a aprender, usar e comunicar a informação, avaliar criticamente a informação segundo critérios de relevância, objetividade, pertinência, lógica e ética, incorporando as informações ao sistema de valores e conhecimentos.

Vale destacar que na sociedade da aprendizagem é fundamental que os indivíduos desenvolvam habilidades e atitudes pró-ativas em relação à informação se quiserem efetivamente ser incluídos. Belluzzo (2004) acredita que um dos maiores desafios diz respeito à compreensão e internalização dos conteúdos, pois só há mudança de comportamento se houver assimilação.

A competência em informação envolve o desenvolvimento de algumas competências específicas, de acordo com Pozo (2004, não paginado) são elas:

- Competência para localizar informação relevante;

- Competências para a aquisição de informação;

- Competências para a interpretação da informação;

- Competências para a análise da informação;

- Competências para a compreensão da informação;

- Competências para a comunicação da informação.

Cada competência faz parte de um ciclo que é desencadeado por um comportamento de busca que se inicia quando o sujeito sente a necessidade de uma informação para solucionar problema ou tomar decisão. Sendo assim, ele precisa saber localizar a informação, conhecer as fontes, manusear os mecanismos de busca e catálogos de bibliotecas; deve saber como adquirir a informação desejada, se é gratuita, se está disponível; ter competência para interpretar e contextualizar a informação, checar a veracidade da fonte e relacionar com outras informações coletadas; em seguida é preciso analisar se a informação obtida atende aos propósitos iniciais da busca. É fundamental ter capacidade crítica para que possa assimilar, 
compreender a informação, internalizá-la a fim de comunicá-la, transformando-a em um novo conhecimento, produto ou serviço.

Na mesma linha de pensamento, Dudziak (2011) acredita que a competência em informação é um ciclo composto de sete etapas. No primeiro momento o indivíduo percebe a necessidade de informação, há então ausência no estoque de conhecimento a respeito daquilo que precisa. Em seguida, é preciso definir a informação que poderá sanar a dúvida. O terceiro passo diz respeito à localização das fontes de informação e saber onde encontrará as respostas. O passo seguinte seria analisar as informações obtidas a partir de critérios de relevância e pertinência e, para tanto, é preciso ter conhecimento prévio a respeito desses critérios e capacidade de interpretação. O quinto passo é o uso da informação efetivamente para a solução de problemas e a tomada de decisão. O sexto passo está relacionado à transformação da informação em conhecimento novo, de modo que esta possa ser comunicada em outros formatos. $O$ sétimo e último passo é o registro da informação utilizada e o arquivamento para uso futuro. As sete etapas estão representadas na figura 1 a seguir.

Figura 1 - Ciclo da Competência em informação

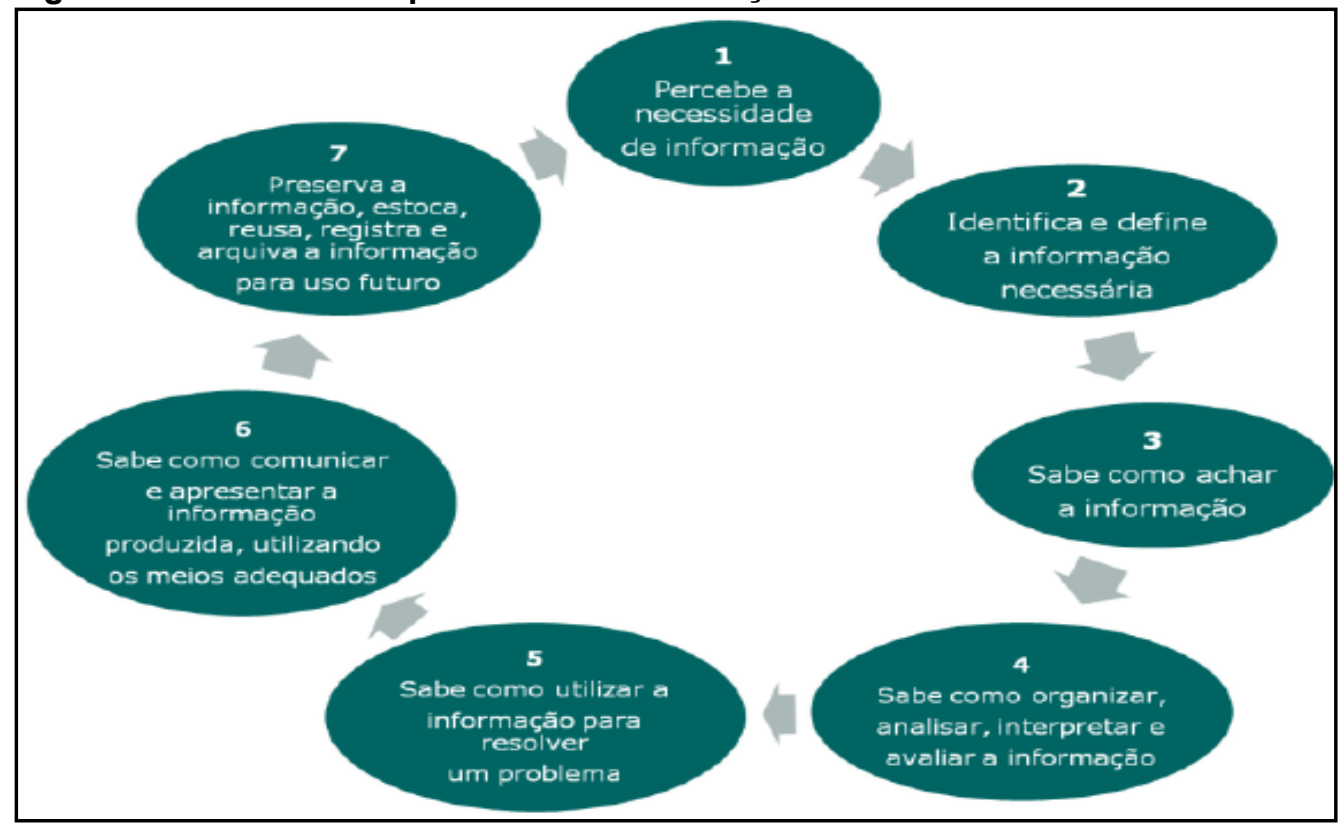

Fonte: Dudziak (2011, p.176). 
É importante reforçar que apesar de a competência pressupor tais etapas, o indivíduo competente não se restringe a elas, é preciso que além de cumprir o ciclo seja capaz de atuar em sociedade a partir dos conhecimentos que adquirir. As dificuldades encontradas pelos profissionais que atuam na área de educação para trabalhar a $\mathrm{Cl}$ parecem estar relacionadas principalmente à aplicação prática. Primeiro porque é preciso ter competência em informação para capacitar outrem - e nem sempre os bibliotecários e professores estão aptos nesse sentido - e segundo porque, para que se desenvolva a competência para uso da informação, é preciso ser letrado, o que no Brasil não é realidade, pois os investimentos em educação e cultura são escassos.

A formação desses profissionais deve estar de acordo com as demandas atuais, que requerem o domínio não apenas técnico do trabalho com a informação, mas o intelectual, que está diretamente relacionado à capacidade reflexiva. Ademais, a atuação conjunta entre professor e bibliotecário é fundamental para a consolidação da competência em informação e exige trabalho integrado entre ambos, que pode ser idealizado a partir da pesquisa escolar, pois esta constitui-se como instrumento essencial para se trabalhar a competência, visto que em todas as etapas exige-se do estudante a capacidade de reflexão para a solução de problemas (BELLUZZO, 2005; CAMPELLO, 2004).

Além de profissionais capacitados, outro fator necessário ao desenvolvimento da competência é a presença da biblioteca na escola, que deve estar voltada ao atendimento dos estudantes de forma a possibilitar não apenas o acesso à informação, mas também a autonomia. Tal biblioteca precisa contar com infraestrutura física e pedagógica adequada, e isso só é possível se a mesma passar a ser vista como peça imprescindível para o aprendizado, o que na prática não acontece.

Caregnato (2000) destaca o importante papel que tradicionalmente as bibliotecas tem desempenhado ao oferecer serviços de educação de usuários no uso das fontes, realização de pesquisas e orientação física, mas reitera que à medida que as formas de acesso tem sido modificadas e aprimoradas pelo uso das tecnologias, as mesmas 
devem estar preparadas para oferecer serviços de informação de qualidade, adequados ao ambiente digital.

\subsection{DIMENSÕES DA COMPETÊNCIA EM INFORMAÇÃO}

Várias atitudes dos indivíduos em relação à informação podem ser desencadeadas sem nenhum conhecimento crítico e sim intuitivo, porém a competência em informação, quando desenvolvida adequadamente, permite que tais atitudes sejam tomadas de forma consciente e planejada, com o propósito de aperfeiçoar o uso da informação. O exercício da cidadania a partir do uso da informação, por exemplo, está relacionado à dimensão política da competência em informação que abrange outras três dimensões conforme apontam os trabalhos de Rios (2010, 2011), Vitorino (2008), Vitorino e Piantola $(2009,2011)$ e Vitorino e Orelo (2012), sendo elas a técnica, estética e ética, as quais serão descritas e aprofundadas a seguir.

\subsubsection{Aspectos políticos da Competência em Informação}

A dimensão política da competência em informação está relacionada ao comportamento do indivíduo em sociedade a partir do uso da informação. O modo como se apropria e utiliza a informação no cotidiano, influencia as decisões e consequentemente o curso de vida. A sociedade da aprendizagem demanda das pessoas conhecimentos que permitem a análise crítica e cautelosa das informações disponíveis, pois diante do excesso de conteúdos é fundamental saber avaliar o que é relevante, confiável e útil. Rios (2010) aponta que é tarefa dos professores, por meio de sua atuação, contribuir para a formação da cidadania, e para tanto é preciso articular dialeticamente as dimensões da competência.

O exercício da cidadania seria o objetivo de se trabalhar a dimensão política da competência, visto constituir em condição fundamental para o desenvolvimento social. Segundo Vitorino e Piantola (2011): 
O recente desenvolvimento das sociedades democráticas, aliado ao crescimento acelerado da oferta de produtos informacionais, tem levado os governos de diversos países a empreender esforços no sentido de incentivar programas voltados à competência em informação de seus cidadãos, visando à sua participação nas decisões e nas transformações referentes à vida social, ou seja, ao exercício de sua cidadania (VITORINO; PIANTOLA, 2011, p.106).

\subsubsection{Aspectos éticos da Competência em Informação}

Para abordar sobre ética da informação é preciso definir o que é informar. Ou seja, o trabalho do professor, do bibliotecário, jornalista e demais profissionais que lidam com a informação como objeto de trabalho é atribuir valor à informação a fim de transmiti-la com algum propósito.

Le Coadic (2004, p.5) afirma que "o objetivo da informação permanece sendo a apreensão de sentidos ou seres em sua significação, ou seja, continua sendo o conhecimento". Sendo assim, o propósito da disseminação da informação é levar conhecimento a quem quer que seja, independente do formato (suporte) no qual a informação esteja registrada. Já a ética pode ser definida como o "encontro do conhecimento com a reflexão que pode contribuir decisivamente para a emancipação humana" (GASQUE, TESCAROLO, 2004, p.39). Os autores acreditam que a geração de conhecimento na sociedade da aprendizagem só pode acontecer por meio do pensamento reflexivo, que por sua vez deve ser pautado na ética para ser efetivo.

De acordo com Werthein (2000, p.77), alguns aspectos éticos da informação devem ser discutidos na sociedade contemporânea. O primeiro está relacionado aos direitos de propriedade intelectual, inclusive na internet em que o público e privado confundem-se cotidianamente. Tais princípios são denominados info-éticos; o segundo diz respeito às informações de domínio público disponibilizadas para a sociedade, essas informações devem ser de maior qualidade e públicas na internet de acordo com critérios de adequabilidade de formato e idioma para que a população possa efetivamente acessá-los. 
Um dos maiores problemas que enfrentamos hoje é o de plágio nos trabalhos acadêmicos. Muitos tendem a achar que o que está disponível na rede é de domínio público, e talvez por não ter nenhum conhecimento a respeito usam e copiam indiscriminadamente imagens, fotos, textos e ideias de outrem sem mencionar a fonte. Plágio ${ }^{4}$ é crime previsto em lei, e este é um dos aspectos fundamentais da competência em informação que deve ser desenvolvido pelos indivíduos.

\subsubsection{Aspectos estéticos da Competência em Informação}

Almeida (2012), em texto no qual analisa as relações entre educação e estética propostas por Nietzsche, afirma que na percepção do filósofo o educando é visto como ser ativo e não passivo, e que o modelo de educação deve formar indivíduos autônomos e reflexivos. Ainda nesse texto, o autor aponta que Nietzsche era contra a omissão ao educando dos processos de criação, ou seja, a liberdade para criar no contexto educacional é o ponto-chave das ideias.

A estética na educação seria, então, a possibilidade de proporcionar a liberdade criativa do indivíduo ao colocar as vontades como prioridade. "Uma verdadeira educação certamente precisa retomar o criar como processo que não pode ser subordinado. O criar deve constituir a peça fundamental da educação" (ALMEIDA, 2012, p.196). Uma educação que seja pautada no criar e na liberdade do estudante de buscar fontes de informação, relacioná-las a fim de produzir conhecimento novo, possibilitaria, dentre outras coisas, maior autonomia do indivíduo, mas para tanto necessitamos de educadores preparados para conduzir o processo.

Ao pensarmos nos aspectos reflexivos do uso da informação, na produção de novos conhecimentos a partir das experiências vividas, e na capacidade de definir o que é útil, temos então estabelecida a relação entre os conceitos de competência e estética.

\footnotetext{
${ }^{4}$ Lei número 9.610, disponível em: http://www.planalto.gov.br/ccivil_03/leis/l9610.htm
} 
Portanto, se o homem é um ser social, que vive em comunidade e todas as experiências vividas se dão no contato com o outro, entende-se que a Estética está relacionada, também, à sensibilidade social, ou seja, se reflete na cidadania, na solidariedade, na generosidade e no bem estar do indivíduo e do coletivo (ORELO; VITORINO, 2012, p.51).

A relação entre a competência em informação e a estética se daria então no momento em que o indivíduo dotado de sensibilidade, espírito crítico e capacidade de reflexão, consegue agir como cidadão e em coletividade. De acordo com Gasque e Tescarolo (2004, p.37) "quanto maior a capacidade de refletir, mais significativo e mais aprofundado será o pensar empregado na elaboração do conhecimento". Isto é, na concepção dos autores o pensamento reflexivo permite que a produção de novos conhecimentos, a partir das informações que recebemos, seja mais fundamentado e significativo.

\subsubsection{Aspectos técnicos da $\mathrm{Cl}$}

Os aspectos técnicos da competência em informação são os mais evidentes, e talvez por isso os mais pesquisados. Dizem respeito à capacidade do indivíduo demonstrar conhecimentos e habilidades práticas ao fazer algo. Nas pesquisas da área são utilizados alguns padrões e também instrumentos que visam aferir os níveis de competência técnica de forma objetiva, se o pesquisado sabe manusear uma fonte de informação, se conhece os critérios, as normas, as tecnologias e assim por diante.

Segundo Vitorino e Piantola (2011, p.102), "a ideia de técnica refere-se, portanto, a uma atividade eminentemente prática, de caráter objetivo, que se revela na própria ação cotidiana". Os aspectos técnicos envolvidos no uso da informação dizem respeito principalmente ao processo de busca por informação, no qual a pessoa precisa ser capaz de identificar as necessidades de informação, localizar a fonte, aplicar os critérios para avaliá-la e por fim utilizá-la para sanar sua dúvida.

A ênfase sobre a técnica explica-se pelo fato de ela constituir a dimensão mais evidente da competência em informação, na medida em que é o meio de ação do indivíduo no contexto da informação. Uma análise mais detalhada, contudo, revela que essas ações não devem existir por si mesmas, mas sim derivar de 
determinadas motivações e contextos particulares, gerando uma série de consequências éticas e sociopolíticas (VITORINO; PIANTOLA, 2011, p.102).

O trabalho desenvolvido pelas autoras, como mencionado inicialmente, esclarece e elucida diversas questões sobre a competência a partir da divisão em dimensões. Os quatro aspectos abordados são apresentados na figura a seguir.

Figura 2 - Resumo das características das dimensões da competência em informação

\begin{tabular}{|c|c|c|c|}
\hline Dimensão técnica & Dimensão estética & Dimensão ética & Dimensão política \\
\hline $\begin{array}{l}\text { Meio de ação no } \\
\text { contexto da informação. } \\
\text { Consiste nas habilidades } \\
\text { adquiridas para } \\
\text { encontrar, avaliar e usar } \\
\text { a informação de que } \\
\text { precisamos. } \\
\text { Ligada à ideia de que o } \\
\text { indivíduo competente } \\
\text { em informação é aquele } \\
\text { capaz de acessar com } \\
\text { sucesso e dominar as } \\
\text { novas tecnologias. }\end{array}$ & $\begin{array}{l}\text { Criatividade sensível. } \\
\text { Capacidade de } \\
\text { compreender, } \\
\text { relacionar, ordenar, } \\
\text { configurar e ressignificar } \\
\text { a informação. } \\
\text { Experiência interior, } \\
\text { individual e única do } \\
\text { sujeito ao lidar com os } \\
\text { conteúdos de } \\
\text { informação e sua } \\
\text { maneira de expressá-la e } \\
\text { agir sobre ela no âmbito } \\
\text { coletivo. }\end{array}$ & $\begin{array}{l}\text { Uso responsável da } \\
\text { informação. } \\
\text { Visa à realização do } \\
\text { bem comum. } \\
\text { Relaciona-se a questões } \\
\text { de apropriação e uso da } \\
\text { informação, tais como } \\
\text { propriedade intelectual, } \\
\text { direitos autorais, acesso } \\
\text { à informação e } \\
\text { preservação da memória } \\
\text { do mundo. }\end{array}$ & $\begin{array}{l}\text { Exercício da cidadania. } \\
\text { Participação dos } \\
\text { indivíduos nas decisões } \\
\text { e nas transformações } \\
\text { referentes à vida social. } \\
\text { Capacidade de ver além } \\
\text { da superfície do } \\
\text { discurso. } \\
\text { Considera que a } \\
\text { informação é produzida } \\
\text { a partir de (e em) um } \\
\text { contexto específico. }\end{array}$ \\
\hline
\end{tabular}

Fonte: Vitorino e Piantola (2011, p.109).

As autoras explicam que as quatro dimensões se complementam, e que "todas devem estar presentes em harmonia tanto na competência quanto na informação, pois juntas e em equilíbrio tendem a favorecer o desenvolvimento da competência em informação" (VITORINO; PIANTOLA, 2011, p.102). 


\section{CAPÍTULO 4}

PROGRAMAS DE LETRAMENTO INFORMACIONAL E A FORMAÇÃO DE PROFESSORES E BIBLIOTECÁRIOS

A educação para a competência é atividade fundamental para que possamos almejar uma sociedade com maior capacidade de transformar informação em conhecimento e, em consequência disso, atuar de forma mais cidadã. O professor e o bibliotecário são os pilares para a consolidação do movimento e, portanto, devem ser capacitados para que possam se tornar multiplicadores. Esse capítulo destina-se a discutir a relação entre competência em informação e educação, o aprendizado ao longo da vida e a formação de professores e bibliotecários.

\subsection{COMPETÊNCIA EM INFORMAÇÃO E EDUCAÇÃO}

É na escola que o indivíduo começa o processo de formação e é também nesse ambiente que ele tem a oportunidade, ou deveria ter, de questionar, aprender, interagir com os conteúdos transmitidos e produzir conhecimento a partir da interpretação e reflexão. Nesse espaço, portanto, que se deve trabalhar em prol do desenvolvimento de conhecimentos, procedimentos e atitudes para o uso da informação, uma vez que "a aquisição do capital intelectual do sujeito está diretamente ligada ao número de anos passados na escola e aos títulos adquiridos no decorrer deste período" (MOTA, 2006, p.123).

Como a informação e o conhecimento são fatores preponderantes na sociedade, a transmissão pelos professores precisa ser repensada, novas estratégias devem ser adotadas para possibilitar diversas formas de aprendizado. $O$ professor, mais do que nunca, deve questionar o papel e as metodologias de ensino-aprendizagem possibilitando uma educação transformadora. Segundo Dudziak (2003), a função do docente é de facilitador, aquele que promove a liberdade do estudante, o deixa criar mas realiza a mediação do processo. Para Cruz (2008, p.1025) "a capacidade reflexiva do aluno é elemento essencial para o discernimento do conhecimento, já que é ela que o torna capaz de interpretar, comparar, ponderar e integrar as informações". 
A educação contemporânea deve desenvolver no estudante um conjunto de conhecimentos que permita que ele tome decisões, confronte opiniões, busque diversas fontes de informação para construir o próprio entendimento a respeito de algo. Trata-se não apenas de uma educação para a autonomia, mas para a sua emancipação como indivíduo. Nesse sentido, "os conhecimentos necessários para buscar e usar informação de forma eficiente e eficaz são conteúdos que devem ser ensinados, aprendidos, aplicados e avaliados" (GASQUE; CUNHA, 2010, p.143). Sendo assim a educação para a informação está "no cerne de uma nova e desejada sociedade "incluída", que seja amparada na consideração "cuidadosa" de uma educação que envolva novas e ousadas abordagens relacionadas ao acesso à informação por meio das TICs" (SILVA et al., 2005, p.35).

A evolução da internet e das demais tecnologias de informação e comunicação impactaram diretamente na educação e no fazer do bibliotecário e do professor. No caso do bibliotecário, as tecnologias digitais, catálogos virtuais e uma infinidade de serviços disponíveis online ao invés de ameaçarem a atuação, como muitos previam, possibilitam que esse profissional se reinvente, pois por mais que a informação esteja ao alcance da maioria, há contingente gigantesco de pessoas que não sabe acessá-la e que possuem dificuldades em identificar o que é de qualidade, sendo assim a função do bibliotecário mais do que nunca é primordial. $O$ professor tem o papel de mediar o processo de aprendizado, e não apenas expor o conhecimento, ao auxiliar o estudante a produzir a própria compreensão a partir das informações que recebe. É um processo de colaboração mútua e construção conjunta do aprendizado, no qual "o professor pode estimular nos alunos o gosto pela leitura e pela biblioteca quando frequenta a biblioteca escolar e, em parceria com o bibliotecário busca promover atividades que envolvam as disciplinas contempladas no projeto pedagógico" (MOTA, 2006, p.125).

O desenvolvimento de programas de letramento informacional no cotidiano, não apenas dos professores e bibliotecários, mas da escola, é fundamental para que possa ser prática adotada. Para que a discussão se torne possível é preciso primeiramente que os professores se conscientizem da importância do tema, e para tanto o ideal seria 
ter a disciplina de LI nos cursos de formação. O desafio é imenso, pois é preciso trabalho de sensibilização e aproximação da Ciência da Informação com a Educação, que ainda ocorre de forma tímida. Dudziak (2003) acredita que a inclusão do tema na educação seria mudança de paradigma que exigiria questionamentos de vários fatores, entre eles o aprendizado, as políticas educacionais e a constituição de novos perfis profissionais, o que demandaria tempo.

Gasque (2010) aponta que o processo de letramento informacional, fundamental para o desenvolvimento da competência, não tem sido foco da educação brasileira, em especial no que se refere à educação básica. Isso acarreta vários problemas futuros, como estudantes que entram na graduação sem nenhuma experiência com atividades que envolvem pesquisa, por exemplo. Infelizmente esse é o retrato da educação superior hoje.

Para que uma mudança significativa se efetive há implicações em questões culturais e sociais que no Brasil não estão bem resolvidas. Existem poucas bibliotecas escolares e públicas, quando existem são precárias e não contam com Bibliotecário; os investimentos públicos na área são tímidos; não existe cultura do livro e da leitura no país, e nem reinvidicação popular por bibliotecas de qualidade, como demonstrado na pesquisa Retratos da Leitura no Brasil de 2011. Diante desse cenário evidenciam-se alguns dos motivos de não concretizarmos uma sociedade da aprendizagem.

Segundo Freire (1996, p.22) "é preciso que o professor ainda em sua formação reconheça que ensinar não é transferir conhecimento, mas criar as possibilidades para a sua produção ou a sua construção". Sendo assim, o professor consciente da atuação e do papel como mediador terá como foco a criatividade e a busca por conhecimentos que possibilitem atuação mais próxima ao educando, ou seja, atuará como pesquisador. Não há como dissociar a educação da pesquisa.

$\mathrm{Na}$ era da informação, o espaço de saber do docente foi dando lugar ao de mediador e problematizador do aprender: ele passou a ser visto como aquele que desafia os alunos, mostrando-lhes, entre as várias possibilidades de aprendizagem, caminhos que poderão ser percorridos (CRUZ, 2008, p.1027). 
O bibliotecário possui outro papel, apesar de não estar em sala de aula, deve fazer parte do planejamento pedagógico da escola, participando ativamente das atividades desenvolvidas, dando o suporte necessário à execução das tarefas (FARIAS, VITORINO, 2009). Enquanto o profissional não for visto como fundamental para a escola, dificilmente será valorizado. Dudziak (2011) aborda tal questão apontando que o bibliotecário deve se envolver pessoal e socialmente com a comunidade na qual atua a fim de que tanto os estudantes, quanto professores e demais funcionários entendam o trabalho do bibliotecário.

O bibliotecário deve ter postura pró-ativa e se capacitar para atuar na escola com o letramento informacional, uma vez que os conhecimentos são fundamentais para implantação desse processo. Nas diretrizes apontadas pela American Association of School Librarians - AASL denominadas Information Power: Guidelines for School Libraries Media Programs, citadas por Campello (2003, p.30), aparecem como atribuições do bibliotecário o papel de professor, aquele que participa do processo de ensino-aprendizagem, ensinando os estudantes a pensar criticamente, e também o de consultor didático, inserindo a biblioteca no projeto político pedagógico da escola, colaborando e participando ativamente das atividades curriculares. Tais iniciativas evidenciam que a importância dada à competência em informação torna as bibliotecas e os bibliotecários atores fundamentais no processo de desenvolvimento social.

Campello (2003) acredita que a inserção do tema na agenda de discussões e trabalhos da área de biblioteconomia, possibilitou ampliar a função pedagógica da biblioteca e do bibliotecário, promovendo mudança de paradigma. De acordo com Santos (2011), o bibliotecário deve assumir postura de liderança na atuação em conjunto com outros profissionais e sendo pró-ativo na busca da democratização do acesso à informação.

É fundamental, então, que o bibliotecário busque desenvolver as próprias competências para trabalhar a informação de forma menos técnica e mais contextualizada. Para que isso se torne possível, deve se capacitar constantemente e compreender melhor o papel de educador. Além disso, é preciso evidenciar o que uma 
biblioteca faz, quais serviços oferece, para quê serve e em que medida pode auxiliar a comunidade escolar e também aquela a que pertence. "O desenvolvimento de programas educacionais voltados para a information literacy se faz a partir de uma mudança de filosofia de educação, não mera inclusão de atividades que objetivem a habilitação em certas atividades ligadas à informação" (DUDZIAK, 2003, p.31).

Ao falarmos de educação que promova o uso eficiente e eficaz da informação, precisamos de políticas públicas e profissionais que façam coro a esses anseios. No Brasil não há, na prática, políticas de implantação de bibliotecas públicas e escolares, por mais que isso esteja no discurso. Não se seguem os parâmetros de qualidade sugeridos pelos profissionais da informação, e por tal motivo as bibliotecas, quando existem, são negligenciadas (GASQUE; COSTA, 2003).

A última pesquisa Retratos da Leitura no Brasil ${ }^{5}$ divulgada, em 2011, apresenta dados que merecem análise mais aprofundada e atenção por parte de professores, bibliotecários e claro, do governo. Vamos nos ater àqueles que dizem respeito ao foco desta pesquisa. O primeiro dado que chama a atenção é a quantidade média de livros que o brasileiro lê por ano: 4 livros, sendo 2 em partes e 2 por completo. Isso nos faz perceber o quanto é preciso ser feito ainda para a população valorizar a leitura.

Outros dados chamam a atenção na pesquisa e trazem importantes reflexões para a educação e também para a Ciência da Informação. Por exemplo, a pessoa que mais influenciou os pesquisados a ler foi o professor, seguido da mãe. Ou seja, o professor é o responsável direto pelo incentivo à leitura, as ações dele são determinantes para que o indivíduo perceba a leitura como atividade prazerosa e importante para o crescimento pessoal e profissional. O bibliotecário nem sequer é mencionado, o que pode ser considerado reflexo da ausência desse profissional no ambiente escolar. É realmente difícil reconhecer como importante alguém que não se conhece. A figura 3 a seguir apresenta o detalhamento dos dados.

\footnotetext{
${ }^{5}$ A pesquisa Retratos da Leitura no Brasil pode ser encontrada na íntegra no site do Instituto Pró-livro no endereço: http://prolivro.org.br/home/
} 
Figura 3 - Pessoas que influenciam os pesquisados a ler

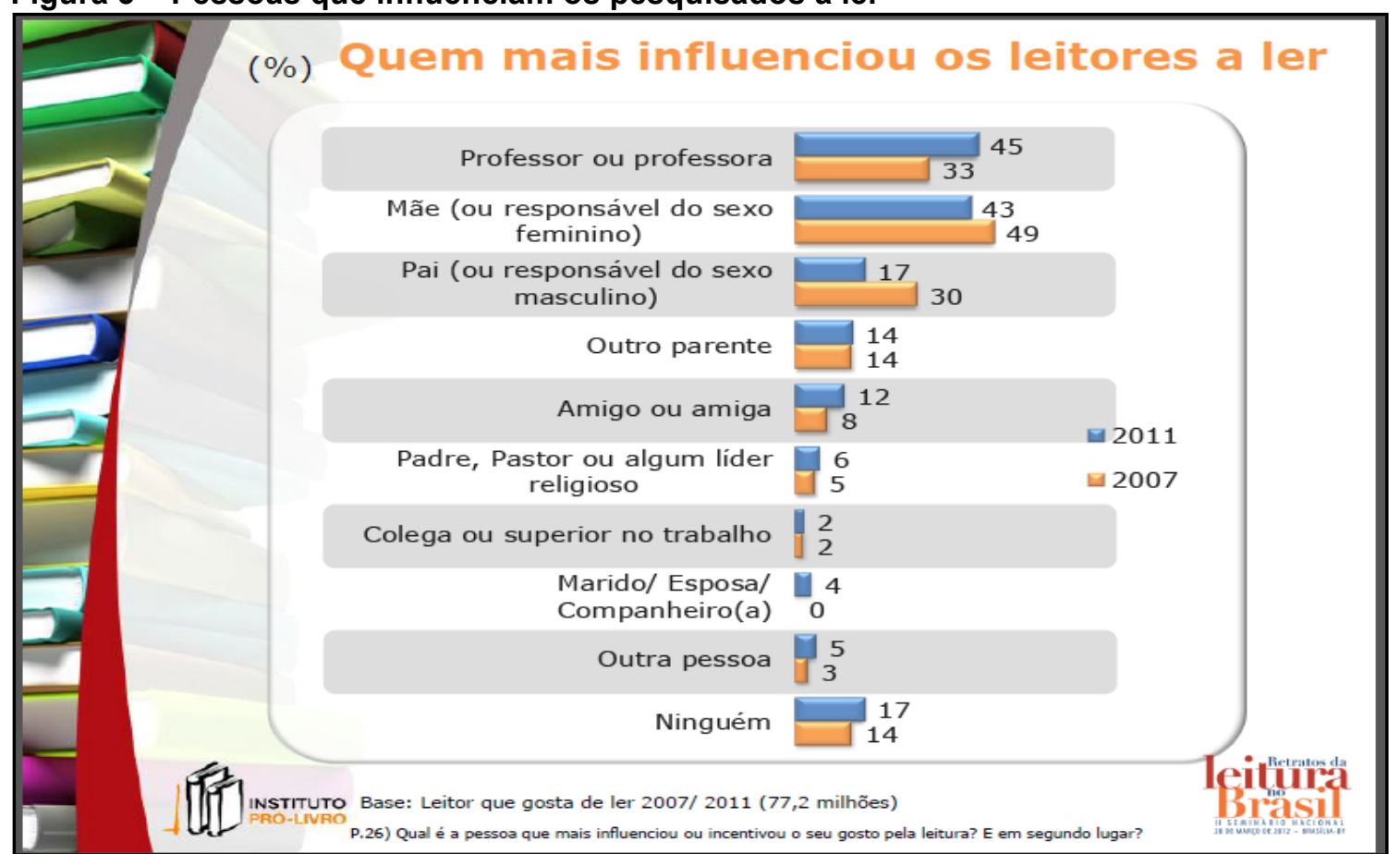

Fonte: Pesquisa retratos da leitura no Brasil (2011).

Outro ponto relevante refere-se ao questionamento sobre o que a biblioteca representa. Para a maioria dos pesquisados, constitui-se como local de estudo e pesquisa, ou seja, as pessoas possuem visão tradicional, que não contempla o que uma biblioteca moderna deveria representar para a sociedade, isto é, espaço integrado de atividades de leitura, estudos, manifestações culturais, ponto de referência para a comunidade, entre outras funções.

Os resultados da pesquisa indicam a necessidade de haver parceria entre bibliotecários e professores para que a leitura seja valorizada como atividade fundamental para a vida. Professores e bibliotecários precisam entender os papeis de cada um, trabalhar em conjunto, trazer a sala de aula para a biblioteca e vice-versa. A biblioteca escolar constitui-se como peça fundamental e integradora ente os fazeres dos dois profissionais, sendo o ambiente adequado para essa interação. O problema é que no Brasil o que costuma-se chamar de biblioteca, na maioria das escolas, é um espaço inadequado, com acervo desatualizado, sem parâmetros e políticas efetivas, o que na maioria das vezes faz com que não passem de meros apêndices do sistema 
educacional (GASQUE; TESCAROLO, 2010). A figura 4 apresenta os resultados do que a biblioteca representa para os pesquisados.

Figura 4 - 0 que a biblioteca representa

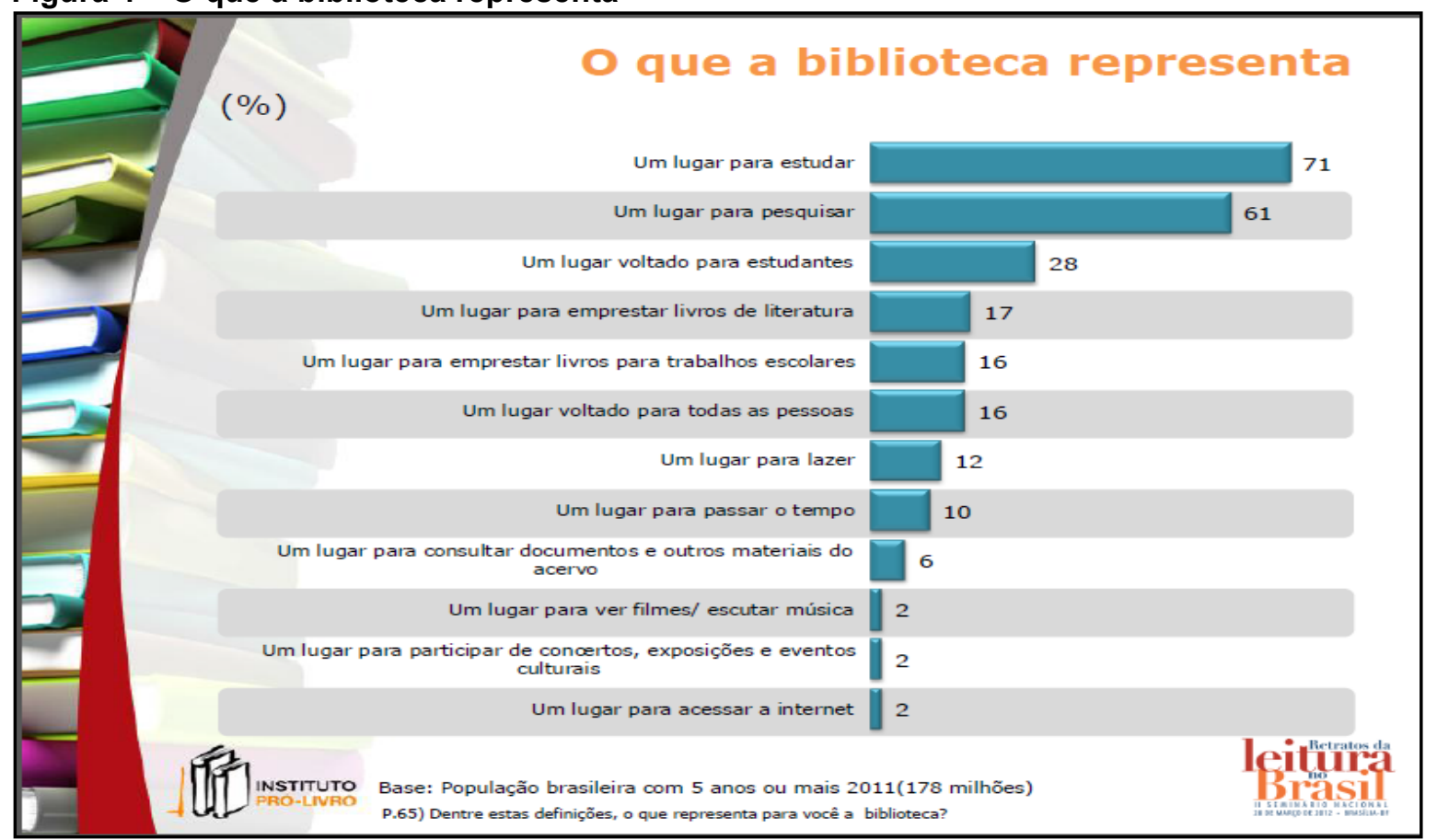

Fonte: Pesquisa retratos da leitura no Brasil (2011).

Diante do exposto, é perceptível o quanto a ausência de bibliotecas públicas e escolares de qualidade afeta os índices de leitura e a percepção do que a mesma representa. Uma educação voltada para a competência seria uma saída visto que:

[...] socializa o acesso à informação, ao conhecimento e ao aprendizado. Incentiva a participação ativa da comunidade (ou seja, seu comprometimento) na definição de objetivos educacionais. Busca o aprendizado enquanto processo de conteúdos significativos. Enfatiza a integração curricular e a educação baseada em recursos. Adota práticas pedagógicas voltadas para a construção de conhecimento, o aprendizado independente e o aprendizado ao longo da vida, a partir da elaboração de projetos de pesquisa e da resolução de problemas (DUDZIAK, 2003, p.32).

\subsection{APRENDIZADO AO LONGO DA VIDA}

Para tratar de aprendizado ao longo da vida (lifelong learning), é preciso definir o que é aprender. Só se aprende aquilo que faz sentido, duas pessoas podem receber a 
mesma informação e uma delas compreender e a outra não. Isso acontece porque a informação só se constitui como tal se o receptor a decodificar e interpretar. Se isso não ocorrer ela passará despercebida. Dito isso, aprender significa assimilar algo a partir do estoque inicial de conhecimentos e da bagagem sociocultural, é sempre um processo individual que depende de internalização (BELLUZZO; KOBAYASHI; FERES, 2004).

Parece ser consenso que o desenvolvimento de competências que possibilitam o uso consciente da informação é essencial para a atuação do indivíduo na sociedade, sendo assim é preciso que o mesmo "estabeleça uma nova relação com a informação e com o saber, uma relação de aprendizado ao longo da vida" (VITORINO; PIANTOLA, 2009, p.131). Uma relação na qual ele tenha autonomia para identificar as demandas por novos conhecimentos e possua ferramentas e instrumentos para adquiri-los, num processo contínuo de aprendizado.

Belluzzo (2005, p.45), baseando-se em Ausubel (1963), acredita que a aprendizagem significativa ocorre "quando um conceito implica em significados claros, precisos, diferenciados e transferíveis". Sendo assim, para que a aprendizagem ocorra é necessário relacioná-la com o conhecimento prévio do indivíduo.

Aprender ao longo da vida significa buscar conhecimentos para atuar no campo profissional ou pessoal, a fim de se manter atualizado e em conformidade com as exigências do mercado de trabalho e da vida em sociedade. Além disso, há o estudo pelo prazer de conhecer. O conhecimento possui uma característica que é a dinamicidade, então a partir das pesquisas e do desenvolvimento social novos conhecimentos são gerados, e isso demanda das pessoas capacitação constante.

Para Cruz (2008, p. 1037) "a aprendizagem tem como base o caráter inventivo. Desse modo, aprender é aprender a aprender, para continuar aprendendo e inventando a si mesmo e ao mundo". Uma sociedade que tem a educação fundamentada no aprendizado ao longo da vida baseia-se no aprender a aprender, como aponta Dudziak (2011): 
Quando se considera a existência de uma sociedade de aprendizagem, a melhor educação é aquela que prepara os aprendizes para o aprendizado continuado através do aprender a aprender. A dimensão social e coletiva de qualquer processo educacional/informacional de qualidade começa a se sobressair. Busca-se a inserção dos indivíduos na dinâmica da sociedade atual. Por isso se fala em sociedade de aprendizagem (DUDZIAK, 2011, p.175).

O aprendizado contínuo está diretamente relacionado ao letramento informacional. Para que seja possível o aprendizado constante, é fundamental que a educação esteja voltada para a autonomia do indivíduo, que o oriente a buscar pelo conhecimento para sanar as dúvidas e permita o crescimento pessoal e profissional. Nessa vertente, a educação a distância se transforma em instrumento fundamental para que as pessoas possam se capacitar, pois a tecnologia permite estudar sem sair de casa.

De acordo com Belluzzo (2004, p.24), "é preciso que seja desenvolvida uma nova dimensão do aprender, em que o desenvolvimento do raciocínio, da capacidade de criação e inovação possam ser priorizados. Ensinar a aprender muito mais do que ensinar a fazer". Ou seja, aprender vai muito além de dominar ou entender os conteúdos recebidos, implica em saber aplicá-los sempre que houver necessidade.

Se o aprender é o foco, o ensinar se torna ainda mais importante, pois estratégias precisam ser revistas e a formação do professor deve estar de acordo com o que é almejado socialmente. Segundo Orelo e Vitorino (2012, p.47), "o 'aprender a aprender', pode-se dizer, é a essência para o desenvolvimento humano e permite que o cidadão adquira habilidades cognitivas, comece a pensar criticamente, o que, por sua vez, é fundamental para o exercício da cidadania".

Fialho (2004), ao realizar pesquisa para identificar as implicações do uso das fontes de informação na formação do pesquisador juvenil, bem como verificar a atuação do professor e da biblioteca na realização da pesquisa escolar, chega a algumas conclusões importantes: 
- A prática da pesquisa escolar é condição essencial para o desenvolvimento da competência em informação;

- A articulação entre a proposta pedagógica da escola, a influência da família, do professor, da biblioteca e dos colegas contribui para o desenvolvimento da competência em informação.

Diante desses resultados, fica evidente a importância do professor, da biblioteca e do bibliotecário no ambiente escolar para que os programas de letramento possam ser desenvolvidos.

\subsection{A FORMAÇÃO DE PROFESSORES}

Muitos são os autores da área que discutem o papel do professor no desenvolvimento da competência em informação dos estudantes, entre eles Fialho (2004) destaca que:

O papel do professor em uma escola inserida na sociedade da informação é o de facilitador em um processo de ensino-aprendizagem que se baseia em uma variedade de fontes de informação. O professor passa a exercer uma influência ativa e propulsionadora na busca da informação e na produção de novos conhecimentos, o que poderá contribuir para aflorar nos alunos um espírito investigativo (FIALHO, 2004, p.84).

Ou seja, o professor comprometido com o desenvolvimento crítico dos estudantes precisa rever as metodologias de ensino constantemente para se adequar às demandas atuais da sociedade. Possui a função de instigar a pesquisa, a curiosidade, pois para que os indivíduos possam pertencer a sociedade de forma legítima, precisam estar preparados e capacitados para usar a informação efetivamente. "Uma visão clara, abrangente e profunda do papel que desempenha e deve desempenhar na sociedade permite ao educador uma atuação mais competente" (RIOS, 2011, p.20). 
Cruz (2008) destaca a mudança no papel do professor na era da informação, deixando pra trás a figura de centralizador do conhecimento, transformando-se em mediador, aquele que desafia o estudante a buscar novos caminhos, novas possibilidades de aprendizado. Ainda segundo o autor, "este papel de mediador e instigador do conhecimento, que o educador passa a assumir na era da informação, não reduz nem minimiza sua responsabilidade com a formação do sujeito, muito pelo contrário, deve contribuir para uma formação humana e ético-social" (CRUZ, 2008, p.1029).

A educação deve estar pautada na efetividade do comportamento informacional por parte dos indivíduos, que envolve a identificação das necessidades de informação, a busca, aquisição, seleção e uso da informação no cotidiano e para a tomada de decisões. O foco deve estar no conhecimento e não na informação, na capacidade criativa e de mobilização do saber.

A sugestão é de que se adote abordagem multidisciplinar para desenvolver a competência em informação, com o envolvimento de outros profissionais além dos bibliotecários, principalmente os professores e pesquisadores, uma vez que estão diretamente envolvidos na luta por uma sociedade mais justa e solidária (GASQUE, 2008). Além disso, hoje, está claro que o processo de formação é contínuo, permanente e que nunca se esgota ou completa, enquadrando-se na perspectiva do lifelong learning, até porque as mudanças no mundo do trabalho não param de ocorrer e para se adaptar é preciso buscar capacitação (VITORINO, 2008).

Parece ser crucial na formação básica do professor a existência de conteúdos curriculares que o capacite a lidar eficaz e eficientemente com a informação. Nesse sentido, deveria haver um conjunto de disciplinas que permitissem a reflexão sobre a busca e o uso da informação na sociedade da aprendizagem. E que, para além dessa formação, a consciência sobre a importância da formação continuada como modo de se capacitar para lidar com as mudanças a que estamos sujeitos. Para Gasque e Tescarolo (2010), é importante destacar o papel da reflexão como elemento 
fundamental para o crescimento pessoal e coletivo, sendo indispensável na formação básica e continuada dos professores.

Para Almeida (2012, p.196), "uma verdadeira educação certamente precisa retomar o criar como processo que não pode ser subordinado. $O$ criar deve constituir a peça fundamental da educação". A criatividade deve ser estimulada pelos professores, pois é uma forma de possibilitar que os estudantes desenvolvam suas aptidões individuais e não se tornem meros reprodutores de conteúdos.

De acordo com Pozo (2004, p.35), "não cabe mais à educação proporcionar aos alunos conhecimentos como se fossem verdades acabadas; ao contrário, ela deve ajudá-los a construir seu próprio ponto de vista, sua verdade particular a partir de tantas verdades parciais". A construção do conhecimento por parte do estudante deve ocorrer em conjunto com o professor.

Na tentativa de minimizar os problemas informacionais que a sociedade enfrenta, Le Coadic (2004) propõe a educação para a informação, na qual sejam ensinadas habilidades para que a pessoa seja capaz de aprender a se informar, como também informar aos outros. Para tanto, o autor acredita na criação de uma disciplina que deveria ser ensinada desde o ensino básico para que os conhecimentos acerca do manejo da informação possam ser internalizados e aprimorados ao longo da vida.

\begin{abstract}
A introdução no ensino da disciplina 'informação', com um quadro de professores especializados, seria a garantia de ingresso dos alunos na sociedade da informação. Permitiria lutar contra esse considerável analfabetismo informacional e contra um crescente iletrismo informacional, e, portanto, suprimir a distância que hoje separa os inforricos dos infopobres (LE COADIC, 2004, p.113).
\end{abstract}

Uma iniciativa importante nesse sentido é o curso de formação de professores elaborado pela Organização das Nações Unidas para a Educação, a Ciência e a Cultura - UNESCO ${ }^{6}$. Publicado, em 2013, o documento intitulado Alfabetização Midiática e Informacional: currículo para formação de professores aponta diretrizes para

\footnotetext{
${ }^{6}$ Documento disponível no endereço: http://unesdoc.unesco.org/images/0022/002204/220418por.pdf
} 
que estes adquiram competências para lidar com as mídias e a informação na educação. O documento evidencia a importância das mídias e da informação para os indivíduos exerçam a cidadania com a utilização de princípios da competência em informação.

\begin{abstract}
As mídias e outros provedores de informação, como bibliotecas, arquivos e internet, são amplamente reconhecidos como ferramentas essenciais para auxiliar os cidadãos a tomarem decisões bem informadas. São também os meios pelos quais as sociedades aprendem sobre elas mesmas, mantêm discursos públicos e constroem um sentido de comunidade. Os canais de mídia e demais TICs podem ter um grande impacto sobre a educação continuada, e, por isso, os cidadãos precisam de um conhecimento básico sobre as funções das mídias e de outros provedores de informação e sobre como acessá-los. O propósito da alfabetização midiática e informacional é transmitir esse conhecimento aos usuários (UNESCO, 2013, p.16).
\end{abstract}

A importância desse documento diz respeito principalmente ao entendimento claro de que para que os estudantes possam se tornar alfabetizados em mídias e informação é preciso capacitar primeiro os docentes, para que os mesmos sirvam de multiplicadores. Por isso, apresenta programa para a formação de professores com esse fim, que pode ser visualizado na figura 5 por meio da matriz curricular.

Por meio da concepção do referido curso, percebemos que, para uma pessoa se tornar competente em informação, ela precisará não apenas desenvolver habilidades na obtenção da informação de que necessita, mas principalmente se apoderar delas, exercendo o papel de cidadã ao atuar na sociedade de forma consciente. Deverá ser capaz de avaliar os conteúdos, conhecer diferentes mídias e fontes de informação, e utilizá-las. 
Figura 5 - Dimensões Curriculares propostas pela UNESCO para a formação de professores

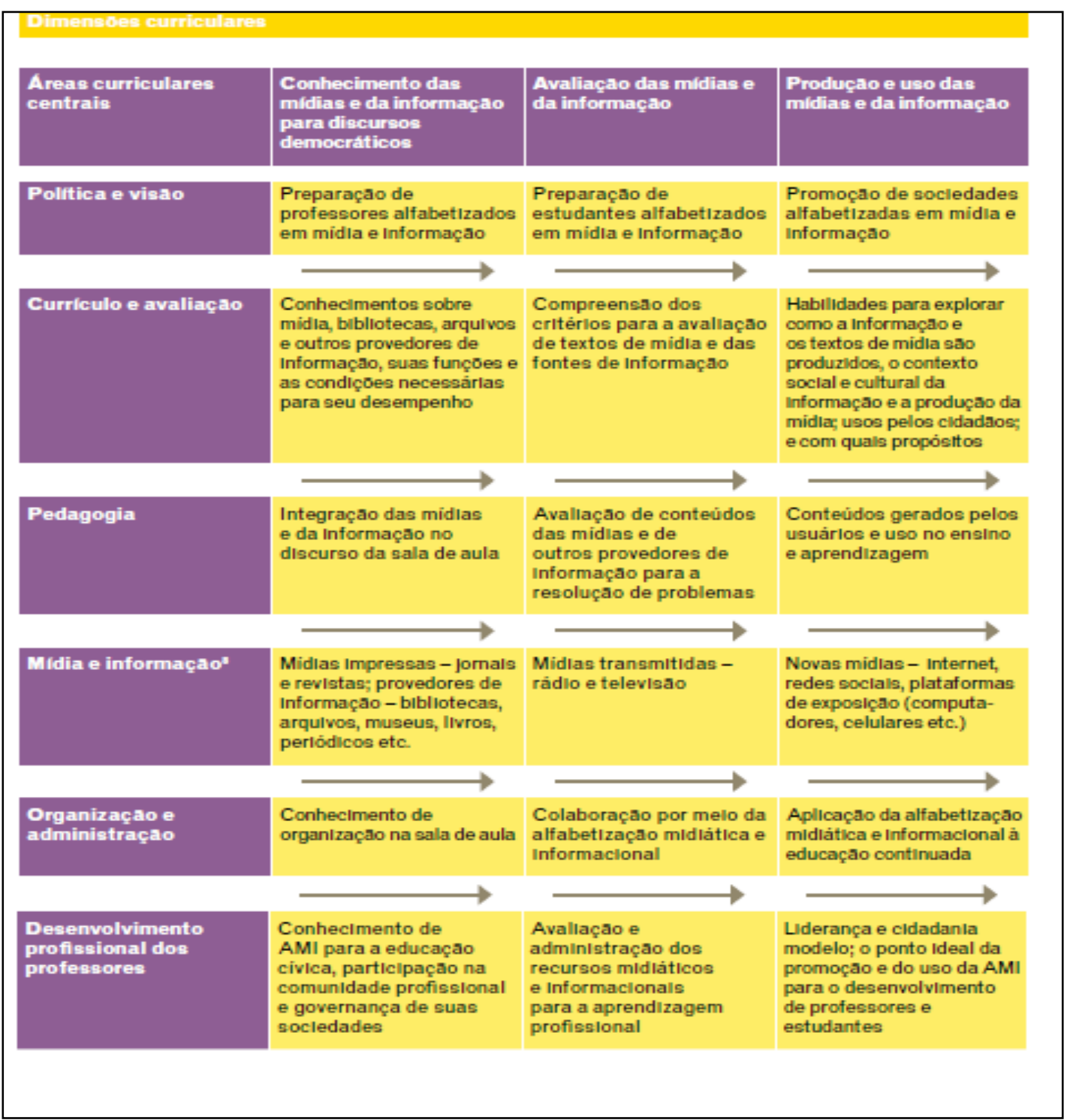

Fonte: http://unesdoc.unesco.org/images/0022/002204/220418por.pdf

Em pesquisa realizada sobre formação de professores, Belluzo; Kobayashi e Feres (2004) concluíram que o uso de princípios da competência em informação aliados à construção de mapas conceituais pode influenciar significativamente a aprendizagem, o que pode ser estratégia levada em consideração.

Tanto a formação básica/inicial do professor como a formação continuada precisam contribuir para o desenvolvimento da information literacy, competência considerada importante para o desempenho ideal desse processo (BELLUZZO, 2004). 
Para desenvolver essa capacidade é mister que "o professor precisa se inserir em um processo de formação permanente que implica também a busca de informação para construção de novos conhecimentos" (GASQUE; COSTA, 2003, p.56).

A educação a distância tem permitido aos professores capacitar-se e suprir lacunas que possam ter ocorrido na formação básica. A UAB por meio da CAPES oferta diversos cursos gratuitos em várias universidades do país com o objetivo de auxiliar na capacitação docente. É uma forma da tecnologia se aliar à educação não apenas como instrumento didático-pedagógico em sala de aula, mas também de capacitação.

Belluzzo e Kerbauy (2004, p.134) delimitam algumas medidas que as escolas precisam estabelecer, por meio dos currículos, para formar professores competentes em informação, quais sejam:

- A instituição deve ter compromisso com a obtenção de resultados excelentes para que os professores e estudantes aprendam a pensar criticamente, saibam solucionar problemas e desenvolvam as habilidades de informação.

- Os professores e bibliotecários do sistema escolar devem atuar de forma interdisciplinar, a fim de juntos promoverem programas de formação voltados ao desenvolvimento da competência em informação.

- Os professores não podem preparar devidamente os estudantes para serem competentes em informação, sem que compreendam como acessar e usar a informação para a produção de conhecimento.

- Há necessidade de se estabelecer padrões e indicadores de performance para que tanto os professores como estudantes conheçam as habilidades e como identificá-las ao longo do processo de ensino-aprendizagem.

Sem educação não há reflexão, não há mudança. Para que o professor exerça a função na sociedade da aprendizagem, primeiramente, precisa ser capacitado para compreender as características dessa sociedade e agir de forma crítica, por isso precisa ter competência em informação. O papel docente não é apenas de transmitir 
informações sem propiciar a reflexão e a análise crítica, mas a importância dele reside em possibilitar aos estudantes encontrar as respostas de forma autônoma e participativa. Os papéis que estudante e professor terão que desempenhar são desafiadores. Para Cruz (2008, p.1028) "professor e aluno terão de aprender a lidar com as novas tecnologias e também com os modelos tradicionais para adquirir as informações necessárias para sua formação profissional e pessoal." O desafio não é simples, e ambos terão que se adaptar.

Aquele que ensina deve ter conhecimento para transmitir os conteúdos, isso implica que diante das tecnologias e de tantas informações disponíveis, o professor que não domina e não possui competência em informação não será capaz de promover o aprendizado de tal competência por parte dos estudantes. Se não houver disciplina que o auxilie na formação e no entendimento dos processos envolvidos na busca e no uso da informação, dificilmente ele terá arcabouço teórico e prático para ensinar. Assim, a formação do professorado precisa ser repensada no sentido de formar professores pesquisadores.

Transformar a informação em conhecimento que possa ser aplicado no dia a dia dos estudantes é o desafio dos educadores. É preciso criatividade, dinamicidade e capacitação adequada para que isso se concretize, uma vez que como aponta Moran (2000), por meio das tecnologias os dados e as informações estão à disposição de todos, portanto a aquisição da informação dependerá cada vez menos do professor, que terá o papel principal de ajudar o estudante a interpretar, relacionar e contextualizar os dados e informações que recebe. Rios (2010, p.52) afirma que "por intermédio do gesto de ensinar, o professor, na relação com os alunos, proporciona a eles, num exercício de mediação, o encontro com a realidade, considerando o saber que já possuem e procurando articulá-lo a novos saberes e práticas", o que demonstra a importância da postura de articulador, mediador que o professor deve adotar. 


\subsection{A FORMAÇÃO DO BIBLIOTECÁRIO}

Para se discutir sobre a formação profissional do bibliotecário é fundamental pensar no perfil demandado pela sociedade e pelo mercado de trabalho. Mueller (1989, p.64) identifica questões que devem ser feitas ao se discutir essa formação:

- Identificar as funções profissionais próprias do bibliotecário.

- Identificar as funções desempenhadas pelos bibliotecários no Brasil.

- Levantar novos campos de atuação para o bibliotecário.

- Descrever o perfil profissional ideal do bibliotecário.

O perfil do bibliotecário tem se alterado ao longo dos anos. Com as mudanças sociais e tecnológicas foi preciso se adaptar e passar a oferecer serviços e produtos adequados às novas demandas dos usuários, que estão se tornando cada vez mais autônomos nos processos de busca e uso de informações.

De acordo com Silva e Arruda (2000), o bibliotecário moderno apresenta algumas qualificações indispensáveis na formação. É importante que ele tenha conhecimento sobre as tecnologias da informação; domine mais de um idioma; seja criativo e inovador; tenha facilidade de se adaptar às mudanças e inúmeras outras qualificações, que surgem de acordo com as novas demandas de informação e de tecnologias.

Outro fator chave nesse processo de mudanças é a Internet, que possibilita a recuperação de informações de maneira ágil, mas ao mesmo tempo propicia grande excesso de informação, que sem olhar crítico fica difícil identificar o que é realmente relevante. Nessa perspectiva, o bibliotecário tem a função de educar, auxiliar o usuário a lidar com a informação.

É fundamental ter em mente que novas tecnologias sempre existirão, pois o processo de inovação é contínuo. Por isso, caberá a cada profissional, por meio das 
motivações pessoais, buscar as competências necessárias para lidar com o mundo tecnológico, afinal, disso dependerá a permanência no mercado de trabalho.

O bibliotecário passou por diversas mudanças na formação ao longo do tempo, como revela Guimarães (1997):

- erudito, ligado à cultura e à arte (1911-1930);

- ênfase na formação técnica, foco no tratamento e organização de documentos (1930-1960);

- educador, agente cultural (década de 80);

- multifacetado, foco no usuário e na informação e não no suporte (início da década de 90 até hoje).

A atuação desse profissional que antes se restringia aos limites da Biblioteca, hoje com o auxílio das TICs não há mais limites. O bibliotecário está onde existe informação para ser analisada, processada, armazenada e disseminada e mais, o trabalho com a educação de usuários é fundamental para a sociedade. Segundo Valentim (2000, p.3), "a informação, como objeto de trabalho e estudo do Bibliotecário, tem sido afetada pelas tecnologias de informação, modificando seu formato, seu suporte, seu processamento e disseminação, influindo na forma de mediação entre o Bibliotecário e o usuário/ cliente".

Trata-se do Bibliotecário atualmente como MIP (Modern Information Professional). De acordo com Guimarães (1997), é aquele que consegue gerenciar unidades e sistemas de informação; sabe tratar a informação e conhece as fontes e promove ações sociais, ajuda a resgatar a cidadania, auxilia na inclusão social. Em tempos em que há supervalorização da tecnologia, jamais se pode perder de vista esse papel.

Essa mudança de paradigma requer que o profissional tenha aptidões para lidar com informação em diversos ambientes, seja organizacional, educacional, ou virtual. 
Isso implica formação além daquela obtida na graduação, como cursos de capacitação, especialização, mestrado e doutorado.

Não foi somente o perfil do Bibliotecário que passou por mudanças significativas, o do usuário também, que está mais autônomo nas buscas por informação, apesar de ainda não identificar o que é realmente relevante. Neste sentido, o bibliotecário desempenha atividades semelhantes àquelas desenvolvidas pelos professores por se preocupar, de acordo com Mueller (1989, p.64) "não em fornecer informação propriamente dita, mas orientar pessoas na aquisição de conhecimentos e prepará-las para que possam, sozinhas, buscar informações sempre que precisarem." A função dele é de educar, mostrar o caminho para a resolução de problemas a partir do uso consciente da informação.

Uma possibilidade de minimizar alguns problemas acerca da formação do bibliotecário é a de que os cursos de graduação tenham em vista o desenvolvimento das aptidões de cada um, onde a criatividade seja estimulada, e que as disciplinas técnicas não tenham mais ênfase do que as demais. Por sua vez, os profissionais graduados precisam se capacitar continuamente, participando de eventos como congressos e seminários, com o intuito de conhecer as pesquisas desenvolvidas na área. Também é de fundamental importância que haja a preocupação com a pesquisa uma vez que em alguns temas a literatura da área encontra-se defasada.

Em relação à formação do bibliotecário para atuar no ambiente educacional, principalmente na biblioteca escolar, percebe-se que os cursos de graduação deverão atualizar os currículos a fim de que possam conter disciplinas que possibilitem um olhar pedagógico ao profissional. Sobre as práticas desenvolvidas pelos bibliotecários na escola, Campello (2009) argumenta que os bibliotecários empreenderam maior esforço nas atividades de promoção da leitura e menos nas de instrução à pesquisa escolar, o que indica que as práticas para a consolidação da competência em informação no Brasil ainda estão aquém das ações desenvolvidas nos países desenvolvidos. 
É fundamental que o bibliotecário se conscientize do papel de educador e se capacite para exercer ações dessa natureza, de modo a auxiliar no desenvolvimento da competência em informação. A formação acadêmica não é o suficiente para ser considerado competente, é preciso investir em formação continuada (FARIAS; VITORINO, 2009).

$\mathrm{Na}$ dissertação de mestrado, Santos (2011) trabalhou com os estudantes do último período do curso de biblioteconomia da Universidade Federal de Goiás, com o objetivo de identificar a competência em informação deles baseando-se nos padrões propostos pela ACRL. Os resultados da pesquisa demonstraram, em linhas gerais, que os estudantes saem da graduação mais competentes em alguns aspectos do que em outros, possuindo, por exemplo, melhor desempenho em relação à avaliação eficiente da informação e maior dificuldade na classificação das fontes. O estudo evidenciou também que é possível que a graduação compense a defasagem oriunda da escola pública, mas, para tanto, é preciso envolvimento do corpo docente.

Após a publicação da $\operatorname{Lei}^{7} \mathrm{n}^{\circ} 12.244$, em 24 de Maio, de 2010, que determina que em um prazo de dez anos, a contar da data de publicação, as escolas passem a ter biblioteca com bibliotecário, a maior preocupação passa a ser com a formação desse profissional. Ele deve ter competências para atuar no desenvolvimento de programas de letramento informacional na escola, visto que este é o seu papel fundamental no ambiente educacional.

Mata e Casarin (2012) explicam que não necessariamente por se formar em biblioteconomia o graduando sairá da universidade competente em informação, pois há pesquisas que apontam os déficits na formação do profissional. As autoras evidenciam ainda que há preocupação em nível mundial com os currículos dos cursos de biblioteconomia, atentando para a inserção dos conteúdos relativos à competência em informação.

\footnotetext{
${ }^{7}$ Lei disponível na íntegra no endereço: http://www.planalto.gov.br/ccivil_03/_ato2007-2010/2010/lei/l12244.htm
} 
A oferta de cursos de educação continuada para bibliotecários a fim de capacitálos em relação à competência em informação tem crescido, tanto por parte de associações de classes quanto pelas escolas de biblioteconomia e ciência da informação (MATA; CASARIN, 2012). Isso pode ser indicador de que os bibliotecários estão demandando por novos conhecimentos, e em contrapartida o mercado está oferecendo capacitação para suprir essa demanda.

Em pesquisa realizada pelas supracitadas autoras a respeito dos currículos dos cursos de biblioteconomia do país, que disponibilizam as disciplinas em sites institucionais, 8 oferecem alguma disciplina relacionada à competência. Ao analisarem as ementas, as autoras consideram que alguns parâmetros deveriam ser adotados ao se definir o conteúdo dessas disciplinas, pois cada curso aborda o tema de uma maneira, por vezes, generalista e com ausência de pontos fundamentais. Em relação às disciplinas que abordam conteúdos voltados para a formação pedagógica, o resultado mostra que 12 cursos apresentam alguma disciplina voltada à didática ou relacionadas aos conteúdos educacionais, somando 34 disciplinas. Elas concluem que "há um número restrito de disciplinas voltadas para a formação pedagógica, considerando-se que este conteúdo é fundamental quando se trata da competência em informação, em que o bibliotecário assume a postura de um educador/ instrutor em sessões de instrução em programas desta natureza" (MATA; CASARIN, 2012, não paginado).

Por sua vez, Farias e Vitorino (2009) evidenciam que para o bibliotecário escolar ser considerado competente não basta apenas dominar os conceitos da área, é preciso refletir criticamente sobre os conteúdos que promovem o LI. Assim, evidencia-se que o bibliotecário é profissional fundamental para que a competência e o letramento informacional possam ser desenvolvidos na escola, mas para tanto alguns fatores precisam de atenção, quais sejam, a formação básica e continuada, o interesse do profissional pela área educacional e a postura de educador. 


\section{CAPÍTULO 5}

\section{A EDUCAÇÃO A DISTÂNCIA COMO ESTRATÉGIA PARA A FORMAÇÃO CONTINUADA}

A educação a distância (EAD) tem se desenvolvido muito nos últimos anos, e um dos principais motivos refere-se ao uso das TICs, que possibilitaram a criação de plataformas didáticas online permitindo manter uma relação mais próxima e dinâmica com o estudante, e também auxiliando diretamente na produção de materiais didáticos audiovisuais mais interativos e interessantes. A busca pelo conhecimento, atualização, inserção no mercado de trabalho e uma necessidade cada vez maior de capacitação podem ser motivos para o crescimento da modalidade. Este capítulo tem a finalidade de apresentar a estrutura e evolução da EAD e a sua relação com a educação continuada.

\subsection{EDUCAÇÃO A DISTÂNCIA - HISTÓRICO E CARACTERIZAÇÃO}

A EAD pode ser caracterizada como uma modalidade de ensino alternativa que permite que pessoas residentes em áreas isoladas ou com acesso limitado à educação, possam estudar. Em seus primórdios era realizada via correio, transmitindo as informações e instruções para os alunos e recebendo destes as respostas das atividades desenvolvidas (ALMEIDA, 2003).

As bases da EAD no Brasil estão em cursos por correspondência como os ofertados pelo Instituto Universal Brasileiro na década de 60, e em cursos ditos como educação popular, por não serem formais representados principalmente pelas edições do Telecurso "produzidas pela rede globo em parceria com órgãos públicos e paraoficiais: Telecurso de $2^{\circ}$ grau, 1979, Fundação Padre Anchieta/TV Cultura de São Paulo; Telecurso de $1^{\circ}$ grau, 1984, Funteve/TV Educativa do Rio; Telecurso 2000, 1995, Sesi/SP" (BELLONI, 2002, p.129).

Com a evolução das tecnologias e, consequentemente, a utilização na EAD, foi possível que a modalidade se expandisse e tivesse maior alcance e também maior 
agilidade no contato com os estudantes. Hoje o modelo utilizado pressupõe a disponibilização de um ambiente virtual de aprendizagem (AVA), tutores para realizarem a interação entre $\circ$ ambiente e $\circ$ aluno, professores conteudistas responsáveis por desenvolver os materiais didáticos e instrucionais, pessoal técnico e de apoio e materiais didáticos para estudo, sejam no formato de livro, apostilas, CDROM ou outros objetos de aprendizagem. De acordo com Almeida (2003), o problema desta abordagem consiste no fato de que o professor, na maioria das vezes, não se envolve com o estudante, pois a interação fica a cargo do tutor, e se este não conhecer corretamente o conteúdo, não tiver sido preparado para tanto, pode tornar a relação com o aluno superficial e causar o desinteresse por parte deste.

Segundo o documento que aponta as diretrizes elaboradas pelo MEC para a $E A D$ no Brasil, no que diz respeito especificamente às tecnologias, há um entendimento de que o uso das mesmas deve estar apoiado "em uma filosofia de aprendizagem que proporcione aos estudantes a oportunidade de interagir, de desenvolver projetos compartilhados, de reconhecer e respeitar diferentes culturas e de construir o conhecimento" (MEC, 2007, p.9), ou seja, não é a mera existência e uso das TICs que farão a diferença, mas os propósitos com os quais são utilizadas.

Evidencia-se que diante de todo o aparato tecnológico disponível e em franco desenvolvimento, e da urgência por uma educação que transcenda o modelo tradicional (leia-se presencial, mediado por um professor) o campo educacional acaba se transformando numa enorme possibilidade de exploração capitalista. Grandes grupos econômicos estão interessados em investir, ainda mais em países em desenvolvimento, como o nosso (MORAN, 2000; BELLONI, 2002).

O e-learnig, modalidade de educação a distância que ocorre em plataformas online, passa a crescer e a se difundir. Não apenas em cursos de graduação ou pós, mas em cursos de curta duração para aqueles que desejam atualização e capacitação para atender às demandas do mercado. 
A relação entre tecnologia e educação possibilitou que a EAD se expandisse e passasse a investir na qualidade dos cursos oferecidos. Há plataformas cada vez mais interativas e dinâmicas, conteúdos desenvolvidos exclusivamente para o ambiente digital, sem contar na possibilidade de interação sem limites de tempo e espaço que ocorre no ambiente tradicional. É claro que não apenas de tecnologias sustenta-se a $E A D$, é preciso muito planejamento e equipes capacitadas nas várias fases de desenvolvimento do curso para que seja satisfatório. A ideia de que as TICs seriam a tábua de salvação para a educação não se concretizou, pois está cada vez mais evidente que são apenas instrumentos agregadores de valor ao ensino, mas não um fim em si mesmas.

A EAD hoje não ocorre apenas em cursos totalmente ou parcialmente à distância, mas é possível nos cursos de graduação presenciais algumas disciplinas ou mesmo conteúdos específicos de determinadas disciplinas, serem ofertados a distância, como uma forma de complementar a aula tradicional ou até mesmo numa tentativa de promover uma maior interação com os alunos. Pode ser uma solução, ainda que não total, nem a melhor, para possibilitar que a população tenha acesso ao ensino em diferentes níveis, visto que o acesso à internet tem chegado a cada vez mais pessoas.

No contexto da sociedade da aprendizagem é possível observar que há um elemento determinante para que os indivíduos pertençam efetivamente a essa sociedade: a educação. Qualquer país que almeje o desenvolvimento deve ter políticas que possibilitem o acesso da população à educação de qualidade, pois é o conhecimento que leva as pessoas à cidadania, como percebemos nas palavras de Rocha (2000):

É, pois, através do conhecimento do mundo, adquirido, formal e informalmente, a partir de suas experiências e do convívio em sociedade, pelas trocas linguísticas e reconhecimento de símbolos, em um processo sistemático de formação intelectual e moral do indivíduo, que se processa a construção de sua dimensão enquanto cidadão (ROCHA, 2000, p.40). 
Um equívoco percebido em EAD é a tentativa de reproduzir no ambiente digital o modelo tradicional de sala de aula, sem levar em consideração que o aprendizado e o tempo utilizados são completamente diferentes. Para que esse problema seja minimizado é preciso trabalhar em equipe, contando com o auxílio de profissionais de design gráfico, programação, desenhistas instrucionais, para desenvolver materiais específicos para tais ambientes (ALMEIDA, 2003).

O ambiente de aprendizagem a distância também pode funcionar como apoio ao ensino presencial. Pode-se introduzir formas de pesquisa e comunicação não presenciais para renovar a forma de dar aula, de investigar e modificar as relações aluno-professor e aluno-aluno dentro e fora de sala de aula.

Tanto em universidades que se dedicam a trabalhar com ensino a distância como presencial, é fundamental a preocupação com a busca de soluções que viabilizem a construção de uma estrutura básica que apoie sob todos os aspectos a geração, manutenção e disponibilização da informação, principalmente no formato digital (GONZALES; POHLMANN FILHO; BORGES, 2001, p. 102).

Segundo Almeida (2003, p.333) a EAD em meio digital geralmente está estruturada de acordo com o foco dado ao ensino, podendo este estar no aluno, no professor, no material instrucional desenvolvido ou na interação entre os participantes, como apontado a seguir:

- O material instrucional disponibilizado, cuja abordagem está centrada na informação fornecida por um tutorial ou livro eletrônico hipermediático. Essa abordagem se assemelha à autoinstrução e distribuição de materiais, chegando a dispensar a figura do professor.

- O professor, considerado o centro do processo educacional, o que indica abordagem centrada na instrução fornecida pelo professor, que recebe distintas denominações de acordo com a proposta do curso.

- O estudante, que aprende por si mesmo, em contato com os objetos disponibilizados no ambiente, realizando as atividades propostas a seu tempo e de seu espaço. 
- As relações que podem se estabelecer entre todos os participantes evidenciando um processo educacional colaborativo no qual todos se comunicam com todos e podem produzir conhecimento, como ocorre nas comunidades virtuais colaborativas.

O foco pode mudar de acordo com a atividade desenvolvida ou pode estar em todos os itens ao mesmo tempo, tudo depende dos propósitos do curso. A EAD da forma como existe hoje, não pode ser vista apenas como solução para prover educação àqueles que não possuem acesso devido à condições geográficas, mas sim como uma possibilidade de oferecer educação de qualidade e autoinstrucional para quem tiver interesse.

Hoje há plataformas de ensino interativas que colocam à disposição cursos das mais diversas áreas, e não apenas cursos de longa duração. O uso das TICS permite que existam cursos totalmente autoinstrucionais, o que contribui para tornar o processo mais autônomo, até porque "a palavra autonomia parece ser a palavra de ordem das propostas de educação a distância, pois o principal objetivo é o de facilitar o desenvolvimento da chamada aprendizagem autônoma" (ZUIN, 2006, p.946).

\subsection{A UNIVERSIDADE ABERTA DO BRASIL - UAB}

A Universidade Aberta do Brasil $^{8}$, também conhecida pela sigla UAB, é um sistema que congrega universidades públicas com o propósito de oferecer cursos de nível superior àqueles que por algum motivo (dentre eles o principal é a localização geográfica) tenham dificuldades de acesso à formação universitária. Segundo informações institucionais, apesar da população em geral ser atendida pelos cursos disponíveis, os professores que atuam na educação básica tem prioridade de formação, seguidos dos dirigentes, gestores e trabalhadores em educação básica dos estados, municípios e do Distrito Federal.

\footnotetext{
${ }^{8}$ Informações institucionais disponíveis em: http://uab.capes.gov.br/index.php/sobre-a-uab/o-que-e
} 
A criação vem ao encontro de uma política governamental de investimentos em educação e capacitação, principalmente de professores, por ser um país com baixo índice de estudantes universitários formados, entendendo que para que as nações se desenvolvam mais do que nunca, precisam formar pessoas, já que esta é uma exigência do capitalismo (ZUIN, 2006).

A UAB foi criada a partir do decreto 5.000 de 8 de Junho de $2006^{9}$ o qual determina os seus objetivos, quais sejam:

I. oferecer, prioritariamente, cursos de licenciatura e de formação inicial e continuada de professores da educação básica;

II. oferecer cursos superiores para capacitação de dirigentes, gestores e trabalhadores em educação básica dos Estados, do Distrito Federal e dos Municípios;

III. oferecer cursos superiores nas diferentes áreas do conhecimento;

IV. ampliar o acesso à educação superior pública;

V. reduzir as desigualdades de oferta de ensino superior entre as diferentes regiões do País;

VI. estabelecer amplo sistema nacional de educação superior a distância; e

VII. fomentar o desenvolvimento institucional para a modalidade de educação a distância, bem como a pesquisa em metodologias inovadoras de ensino superior apoiadas em tecnologias de informação e comunicação.

Constitui-se como uma rede que gerencia todos os cursos à distância ofertados pelas universidades públicas, desde a aprovação dos editais para criação de cursos novos, até o fomento dos mesmos. Geralmente em cada universidade parceira há um centro responsável pela EAD, o qual deve gerenciar os polos, o pagamento de bolsas, a seleção de tutores e toda a parte burocrática/administrativa demandada pela

\footnotetext{
${ }^{9}$ Decreto disponível na íntegra no endereço: http://www.planalto.gov.br/ccivil_03/_Ato20042006/2006/Decreto/D5800.htm
} 
educação a distância. Hoje o sistema é gerido pela CAPES. Na figura 6 é possível observar como se dá o funcionamento.

Figura 6 - Funcionamento do sistema UAB

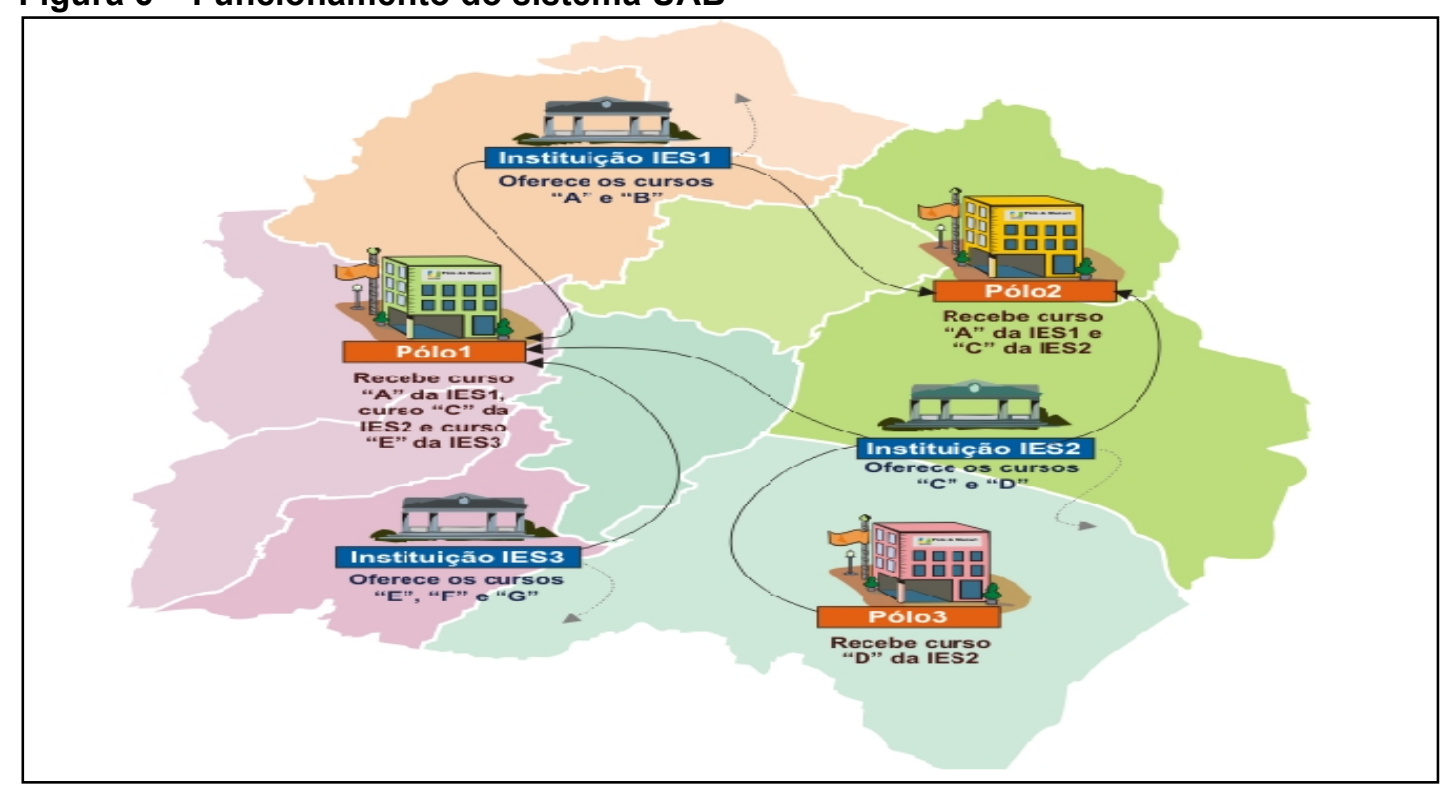

Fonte: http://uab.capes.gov.br/index.php/sobre-a-uab/teste

É uma parceria que envolve as três esferas governamentais, municipal, estadual e federal, onde cada uma entra com algum tipo de recurso. Os municípios interessados em participar do programa estabelecem o polo de apoio presencial, com a infraestrutura necessária para a oferta do curso a partir de financiamento próprio ou em parceria com entidades e com o Estado. $O$ polo ${ }^{10}$ deve oferecer laboratório de informática, biblioteca, sala multiuso para realização de aulas, provas e web conferências e contar com uma equipe de apoio que deve ser formada por um coordenador, secretário técnicoadministrativo, pessoal de limpeza e segurança, bibliotecário ou auxiliar de biblioteca e técnico em informática.

\footnotetext{
${ }^{10}$ Informações extraídas da página da UAB disponíveis em: http://uab.capes.gov.br/index.php/polos841937/modelo-de-polo
} 


\subsection{EAD COMO ESTRATÉGIA PARA A FORMAÇÃO CONTINUADA EM LETRAMENTO INFORMACIONAL}

A formação continuada pode ocorrer de diversas formas, por meio de cursos de curta duração, palestras, pós-graduação latu e stricto sensu, enfim, há uma diversidade de possibilidades para quem busca se capacitar, atualizar ou mesmo ampliar os conhecimentos. A educação a distância é uma dessas ferramentas, e devido ao alcance que pode ter, visto que permite às pessoas estudar sem sair de casa, torna-se fundamental em uma sociedade que demanda por capacitação. Além de que permite que certas regiões que não possuem universidades públicas sejam beneficiadas através de polos concebidos com a função de servir de apoio às atividades da EAD.

Na concepção da UAB, por exemplo, fica claro que um dos propósitos principais da oferta de cursos à distância é para a capacitação de professores, na tentativa de suprir o déficit que há em sua formação. Sendo assim a EAD é um instrumento de educação continuada e aprendizado ao longo da vida que corrobora com a perspectiva do letramento informacional.

Em pesquisa realizada sobre cursos de educação continuada de bibliotecários na área de competência e letramento informacional percebe-se que a EAD constitui-se como principal meio utilizado no Brasil. É o caso do curso intitulado Competência em Informação ${ }^{11}$, ofertado pela Federação Brasileira de Associações de Bibliotecários, Cientistas da Informação e Instituições - FEBAB, em 2014. O curso foi realizado na modalidade à distância com carga horária de $50 \mathrm{hs}$, ministrado pela professora Dudziak, com vagas apenas para bibliotecários.

A Universidade Federal do Ceará promoveu no mês de Maio de 2015 um curso $^{12}$ de 32hs com o título: Desenvolvimento da Competência em Informação no Contexto

\footnotetext{
${ }^{11}$ Informações sobre o curso disponíveis no endereço: $\underline{\text { http://febab.org.br/?page_id=838 }}$

${ }^{12}$ Informações sobre o curso disponíveis em: http://www.ufc.br/noticias/noticias-de-2015/6638-inscricoesabertas-para-curso-de-competencia-em-informacao-para-servidores
} 
Universitário, destinado a servidores técnico-administrativos e docentes da instituição. O objetivo foi aprimorar conhecimentos e habilidades relacionadas ao acesso e uso da informação.

A empresa MMH Informação ${ }^{13}$ ofertou de Maio a Junho de 2015 o curso: a competência em informação para gestores do conhecimento nas organizações, coordenado pela professora Belluzzo. Teve como público-alvo profissionais de diversas áreas que atuam com informação e conhecimento como fatores estratégicos nas organizações.

A iniciativa considerada mais abrangente em relação ao letramento informacional é a do CELI, como apontado no primeiro capítulo, e por tal motivo o referido curso foi escolhido como objeto de estudo da tese.

Pesquisa realizada em julho de 2015 no Google acadêmico com as palavraschave "Letramento informacional/competência em informação e educação a distância" recuperou dois artigos publicados no Brasil, que integram os dois temas. Vitorino (2009) discorre sobre a aprendizagem contínua, a "presencialidade", a flexibilidade, a "distancialidade", a alfabetização digital e a interação como elementos possíveis na construção do conhecimento na modalidade a distância. Afirma que a competência em informação na EAD torna-se fundamental para a construção do conhecimento. Por sua vez, Gomes, Fialho e Silva (2013) analisaram a competência em informação dos agentes envolvidos no ensino a distancia da Universidade Federal de Goiás. São considerados agentes, os coordenadores, tutores e auxiliares de bibliotecas. Os dados mostraram que os participantes da pesquisa se declararam competentes na maioria dos padrões estabelecidos pela ACLR, exceto naqueles que dizem respeito ao acesso eficiente da informação (padrão 2) e à compreensão das dimensões econômica, legal e social que permeiam o uso da informação (padrão 5).

\footnotetext{
${ }^{13}$ Informações sobre o curso disponíveis em: http://www.mmhinformacao.com.br/pg/cursos.php?detalhe=sim\&id_curso=13
} 
No portal da CAPES, em julho de 2015, foi realizado levantamento bibliográfico com os descritores "distance education" and "information literacy" com a recuperação de 606 resultados. Desses, 168 foram artigos de periódicos revisados por pares. Em seguida, esse resultado foi refinado por data de publicação, considerando somente os artigos entre 2010 e 2015, em um total de 63. Entretanto, a análise item a item mostrou grande número de artigos repetidos, artigos sem integração dos dois temas e, por fim, itens fora do formato estipulado, por exemplo, resenhas, recursos textuais, dentre outros. Por fim, foram analisados 14 artigos. Em cada um deles, foram identificados 0 tema de pesquisa, o sujeito e as conclusões principais, como se observa no quadro 1. O objetivo é apresentar panorama das pesquisas publicadas sobre o assunto nos últimos cinco anos.

Quadro 1: Pesquisas publicadas entre 2010/2015 com os temas LI e EAD

\begin{tabular}{|c|c|c|c|}
\hline Tema de pesquisa & Objeto & Conclusão & Autores \\
\hline $\begin{array}{l}\text { Aprendizagem situada } \\
\text { (AS) em cursos de LI a } \\
\text { distância }\end{array}$ & 85 universitários & $\begin{array}{l}\text { Modelo de ensino fundamentado em AS melhora a transferência de } \\
\text { conhecimento. }\end{array}$ & Catalano \\
\hline $\begin{array}{l}\text { Uso dos recursos de } \\
\text { bibliotecas digitais e } \\
\text { autoeficácia em curso } \\
\text { de LI a distância. }\end{array}$ & 3.517 estudantes de EAD & $\begin{array}{l}\text { Estudantes com elevada auto eficácia demonstram mais } \\
\text { conhecimentos em selecionar recursos. }\end{array}$ & Tang; Tseng \\
\hline $\begin{array}{l}\text { Aprendizagem baseada } \\
\text { em problemas (APB) } \\
\text { em módulo de LI a } \\
\text { distância }\end{array}$ & $\begin{array}{l}\text { Análise de artigos de } \\
\text { pesquisa e artigos de } \\
\text { opinião dos estudantes. }\end{array}$ & $\begin{array}{l}\text { A APB foi eficaz para alguns estudantes, mas não para todos. } \\
\text { Metade dos estudantes se engajaram nas questões mais } \\
\text { aprofundadamente e apresentaram estratégias de avaliação mais } \\
\text { sofisticadas e pensamento metacognitivo. }\end{array}$ & Diekema, Holliday, Leary \\
\hline $\begin{array}{l}\text { Modelo contextual de Li } \\
\text { a distância surgido a } \\
\text { partir da disciplina de } \\
\text { sistema de informação } \\
\text { geográfica (GIS) }\end{array}$ & Relato & $\begin{array}{l}\text { A junção dos dois programas possibilitaram um conjunto de } \\
\text { competências transferíveis, como facilitador para a aprendizagem } \\
\text { independente. }\end{array}$ & Nazari \\
\hline $\begin{array}{l}\text { Visão holística em } \\
\text { cursos de LI a distância }\end{array}$ & $\begin{array}{l}\text { Revisão analítica da } \\
\text { literatura }\end{array}$ & $\begin{array}{l}\text { Baseando-se em estudo contextual de Nazari de LI em um } \\
\text { programa de ensino à distância on-line de 2011, propõe uma forma } \\
\text { holística de ver e praticar LI em ambientes eletrônicos, alinhada } \\
\text { com origens do LI. Essa abordagem permite que o e-estudante de } \\
\text { LI conceitue e personalize o seu estilo de aprendizagem. }\end{array}$ & Nazari, Webber \\
\hline $\begin{array}{l}\text { Screencasting (captura } \\
\text { de ações em uma tela } \\
\text { de computador com o } \\
\text { objetivo de mostrar aos } \\
\text { outros como realizar } \\
\text { tarefas em um site ou } \\
\text { em um determinado } \\
\text { ambiente de software) } \\
\text { como ferramenta de } \\
\text { ensino de LI }\end{array}$ & 103 professores & $\begin{array}{l}\text { A maioria das reações dos participantes com os screencasts } \\
\text { informais do bibliotecário foram positivos ou muito positivos, mas } \\
\text { muitos participantes ainda preferem receber as resposta para as } \\
\text { perguntas por e-mail. }\end{array}$ & Bailey \\
\hline $\begin{array}{l}\text { Projeto piloto com uso } \\
\text { do Skype }\end{array}$ & $\begin{array}{l}\text { Revisão de literatura e } \\
\text { descrição do projeto pelos } \\
\text { autores }\end{array}$ & $\begin{array}{l}\text { Skype tem limitações como ferramenta para formação; no entanto, } \\
\text { mostrou ser efetivo no "primeiro passo" para a formação a distância. }\end{array}$ & Heather, Nicole \\
\hline $\begin{array}{lr}\text { Relações } & \text { entre } \\
\text { avaliação crítica de }\end{array}$ & Estudantes de graduação & $\begin{array}{l}\text { Os resultados sugerem relação significativa e positiva entre esses } \\
\text { letramentos. Estes achados sugerem uma variedade de tipos de }\end{array}$ & Van De Vord \\
\hline
\end{tabular}




\begin{tabular}{|c|c|c|c|}
\hline $\begin{array}{l}\text { informações on-line, } \\
\text { como uma medida de } \\
\text { letramento } \\
\text { informacional } \\
\text { componentes } \\
\text { letramento mediático. }\end{array}$ & & $\begin{array}{l}\text { estratégias que instrutores e designers instrucionais podem } \\
\text { empregar para o desenvolvimento de competências de letramento } \\
\text { informacional. }\end{array}$ & \\
\hline $\begin{array}{l}\text { Estratégias de } \\
\text { aprendizagem e fatores } \\
\text { motivacionais }\end{array}$ & 119 e-formandos & $\begin{array}{l}\text { A metacognição, a gestão do esforço, elaboração e estratégias de } \\
\text { pensamento crítico, bem como a crença no controle se relacionam à } \\
\text { diferentes dimensões de autoeficácia do LI }\end{array}$ & Kilik - Cakmac \\
\hline $\begin{array}{l}\text { Webconferência para } \\
\text { cursos de LI a distância }\end{array}$ & $\begin{array}{l}\text { Estudantes de pós- } \\
\text { graduação on-line }\end{array}$ & $\begin{array}{l}\text { Devido às limitações da tecnologia, houve redução na quantidade } \\
\text { de informação que fornecida simultaneamente aos estudantes. A } \\
\text { comunicação clara com os usuários (estudantes e professores) é a } \\
\text { chave para qualquer programa bem-sucedido de formação, } \\
\text { independentemente de ser presencial ou a distância. }\end{array}$ & Barnhart, Stanfield \\
\hline $\begin{array}{l}\text { Tutorial com uso de } \\
\text { screencast para ensino } \\
\text { de LI a distância }\end{array}$ & $\begin{array}{l}\text { Consultas } \text { com os } \\
\text { estudantes e } \\
\text { das estratégias de busçãa } \\
\text { finais. }\end{array}$ & $\begin{array}{l}\text { Embora o tutorial tenha sido bem aceito pelos estudantes, houve } \\
\text { necessidade de reforçar o conteúdo de ensino. }\end{array}$ & Boden, Murphy \\
\hline $\begin{array}{l}\text { Fundamentos de e- } \\
\text { learning para cursos de } \\
\text { LI a distância }\end{array}$ & Revisão de literatura & $\begin{array}{l}\text { As bibliotecas são o coração das instituições e, portanto, estão } \\
\text { destinadas a desempenhar papel vital nas atividades de } \\
\text { aprendizagem, bem como apoiar todos os tipos de aprendizagem, } \\
\text { que inclui e-learning. Há necessidade de formação para os } \\
\text { bibliotecários adotarem as tecnologias de e-learning e colaborarem } \\
\text { com faculdades e departamentos como tutores dos estudantes. }\end{array}$ & Eke \\
\hline $\begin{array}{l}\text { Bibliotecários atuantes } \\
\text { em EAD: estudo de } \\
\text { caso dos anúncios de } \\
\text { empregos }\end{array}$ & Anúncios de empregos & $\begin{array}{l}\text { Competências tecnológicas, conhecimento em ciência da } \\
\text { informação e comunicação são fundamentais para os bibliotecários } \\
\text { trabalharem em EAD. }\end{array}$ & Tang \\
\hline $\begin{array}{l}\text { Avaliação do curso de } \\
\text { LI a distância para } \\
\text { estudantes de medicina }\end{array}$ & $\begin{array}{l}\text { Estudantes de medicina } \\
\text { que se inscreveram no } \\
\text { curso entre outono de } \\
2008 \text { e outono de } 2010\end{array}$ & $\begin{array}{l}\text { Pontos positivos do curso: tempo e flexibilidade do espaço, estudo } \\
\text { no próprio ritmo e tutoriais interativos on-line. A maioria dos alunos } \\
\text { estavam satisfeitos com os tópicos ensinados como metodologia de } \\
\text { busca na base de dados Web of Science, Scopus e databases } \\
\text { médicos, uso do End Note Web e estilo de citação ISO } 690 \text {. A } \\
\text { maioria das tarefas, como busca nas bases de dados on-line ou } \\
\text { encontrar o fator de impacto de uma revista foram avaliadas como } \\
\text { benéficas. }\end{array}$ & Kratochvil \\
\hline
\end{tabular}

Fonte: Elaboração própria a partir dos dados encontrados no portal da CAPES (2015).

Esses temas foram classificados em quatro categorias, quais sejam, fundamentos de ensino-aprendizagem; ferramentas de EAD; competências do bibliotecário, avaliação e planejamento, como se apresenta no quadro 2.

Quadro 2: categorias dos temas de pesquisas publicadas entre 2010/2015 com os temas LI e EAD

\begin{tabular}{|l|l|}
\hline Categorias & Tema de pesquisa \\
\hline $\begin{array}{l}\text { Fundamentos de ensino- } \\
\text { aprendizagem }\end{array}$ & $\begin{array}{l}\text { Aprendizagem situada (AS) em cursos de LI a distância } \\
\text { Aprendizagem baseada em problemas (APB) em módulo de LI a distância. } \\
\text { Estratégias de aprendizagem e fatores motivacionais. } \\
\text { Fundamentos de e-learning para cursos de LI a distância. } \\
\text { Modelo contextual de Li a distância surgido a partir da disciplina de sistema de informação geográfica (GIS) }\end{array}$ \\
\hline Ferramentas de EAD & $\begin{array}{l}\text { Uso dos recursos de bibliotecas digitais e auto eficácia em curso de LI a distância. } \\
\text { Screencasting como ferramenta de ensino de LI. } \\
\text { Projeto piloto com uso do Skype. } \\
\text { Webconferência para cursos de LI a distância. } \\
\text { Tutorial com uso de screencast para ensino de LI a distância. }\end{array}$ \\
\hline $\begin{array}{l}\text { Competências do } \\
\text { bibliotecário }\end{array}$ & \begin{tabular}{l} 
Bibliotecários atuantes em EAD: estudo de caso dos anúncios de empregos \\
\hline Avaliação e planejamento
\end{tabular} \\
$\begin{array}{l}\text { Visão holística em cursos de LI a distância. } \\
\text { Relações entre avaliação crítica de informações on-line, como uma medida de letramento informacional e componentes } \\
\text { letramento mediático. } \\
\text { Avaliação do curso de LI a distância para estudantes de medicina. }\end{array}$ \\
\hline
\end{tabular}

Fonte: Elaboração própria (2015). 
A análise dos artigos dos últimos cinco anos publicados no portal da CAPES mostra, grosso modo, poucas pesquisas publicadas sobre cursos de letramento informacional por EAD, bem como a ausência de artigos que tratam de cursos de EAD para formação dos bibliotecários em LI. Isso parece um paradoxo, em especial, pelo esforço na conscientização da importância do letramento informacional na sociedade contemporânea, bem como a importância dos bibliotecários em assumir essa missão. Sobre isso Vitorino $(2008$, p.6) afirma que "é imprescindível nos dias atuais tratar da educação contínua ou permanente, ou ainda, da formação para toda a vida (lifelong learning) - de Profissionais da Informação, seja de forma presencial, seja na modalidade da Educação a Distância (EAD)". Observa-se também a necessidade de discutir a questão das competências necessárias aos bibliotecários para mediar cursos de $\mathrm{LI}$ em EAD. Os fundamentos de ensino-aprendizagem e as ferramentas de EAD foram as categorias mais exploradas, isso demonstra a importância dessas questões para que a implementação e consolidação de programas de LI, pois como Gasque (2010) afirma o LI precisa ser compreendido como processo de aprendizagem para o desenvolvimento das competência em informação. 


\section{CAPÍTULO 6 \\ REFERENCIAL TEÓRICO}

Este capítulo tem como propósito apresentar dentre os conceitos discutidos na revisão da literatura aqueles fundamentais para o arcabouço teórico da pesquisa. De acordo com Gasque (2008, p.108) o referencial teórico pode se compreendido como "marco por meio do qual o problema da pesquisa é interpretado", a partir da percepção do pesquisador. Os conceitos que fazem parte do referencial teórico da pesquisa são: Sociedade da aprendizagem, Letramento e competência em informação, Formação continuada de professores e bibliotecários, e Educação a distância.

\subsection{CONCEITOS ADOTADOS COMO REFERENCIAIS PARA A PESQUISA}

Nessa pesquisa, parte-se do princípio que a formação continuada é fundamental para o desenvolvimento da competência em informação de professores e bibliotecários, principalmente para apoiar a atuação na escola. Os três atores considerados nesse contexto são: a biblioteca, como ambiente de pesquisa e suporte ao ensino; o bibliotecário, agente promotor de diversos meios para que os estudantes compreendam o universo informacional e interfiram nele a partir de conhecimentos teóricos e práticos aprendidos (letramento informacional); e o professor, principal elo entre o conhecimento e o estudante. Gasque (2013), aponta que um dos temas emergentes da área a serem explorados é exatamente a formação de professores e bibliotecários, isso indica que há lacuna nessa área.

O modelo conceitual adotado na tese foi elaborado a partir da junção de princípios teóricos para a discussão sobre a formação continuada de professores e bibliotecários, sendo eles: a sociedade da aprendizagem; a competência em informação nas dimensões técnica, estética, ética e política; a educação para a competência em informação, incluindo a formação de professores e bibliotecários e, por último, a educação a distância como possibilidade de formação continuada desses profissionais. Cada um dos conceitos será abordado a seguir. 


\subsubsection{Sociedade da Aprendizagem}

A sociedade da aprendizagem possui características diretamente relacionadas ao desenvolvimento da competência em informação, tais como o uso das tecnologias de informação e comunicação, conhecidas como TICs; mercado mais globalizado no qual as pessoas podem estabelecer contatos de qualquer lugar do mundo mediante 0 rompimento das barreiras geográficas propiciado pelas tecnologias; a informação como o ativo principal, em que os investimentos nos processos para torná-la acessível e utilizável são cada vez maiores e a ideia do aprendizado contínuo, que alerta para a necessidade de atualização para responder às mudanças sociais. $O$ conceito de Sociedade da Aprendizagem adotado na pesquisa é apresentado por Pozo (2004):

\footnotetext{
Uma sociedade na qual aprender constitui não apenas uma exigência social crescente - que conduz ao seguinte paradoxo: cada vez se aprende mais e cada vez se fracassa mais na tentativa de aprender -, como também uma via indispensável para o desenvolvimento pessoal, cultural e mesmo econômico dos cidadãos (POZO, 2004, p.34).
}

O Brasil está muito distante de se concretizar como Sociedade da Aprendizagem, pois os investimentos em educação tanto em infraestrutura, quanto na valorização dos professores, é muito baixo. Além disso, há poucas bibliotecas de qualidade e profissionais preparados para lidar com o excesso de informação. Portanto, a cidadania, autonomia e visão crítica na sociedade da aprendizagem vinculam-se ao desenvolvimento do letramento informacional, que favorece os conhecimentos e competências necessários para buscar e usar a informação.

\subsubsection{Letramento Informacional e Competência em informação}

A competência no contexto atual representa a possibilidade de construção de uma sociedade mais democrática, ética e justa a partir da apropriação reflexiva da informação por parte dos indivíduos, sendo capazes de transformá-la em conhecimento. Competência refere-se à capacidade de colocar em prática os conhecimentos prévios a respeito de algo. Por usa vez, a competência em informação 
seria, então, a capacidade de selecionar, usar e produzir novas informações a partir do conhecimento adquirido, tanto técnico de uso das fontes, quanto intelectual, de produção de sentido.

Nessa pesquisa, compreende-se a competência em informação como produto do letramento informacional. Os termos não são considerados sinônimos. De acordo com Gasque (2010, p.88) o letramento informacional é um processo e a competência as habilidades desenvolvidas ao longo de tal processo, uma espécie de resultado prático. Um indivíduo que possui competência em informação é capaz de:

- Posicionar-se criticamente diante das situações.

- Identificar fontes de informação confiáveis e relevantes para solucionar os problemas.

- Identificar as necessidades informacionais da comunidade da qual faz parte.

- Interpretar a informação para gerar novos conhecimentos.

- Manipular corretamente os meios de comunicação.

Vitorino e Piantola (2009) explicam que:

O indivíduo competente informacional reuniria, assim, tanto as competências inicialmente previstas pelos bibliotecários quanto uma perspectiva crítica em relação à informação e ao conhecimento e ao seu próprio tempo, na medida em que permitiria uma percepção mais abrangente de como nossas vidas são moldadas pela informação que recebemos cotidianamente (VITORINO; PIANTOLA, 2009, p.136).

Sendo assim, o letramento informacional é uma condição para que a competência seja desenvolvida, e tanto professores como bibliotecários necessitam dos conteúdos trabalhados no LI para que possam se tornar competentes. A formação continuada é um dos caminhos possíveis para obter tais conhecimentos.

\subsubsection{Formação continuada de professores e bibliotecários}

O letramento informacional deve ocorrer ao longo da vida, mas com início desde a educação básica. Docentes e bibliotecários são responsáveis por desenvolver o LI na 
escola. Nesse sentido, esses profissionais precisam investir continuamente na formação inicial e continuada.

Em relação à formação profissional, compreende-se formação inicial como aquela obtida na graduação, e a formação continuada como uma possibilidade de atualização e também uma exigência a acompanhar a vida dos indivíduos em todas as áreas do conhecimento (PINTO, BARREIRO E SILVEIRA, 2010). Em relação à formação continuada dos docentes, os autores supracitados apontam que:

No caso da profissão docente, considerando as inúmeras mudanças nos sistemas social, cultural, político e econômico, essa imposição apresenta-se tanto como condição para acompanhar a evolução do conhecimento, como para redirecionar as ações docentes em busca do atendimento das novas demandas educacionais, as quais não vêm sendo alcançadas através do paradigma tradicional de ensino. Assim, a Formação Continuada dos professores em exercício tem sido citada como um possível suporte para auxiliar esses profissionais na ressignificação do seu fazer (PINTO; BARREIRO; SILVEIRA, 2010, p.3).

\subsubsection{Educação a distância para a formação continuada}

A Educação a distância refere-se a:

Uma estratégia pedagógica capaz de superar uma série de obstáculos que se interpõe entre sujeitos que não se encontrem em situação de presença física. Sua importância avulta cada vez mais em um mundo dependente de informações rápidas e em tempo real (MADEIRA, 2006, p.54).

As formas de ensinar e aprender mudaram, os limites da comunicação também, mas em contrapartida isso não significou evolução ou avanços significativos. Ao contrário, o volume de informação aumenta incontrolavelmente e demanda saberes mais específicos para sermos capazes de processá-las e integrá-las à vida. Moran (2000, p.138) aponta que "uma das dificuldades atuais é conciliar a extensão da informação, a variedade das fontes de acesso, com o aprofundamento da sua compreensão, em espaços menos rígidos, menos engessados". Este é o papel da EAD, e somente dentro dessa perspectiva é que a modalidade poderá atender com qualidade aos estudantes. 
A EAD tem como vantagens a oferta de cursos flexíveis e autoinstrucionais; oportunidade de continuação dos estudos para àqueles que estão distantes geograficamente dos grandes centros; pessoas com necessidades especiais temporárias ou permanentes; educação de adultos e atendimento à demanda por formação continuada (MADEIRA, 2006; ALMEIDA, 2003). A formação continuada tem na EAD grande oportunidade para que professores e bibliotecários participem de cursos para desenvolver o letramento informacional e, consequentemente, a competência em informação.

\subsection{MODELO CONCEITUAL}

A fim de representar graficamente a relação entre os quatro conceitos fundantes da pesquisa, foi elaborado o modelo teórico. De acordo com ele, a sociedade da aprendizagem requer indivíduos com condições de aprender a aprender ao longo da vida. A necessidade do aprendizado constante leva à busca pela formação continuada, com o objetivo de especialização e também de suprir possíveis lacunas da graduação. Tal formação pode ser realizada a distância, por meio de cursos de EAD oferecidos pelas universidades públicas do país. No caso dessa pesquisa, foi utilizado para análise o curso de especialização denominado "Letramento Informacional: educação para a informação - CELI". O curso consta de 400 horas e foi oferecido pela Universidade Federal de Goiás, durante o período de Agosto de 2014 a Dezembro de 2015. O curso contou com a matrícula inicial de 139 estudantes e a participação de 19 professores autores e 19 tutores a distância.

Após a conclusão da formação continuada em LI, questionamos: os participantes adquiriram o domínio dos conceitos e práticas da competência em informação? É possível por meio do curso de EAD obter os conhecimentos necessários ao desenvolvimento da competência em informação? A figura 7 a seguir demonstra em um esquema visual como a relação entres esses elementos é estabelecida. 
Figura 7 - Modelo Conceitual da pesquisa

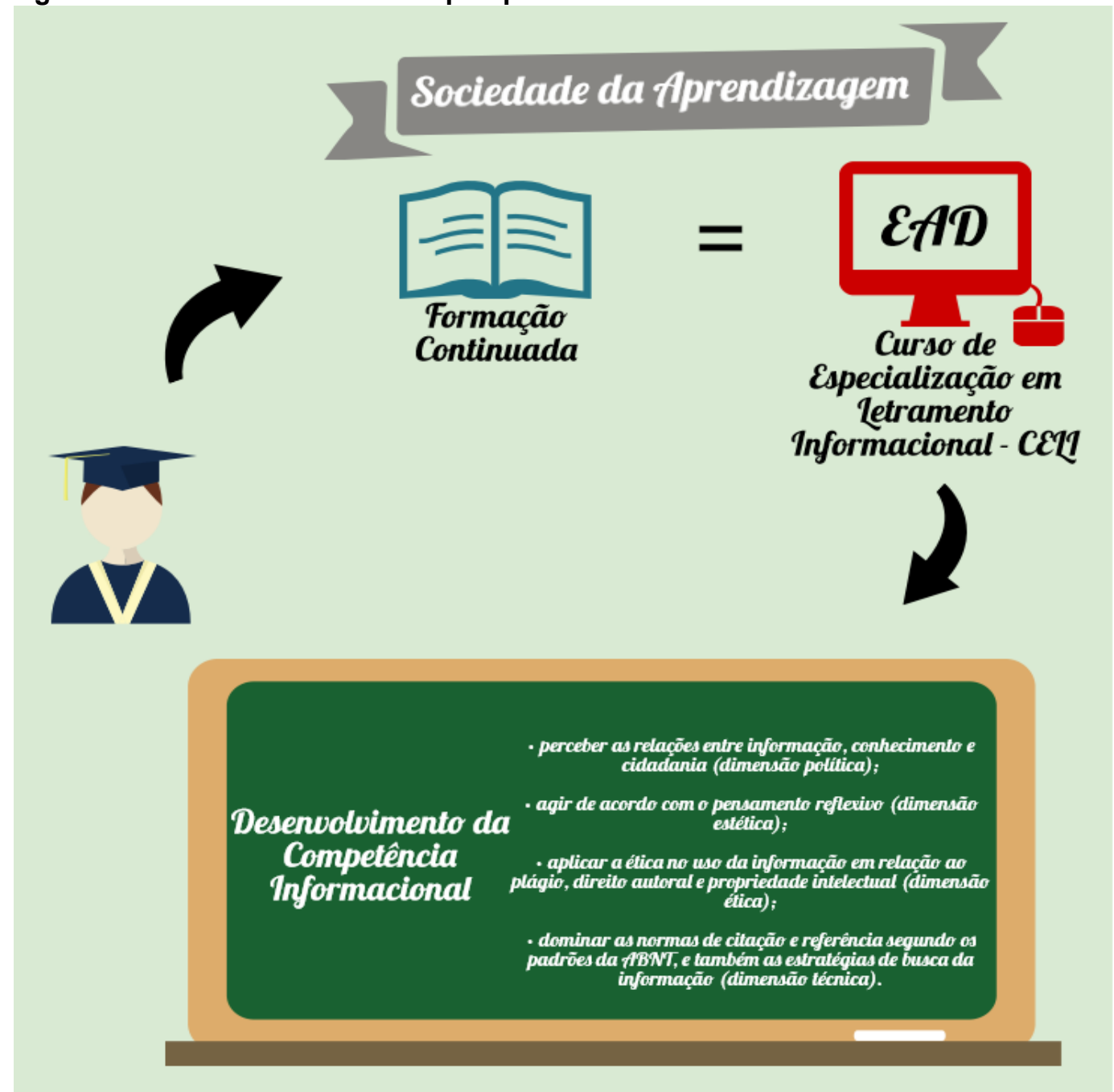

Fonte: Elaboração própria (2015). 


\section{CAPÍTULO 7 \\ MÉTODO DA PESQUISA}

Este capítulo tem como propósito descrever os caminhos percorridos para a elaboração da pesquisa. Apresenta os métodos e técnicas adotados para alcançar os objetivos.

\subsection{PERCURSO METODOLÓGICO}

O método adotado em uma pesquisa pode ser compreendido como a descrição das etapas utilizadas para alcançar os objetivos propostos, valendo-se de diversas estratégias que o pesquisador julgar como mais adequadas. Tal ideia é compartilhada por Tomanik (2004), que acredita que métodos bem fundamentados e com descrições detalhadas dos caminhos percorridos, favorecem o desenvolvimento de afirmações e possibilitam avaliá-las.

A pesquisa teve como objetivo geral analisar os elementos da formação continuada em Letramento Informacional que podem impactar no desenvolvimento da competência em informação de professores e bibliotecários. Para tanto, utilizou-se como base empírica o curso de especialização intitulado "Letramento Informacional: educação para a informação" - CELI. Tal curso foi ofertado pela Universidade Federal de Goiás na modalidade a distância de Agosto de 2014 a Dezembro de 2015 por meio do Centro Integrado de Aprendizagem em Rede - CIAR, o qual oferece diversos cursos de especialização latu sensu em parceria com a UAB/CAPES.

A pesquisa caracteriza-se como estudo de caso, o qual é definido como "estudo profundo e exaustivo de um ou de poucos objetos, de maneira a permitir o seu conhecimento amplo e detalhado" (GIL, 2014, p.57). A escolha do curso deu-se pelo fato de a pesquisadora fazer parte do corpo docente, atuando na produção de conteúdos e como tutora de três disciplinas, o que possibilitou contato com os estudantes e acesso à plataforma moodle na qual o curso ocorreu. 
Utilizamos dois métodos e três estratégias para a coleta de dados: análise de conteúdo das atividades desenvolvidas pelos estudantes; análise da estrutura do curso e do projeto político pedagógico e avaliação do curso pelos participantes. O último objetivo consiste na proposição de diretrizes para cursos de formação continuada em Letramento Informacional na modalidade EAD, que será feito a partir da análise dos dados obtidos. No quadro 3 podemos visualizar a relação entre os objetivos, o método e as fontes de coleta de dados utilizadas.

\section{Quadro 3 - Relação entre objetivos e métodos}

\begin{tabular}{|l|l|l|}
\hline \multicolumn{1}{|c|}{ OBJETIVOS ESPECÍFICOS } & \multicolumn{1}{|c|}{ MÉTODO UTILIZADO } & \multicolumn{1}{|c|}{ FONTE DE COLETA DE } \\
DADOS
\end{tabular}

Fonte: elaboração própria (2016).

A seguir explicamos detalhadamente cada uma das etapas e métodos utilizados.

\subsection{DELIMITAÇÃO DO ESTUDO}

O campo de estudo da pesquisa, como dito anteriormente, é o Curso de Especialização em Letramento Informacional: a educação para a informação. Para compreender a estrutura e funcionamento dele, torna-se fundamental apresentar as principais informações do curso. 
O referido curso tem como objetivo principal ${ }^{14}$ "contribuir para a promoção, no âmbito escolar, de uma educação voltada para a informação, observando-se os aspectos técnicos, éticos, legais e pedagógicos envolvidos na prática informacional, de forma articulada à proposta pedagógica e à concepção de uma aprendizagem contínua e autônoma" (CELI, 2014). Ou seja, é uma importante iniciativa para possibilitar não apenas a capacitação dos profissionais que lidam com educação, mas também de contribuir para que a sociedade da aprendizagem se efetive.

A estrutura pedagógica do curso foi baseada nas quatro dimensões da competência em informação, sugeridas por Vitorino e Piantola (2011), quais sejam, a política, a ética, a estética e a técnica. A equipe que elaborou o projeto político pedagógico foi composta por três professoras do curso de Biblioteconomia da UFG, com o apoio de outros sete professores da instituição, dentre os quais a pesquisadora dessa tese. Além disso, também contou com a participação de professores da Universidade de Brasília - UNB. O curso foi uma iniciativa realizada com objetivo de preencher a lacuna na formação de professores e bibliotecários para atuarem como mediadores do letramento informacional na escola.

Dessa forma, percebemos como seria enriquecedor estudar a estrutura pedagógica e a concepção do curso, bem como os resultados alcançados ao longo do processo de formação dos participantes. Os dados produzidos pelos estudantes nas disciplinas foram muito interessantes e mereceram análise detalhada. Além disso, a escolha do CELI como base empírica deve-se ao fato de o curso ter sido estruturado com base nas quatro dimensões da competência em informação, que é a linha de análise que se pretende adotar na pesquisa. Assim, surgiu a ideia de utilizar a estrutura do curso e também as atividades pedagógicas desenvolvidas, transformando-as em dados de pesquisa.

\footnotetext{
${ }^{14}$ Informações disponíveis no tópico apresentação do curso no endereço: http://celi.ciar.ufg.br/
} 


\subsubsection{População estudada}

A população estudada foi composta por todos os estudantes participantes do CELI - professores e bibliotecários. Ingressaram no curso 139 alunos, dos quais 92 professores, 19 bibliotecários e outros 28 estudantes com formações variadas. De acordo com dados da secretaria do curso, no momento da realização da coleta de dados da pesquisa, havia 95 estudantes ativos. Desses, 56 eram professores e 18 eram bibliotecários, totalizando 74 participantes, que compõem o universo da pesquisa. Todos eles tiveram a oportunidade de responder ao questionário avaliativo sobre o curso, enviado por email pela secretaria do CELI. Para a análise de conteúdo, utilizouamostragem aleatória simples para selecionar os participantes, a qual consiste em "atribuir a cada elemento da população um número único para depois selecionar alguns desses elementos de forma casual” (GIL, 2014, p.91). Desse modo, foram selecionados dezesseis professores e bibliotecários avaliados, resultando em uma análise de trinta e duas atividades, o que corresponde a uma amostra de $43 \%$ dos participantes.

\subsubsection{Método e técnica adotados}

A primeira etapa da pesquisa foi a construção de revisão teórica para fundamentar o tema discutido, a fim de elucidar os conceitos-chave e também apontar para a metodologia mais adequada aos objetivos do estudo. A partir do referencial teórico, percebemos a importância de trabalhar com mais de uma metodologia, por serem complementares. Sendo assim, utilizamos as abordagens quanti e qualitativas, pois congrega dados obtidos por meio de questionário fechado analisado estatisticamente, como também empregou análise de conteúdo de documentos.

O método qualitativo tornou-se mais adequado à pesquisa por possibilitar análise mais abrangente. Essa abordagem vale-se da percepção e da subjetividade do pesquisado e do pesquisador. Por meio da análise de conteúdo dos documentos, foi possível identificar o domínio dos conceitos do letramento informacional pelos 
participantes do curso, bem como a aplicação prática desses, o que seria a competência propriamente dita.

Avaliar não é tarefa fácil, requer parâmetros bem definidos e planejamento. A avaliação do nível de competência em informação de indivíduos e grupos é fundamental para que estratégias educacionais e organizacionais sejam modificadas e novas ações sejam planejadas, a fim de melhorar a aprendizagem e a geração de novos conhecimentos. Porém, ressaltamos que, na maioria das vezes, realiza-se avaliação dos aspectos técnicos da competência, excluindo outras facetas fundamentais, como a ética, a estética e a política. Sendo assim, utilizamos como método para aferir a competência a análise de conteúdo das atividades realizadas pelos estudantes, possibilitando a avaliação da compreensão dos conceitos bem como a aplicação prática.

$\mathrm{Na}$ análise de conteúdo, utilizamos como base o referencial desenvolvido por Vitorino e Piantola (2011) que considera a competência em informação em quatro dimensões, como mencionada anteriormente. A análise de conteúdo foi realizada por níveis de competência.

\subsubsection{Instrumentos de coleta de dados}

Para que os objetivos pudessem ser alcançados, optou-se por trabalhar com três estratégias para a coleta de dados, que foram, análises de conteúdo de atividades produzidas pelos estudantes e do projeto político pedagógico do curso, análises do Ambiente Virtual de Aprendizagem (AVA) utilizado e do questionário avaliativo ao final do curso. Cada uma das estratégias foi detalhada a seguir. 


\title{
7.2.3.1 Análise de conteúdo
}

A análise de conteúdo é um método qualitativo que consiste na utilização de documentos, comunicações, cartas, entrevistas a fim de analisar o conteúdo. Para Cunha (1982)

\begin{abstract}
A Análise de conteúdo tem sido usada para determinar a ênfase relativa ou a frequência de vários fenômenos da comunicação, tais como: estilo, tendências, propaganda, mudança no conteúdo, legibilidade, riqueza de vocabulário, etc. Esse método é bastante diferente dos outros tipos de pesquisa porque, em lugar de entrevistar ou observar pessoas, o pesquisador trata com registros já existentes e faz inferências a partir deles. Esses registros podem ser cartas, conversações pessoais, entrevistas não estruturadas, livros, programas de televisão, documentos pessoais, poemas, jornais, artigos, etc. (CUNHA, 1982, p.15).
\end{abstract}

De acordo com Bardin (2011, p.125), o referido método é dividido em fases, quais sejam:

- pré-análise;

- exploração do material;

- tratamento dos resultados, a inferência e a interpretação.

As fases foram explicadas a partir do próximo tópico e relacionadas com a pesquisa.

\section{Pré-análise}

Nesta etapa foram escolhidos os documentos submetidos à análise, além da formulação das hipóteses e dos objetivos e a elaboração de indicadores para fundamentação da interpretação final. Os documentos selecionados foram atividades pedagógicas desenvolvidas no CELI em cada um dos eixos, bem como o projeto político-pedagógico. 
O primeiro eixo do curso tratou da dimensão teórico-conceitual do LI, constituída em 3 módulos: sociedade da informação, competência em informação e letramento informacional. Dentro de cada módulo, foram realizadas várias atividades. Para o propósito da identificação dos aspectos políticos da competência, selecionamos atividade proposta no módulo "Sociedade da Informação". Na atividade foi solicitada a produção textual que representasse a percepção do estudante acerca da sociedade. A análise da atividade possibilitou a compreensão dos aspectos políticos da $\mathrm{Cl}$.

O segundo eixo do curso tratou da dimensão estética em dois módulos denominados "Teoria sobre aquisição e desenvolvimento da linguagem" e "Pensamento reflexivo e produção de conhecimento". No eixo, foi selecionada atividade realizada no segundo módulo, pois o pensamento reflexivo é a base da educação voltada para a estética. A atividade escolhida solicitava ao estudante, a partir de leituras prévias acerca do tema, apresentação de situação do cotidiano em que fosse possível usar o pensamento reflexivo. $O$ estudante descreveu cada fase com as ações empreendidas para resolver o problema.

O terceiro eixo do curso não se relaciona com os propósitos da pesquisa, portanto não foi avaliado. $O$ quarto eixo trata da dimensão ética da competência em informação. Nesse eixo, havia apenas um módulo, intitulado "Ética da informação". A atividade avaliativa consistiu na elaboração de um conto com os temas trabalhados na disciplina tais como ética na contemporaneidade, liberdade de expressão, plágio e autoria. Os trabalhos selecionados foram avaliados de acordo com a adequação do conteúdo aos princípios da dimensão ética da competência.

No quinto e último eixo do curso, o tema foi a dimensão técnica da competência em informação, que contou com cinco módulos: Comunicação científica; Ambientes colaborativos; Normalização do trabalho acadêmico; Busca pela informação e Organização da informação. Dentre esses, foi escolhida para análise a atividade desenvolvida no módulo sobre Busca pela Informação, por ser a mais relacionada à dimensão técnica da competência. A atividade solicitada envolveu cinco etapas 
orientadas pelas docentes responsáveis pela disciplina, que abrangeram: identificação da necessidade de informação, seleção da fonte mais adequada, aplicação dos critérios de qualidade para fontes de informação, seleção de estratégias de busca e avaliação dos resultados obtidos.

\section{Hipótese}

A formação básica de professores e bibliotecários (graduação) não é o suficiente para que consigam aplicar a competência em informação na vida profissional e pessoal. Após finalizarem o curso de formação continuada em letramento informacional são capazes de:

- perceber as relações entre informação, conhecimento e cidadania (dimensão política);

- agir de acordo com o pensamento reflexivo (dimensão estética);

- aplicar a ética no uso da informação em relação ao plágio, direito autoral e propriedade intelectual (dimensão ética);

- buscar, avaliar e utilizar a informação aplicando estratégias de busca e recuperação da informação adequadas (dimensão técnica).

Os indicadores utilizados para análise foram aqueles sugeridos na revisão da literatura sobre as dimensões da $\mathrm{Cl}$. Cada dimensão possui características que determinam se o indivíduo possui ou não competência em informação, e a partir dessas analisamos as tarefas descritas anteriormente.

\section{Exploração do material}

$\mathrm{Na}$ fase de exploração do material ocorreu a decodificação do material propriamente dita, composta por anotações, leituras, transformação em enunciados, categorização. Enfim, essa fase é a de organização do material para a análise. Foi solicitado à coordenação do curso acesso para selecionar as atividades de cada 
módulo. Com a permissão, selecionaram-se as tarefas aleatoriamente tomando o cuidado de que cada estudante fosse selecionado apenas uma vez. Com o material em mãos passou-se ao agrupamento das tarefas de cada módulo para posterior análise.

\section{Tratamento dos resultados, inferência e interpretação}

Para o tratamento dos dados, utilizou-se a divisão do conteúdo em quatro dimensões da competência em informação, e à medida que as inferências foram sendo realizadas, algumas subdivisões ocorreram. O conteúdo foi analisado de acordo com as características dessas dimensões, bem como a partir das relações estabelecidas com o referencial teórico construído na tese. A apresentação dos resultados foi feita por meio de análise e agrupamentos em forma de tabelas, gráficos, esquemas, quadros e estatísticas de frequência.

Dentre as técnicas possíveis de serem empregadas para a análise de conteúdo, utilizamos a análise temática, que permite a identificação de núcleos de sentido do texto. A presença/ausência de determinados temas ou a frequência deles podem significar algo, e também mostrar a intensidade do conteúdo, tempo verbal, adjetivos, qualificadores, tudo o que determinar a ênfase do discurso (BARDIN, 2011).

\subsubsection{Análise da Estrutura e Projeto político pedagógico do curso}

A análise da estrutura e do projeto político pedagógico do curso foi fundamental para identificar os aspectos positivos, negativos e aqueles que podem ser melhorados para possível próxima edição ou ainda para servir como base para outros cursos de especialização na área de letramento informacional.

Após leitura detalhada de todo o PPP foram extraídas as informações referentes aos aspectos: estrutura curricular e pedagógica, equipe, material didático e estratégias de ensino e ambiente virtual de aprendizagem. A técnica empregada foi a análise de 
conteúdo, destacando as informações mais relevantes sobre cada um dos aspectos mencionados.

\subsubsection{Questionário estruturado Avaliativo do Curso}

Ao final do curso foi aplicado questionário avaliativo (apêndice 1) da estrutura. $O$ questionário conteve questões relacionadas ao objetivo geral da pesquisa, que buscou a identificação dos elementos de formação continuada em Letramento Informacional com potencial para impactar o desenvolvimento de competência em informação dos professores e bibliotecários. Isso requereu a análise da estrutura pedagógica, tecnológica e didática, a fim de perceber de que forma os elementos influenciaram na aprendizagem e no desempenho do estudante. Foi elaborado a partir da identificação dos itens mais relevantes em cursos EAD por meio da percepção da pesquisadora e da revisão teórica da tese.

O instrumento foi desenvolvido no Google Docs, plataforma que permite aos participantes responder eletronicamente e gerar os gráficos de forma automática. Ficou disponível entre os dias 10 a 25 de novembro de 2015. O conteúdo contemplou questões relativas a:

- bloco 1 - estrutura político pedagógica do curso (8 questões);

- bloco 2 - docentes (6 questões);

- bloco 3 - material didático e estratégias de ensino (5 questões);

- bloco 4 - metodologias de avaliação do desempenho (3 questões);

- bloco 5 - tutoria (5 questões);

- bloco 6 - ambiente virtual de aprendizagem (moodle) (5 questões), totalizando 32 questões.

O questionário utilizou escala do tipo Likert de 6 pontos em que 1 corresponde a péssimo e 6 a excelente. No quadro 4, é possível observar como a avaliação foi aferida. Nos quesitos em que a maior parte das respostas concentrou-se nos níveis 1 ou 2 a 
avaliação foi considerada negativa; quando centrada nos níveis 3 ou 4 foi considerada regular e quando em 5 ou 6 , positiva.

Quadro 4 - Medidas de avaliação do curso

\begin{tabular}{|l|l|}
\hline PONTOS DA ESCALA & AVALIAÇÃO DO CURSO \\
\hline 1 Péssimo & Negativa \\
\hline $\begin{array}{l}\text { 3 Razoável } \\
\text { 4 Bom }\end{array}$ & Regular \\
\hline $\begin{array}{l}\text { 5 Muito bom } \\
6 \text { Excelente }\end{array}$ & Positiva \\
\hline
\end{tabular}

Fonte: elaboração própria (2015).

Além de identificar a percepção dos estudantes sobre o curso, a competência em informação dos participantes, e descrever as características do CELI, apresentamos diretrizes para a formação continuada em EAD, e para tanto foi preciso concluir todas as etapas e objetivos anteriores para ter os subsídios necessários a essa reflexão e consequente proposição. 


\section{CAPÍTULO 8}

\section{ANÁLISE E DISCUSSÃO DOS RESULTADOS}

Neste capítulo apresentamos a análise dos dados coletados a partir das atividades desenvolvidas pelos estudantes no decorrer da especialização em Letramento Informacional, como também a análise da percepção deles sobre o curso. Como objeto de análise também utilizou-se o projeto político pedagógico do curso e o ambiente virtual de aprendizagem (AVA), a fim de compreender a dinâmica e o modo como foi conduzido.

\subsection{ANÁLISE DA COMPETÊNCIA EM INFORMAÇÃO DOS PARTICIPANTES DO CELI}

A análise da competência em informação dos participantes do CELI se deu a partir de dados coletados nas tarefas desenvolvidas pelos estudantes em quatro diferentes módulos do curso. Tais atividades estão relacionadas às quatro dimensões da competência em informação propostas por Vitorino e Piantola (2011), quais sejam, política, estética, ética e técnica. Cada dimensão foi dividida em categorias de análise, de acordo com o conteúdo trabalhado em cada módulo. A técnica empregada para análise dos dados consistiu em análise de conteúdo a partir da verificação da frequência com que o discurso se repetiu nas atividades, e também por agrupamentos das ideias fundamentais contidas nos textos. Por questões de sigilo, optou-se por trocar o nome dos pesquisados por letras do alfabeto.

\subsubsection{Dimensão política}

A primeira atividade selecionada consistiu na discussão sobre o aspecto político da competência em informação. A dimensão política refere-se à capacidade do indivíduo de atuar na sociedade da informação de forma crítica, com competência para avaliar os conteúdos disponíveis na sociedade. O acesso à informação e ao conhecimento passa a ser condição básica para o exercício da cidadania, por se 
constituir como elemento fundamental para promover mudanças. Mais do que acesso, é preciso que o usuário saiba utilizar a informação para atender aos propósitos a partir da reflexão, interpretação e construção de significados (VITORINO; PIANTOLA, 2011). Aquele que desenvolve a competência no aspecto político, estará apto a desempenhar as atividades:

- Exercer a cidadania por meio da informação.

- Participar nas decisões e transformações da vida social.

- Ser capaz de ver além da superfície do discurso.

- Considerar que a informação é produzida a partir de um contexto específico.

A tarefa selecionada para avaliar essa dimensão foi realizada no Eixo 1 Teórico-Conceitual. O módulo em questão denominava-se Sociedade da Informação, e teve como objetivo introduzir a temática e familiarizar os estudantes com o contexto do curso. A atividade solicitava que produzissem um texto dissertativo que agregasse os principais conceitos sobre o tema: Sociedade da Informação - Mitos e verdades, no qual deveriam expressar a compreensão acerca do que foi discutido no módulo. Antes de produzir o texto foram, os estudantes incentivados a participar do fórum de discussão e realizar as leituras sugeridas para ampliar o conhecimento sobre o assunto.

O material produzido foi postado no moodle por todos os estudantes, e dentre esses, oito foram escolhidos de forma aleatória para serem analisados na pesquisa, sendo quatro de bibliotecários e quatro de professores. A análise foi realizada a partir de leitura cuidadosa dos textos, observando-se a adequação do conteúdo às características fundamentais da competência no aspecto político.

Após a primeira leitura, seguiu-se outra leitura detalhada na qual as ideias centrais foram grifadas, agrupadas e transformadas em palavras-chave, que representaram o conteúdo analisado. No quadro 5 , a seguir, demonstramos a estratégia utilizada para analisar o conteúdo de cada um dos textos produzidos e a seleção dos termos mais relevantes. 
Quadro 5 - Modelo de análise de conteúdo adotado na pesquisa

\begin{tabular}{|c|c|}
\hline Fragmento do texto produzido & Termos selecionados \\
\hline $\begin{array}{l}\text { As informações, na contemporaneidade, } \\
\text { circulam de maneira rápida e intensa. Com o } \\
\text { advento das novas tecnologias, principalmente } \\
\text { com a chegada da internet, as informações têm } \\
\text { se disseminado ainda mais facilmente. Assim, } \\
\text { cria-se uma impressão de que elas se } \\
\text { propagam pela rede de maneira instantânea e } \\
\text { fluída. Em contrapartida, se de um lado temos } \\
\text { tal acessibilidade, do outro nos esbarramos } \\
\text { com várias problemáticas quanto o assunto em } \\
\text { voga é o ato de se comunicar. }\end{array}$ & $\begin{array}{l}\text { Novas tecnologias; } \\
\text { Internet; } \\
\text { Disseminação da informação de forma rápida e } \\
\text { intensa; } \\
\text { Barreiras na comunicação. }\end{array}$ \\
\hline
\end{tabular}

Fonte: elaboração própria (2015).

Desse modo, ao analisar o conteúdo das atividades selecionadas chegamos a alguns termos que apareceram com maior frequência. Os termos foram separados em categorias. A primeira categoria refere-se à Informação e cidadania; a segunda referese à relação entre Informação e poder; a terceira e última categoria refere-se à Informação e tecnologia, envolvendo os aspectos que caracterizam essa relação. As categorias e os respectivos termos ficaram assim representadas:

Quadro 6 - Análise de conteúdo da dimensão política da competência em informação

\begin{tabular}{|l|l|}
\hline \multicolumn{1}{|c|}{ CATEGORIAS } & \multicolumn{1}{|c|}{ TERMOS RELACIONADOS } \\
\hline 1 - Informação e Cidadania & $\begin{array}{l}\text { Educação para a informação; formação profissional } \\
\text { adequada; atuação conjunta de bibliotecários e } \\
\text { professores; formação de cidadãos reflexivos e críticos; } \\
\text { inclusão digital; letramento e competência em } \\
\text { informação. }\end{array}$ \\
\hline 3 - Informação e poder & $\begin{array}{l}\text { Exclusão; veracidade da informação; qualidade da } \\
\text { informação; inforricos; infopobres; informação como } \\
\text { mercadoria; manipulação da informação; } \\
\text { democratização do acesso; analfabetos digitais; } \\
\text { capitalismo. }\end{array}$ \\
\hline 4 - Informação e tecnologia & $\begin{array}{l}\text { Tecnologia; Tics; globalização; excesso de informação; } \\
\text { disseminação da informação; acesso à informação; } \\
\text { Internet; atualização das informaçães; velocidade da } \\
\text { informação; EAD; irrelevância da informação. }\end{array}$ \\
\hline
\end{tabular}

Fonte: dados da pesquisa (2015).

Os termos citados mais frequentes no texto dos professores estão ligados à relação entre informação e poder. Eles envolvem a exclusão das pessoas na sociedade da informação, a forma como a tecnologia permeia o cotidiano, o excesso de 
informação e a formação de cidadãos críticos e reflexivos para atuarem nessa sociedade.

Nos textos dos bibliotecários aparecem, em primeiro lugar, o impacto da tecnologia no cotidiano, em seguida, a importância da formação de cidadãos críticos e reflexivos, o excesso de informação disponível e a democratização do acesso para que maior número de pessoas efetivamente participe da sociedade. O trecho do texto do bibliotecário 'A', por exemplo, demonstra preocupação com a importância da educação e da formação continuada de professores para lidar com a situação na sala de aula, destacando que, às vezes, nem o próprio profissional tem conhecimento sobre como agir de acordo com as demandas da sociedade da informação.

\begin{abstract}
"Nesse contexto a educação tem papel primordial para transferências de conhecimento. O indivíduo muitas vezes não se preocupa com a origem das informações que obtém. Por outro lado, os professores estão despreparados. $O$ estado não investe em formação continuada com isso o desafio é superar as antigas deficiências e criar as novas técnicas. É necessário investir na formação de profissionais que desenvolvam um trabalho de qualidade e incentivem a pesquisas em seus alunos, pois em muitos casos até o próprio educador não utiliza desse procedimento" (BIBLIOTECÁRIO A).
\end{abstract}

De um modo geral, o discurso dos dois profissionais é semelhante. $O$ fato de as TICs aparecerem no texto de todos os bibliotecários justifica-se pelo fato de o profissional lidar com as mesmas no cotidiano como instrumento de trabalho. Por isso, talvez percebam o impacto dessas com maior intensidade.

Os professores demonstram a relação entre informação e poder com muita propriedade, deixando claro como isso deixa as pessoas à margem da sociedade $\mathrm{e}$ promove desigualdades sociais. Isso pode ser confirmado no trecho do texto do professor 'B':

"Logo, a informação que circula, algumas vezes, é manipulada para servir ao interesse de poucos. À medida que não há interesse em formar uma sociedade crítica e questionadora de seus direitos. A informação relevante e verdadeira não é gratuita, pelo contrário, ela tem um custo, ficando restrita há poucos e logo não é disseminada entre as massas" (PROFESSOR B). 
O poder da informação, segundo Cuevas-Cervero; Marques; Paixão (2014, p.36) "reside em sua potencialidade, potencialidade que nem todos temos a oportunidade de atualizar, o que é um problema, porque a informação é um elemento vital em muitos sentidos, e um deles é a participação cidadã nas instituições e na consolidação de uma verdadeira democracia". Na mesma linha Demo (2000), argumenta que como a informação se tornou mercadoria, informa-se bem menos do que deveria, devido à manipulação dos meios de comunicação. Assim sendo, o letramento informacional apresenta-se como ferramenta emancipatória para que os indivíduos alcancem autonomia.

Dois bibliotecários e um professor mencionaram como fundamental a parceria entre os dois profissionais para a consolidação do movimento da competência em informação, demonstrando assim entendimento em relação à importância da atuação de ambos na escola. É possível perceber nos textos a preocupação com a formação de cidadãos críticos e reflexivos, preparados para atuar em sociedade e capacitados a selecionar conteúdos de qualidade a partir de capacitação em letramento informacional, como podemos perceber no texto do bibliotecário ' $\mathrm{C}$ ':

"Inclusão digital, destacada no eixo temático, que não pode ser apenas fornecer acesso a internet aos cidadãos, deve-se capacitar o cidadão para apreensão e apropriação crítica dos conteúdos do ciberespaço para a produção de novos conhecimentos e novas realidades. Se associada ao letramento informacional, a inclusão digital irá capacitar cidadãos pesquisadores capazes de pesquisar, fazer o uso ético da informação e a interação e o compartilhamento de seus achados através do domínio de determinadas regras de comunicação científica escrita e oral. Destacando-se que a efetividade dos programas de letramento nas escolas só será possível através da parceria entre professores e bibliotecário" (BIBLIOTECÁRIO C).

A compreensão e, consequente, aplicação da competência em informação em relação à dimensão política é fundamental para a informação ser utilizada de maneira transformadora no cotidiano das pessoas e nas relações sociais. Por tal motivo, os investimentos em educação e cultura são básicos. Cuevas-Cervero; Marques; Paixão (2014) explicam que mesmo que tais investimentos ocorram, ainda acontecem muito aquém das demandas da sociedade, pois a tecnologia e a comunicação se desenvolvem de maneira muito mais rápida. 
Importante ressaltar que no projeto político pedagógico do curso destaca-se que "não se contemplam de forma direta os conteúdos propostos para o eixo político uma vez que os tópicos que os compõe são tratados de forma transversal nos demais eixos, sendo amparado pelo eixo teórico-conceitual, dentro da temática Sociedade da Informação" (PPP CELI, 2013). Tal premissa confirma a necessidade de se trabalhar essa dimensão de maneira ampla ao longo do curso, e que os conceitos trabalhados nesse módulo servem apenas como direcionamento para que a discussão possa se aprofundar em outros momentos.

Evidencia-se nos textos produzidos pelos participantes, que em alguns aspectos, há o entendimento do que vem a ser comportamento político, de acordo com os indicadores da competência em informação, mas em outros é necessário trabalhar mais profundamente. Percebemos que, com apenas uma atividade não é possível afirmar que são competentes ou não em tal aspecto, mas entendemos que são níveis de competência, em que a pessoa pode estar mais apta em determinada atividade e menos em outra.

Concluímos com as análises da atividade, que em relação à dimensão política da competência em informação, os professores e bibliotecários demonstraram conhecimento e compreensão necessárias de algumas facetas que envolvem tal dimensão, como a relação entre informação e poder e informação e cidadania. Contudo, ressaltamos que para verificar efetivamente a competência política outras atividades precisariam ser desenvolvidas. Por ter sido a primeira disciplina do curso e a primeira atividade realizada pelos estudantes, percebeu-se algumas dificuldades de compreensão e apresentação das ideias, talvez por ainda não estarem familiarizados com o tema.

\subsubsection{Dimensão estética}

A dimensão estética da competência, de acordo com Vitorino e Piantola (2011), é aquela inspirada no processo criativo, que expressa a capacidade individual de 
reflexão e sensibilidade ao lidar com o mundo. Espera-se que o indivíduo competente em informação seja capaz de:

- Desenvolver criatividade sensível.

- Compreender, relacionar, ordenar, configurar e ressignificar a informação.

- Expressar sua experiência interior individual e única ao lidar com os conteúdos de informação e sua maneira de expressá-la e agir sobre ela no âmbito coletivo.

A atividade selecionada para análise foi extraída do módulo Pensamento Reflexivo e Produção do conhecimento, parte do Eixo 2 - Dimensão Estética. De acordo com instruções das docentes responsáveis, o estudante, a partir de leituras prévias de materiais disponibilizados sobre o pensamento reflexivo e a relação com o letramento informacional, debates nos fóruns e ao assistir aos vídeos também sobre o tema, apresentasse situação do cotidiano em que fosse possível usá-lo, descrevendo cada fase com as ações empreendidas para resolver o problema. Os estudantes elaboraram a atividade na segunda semana da disciplina, o que possivelmente possibilitou maior tempo para estudo e familiarização com o conteúdo e também debates mais aprofundados com os colegas, o que daria mais subsídios na execução da tarefa.

A tarefa deveria ser elaborada a partir das seguintes instruções:

1. as sugestões: ideias que surgem da observação ou lembranças evocadas, em que se definem planos e estratégias para uma possível solução;

2. intelectualização: formulação da pergunta, visando situar com exatidão o problema;

3. a ideia-guia ou hipótese: uso de sugestões para orientar as observações e operações durante a coleta de dados;

4. o raciocínio: elaboração mental da ideia, ou a suposição de que o exame completo da ideia permite fornecer termos intermediários que ligam os elementos de forma consistente; 
5. a verificação da hipótese: realizada mediante provas, caso os resultados correspondam com os que foram deduzidos teórica ou racionalmente e se somente as condições em questão forneceriam tais resultados. Nesses casos, a confirmação é tão forte que induz a uma conclusão até que novos fatos indiquem outra revisão.

De posse dessas orientações, os estudantes produziram roteiro com a descrição de atividade cotidiana com a utilização do pensamento reflexivo, observando cada uma das etapas. Após análise das atividades, chegamos às ações empreendidas pelos mesmos para solucionar o problema. Tais ações foram agrupadas em três categorias: a primeira foi o planejamento, levando em consideração a criatividade; a segunda o uso da informação para a definição de estratégias; e a terceira foi a solução para o problema de acordo com os conhecimentos do indivíduo a respeito da situação. Os resultados podem ser observados no quadro 7 .

Quadro 7 - Análise de conteúdo da dimensão estética da competência em informação

\begin{tabular}{|l|l|}
\hline \multicolumn{1}{|c|}{ CATEGORIAS } & POSICIONAMENTO DOS PARTICIPANTES \\
\hline 1 - Planejamento & $\begin{array}{l}\text { Verificar alternativas; análise baseada em } \\
\text { critérios; identificação da situação problema. }\end{array}$ \\
\hline 2 - Definição e uso da informação & $\begin{array}{l}\text { Identificar necessidade de informação; } \\
\text { levantamento de prós e contras; escolha de } \\
\text { fontes seguras; reunão de informações } \\
\text { relevantes. }\end{array}$ \\
\hline 3 - Solução do problema & $\begin{array}{l}\text { Tomada de decisão segura; escolha da } \\
\text { alternativa mais viável; reflexão sobre o } \\
\text { melhor caminho. }\end{array}$ \\
\hline
\end{tabular}

Fonte: dados da pesquisa (2015).

Importante salientar que a busca e o uso da informação em qualquer circunstância deve considerar que $\mathrm{O}$ indivíduo traz consigo valores, crenças e motivações durante o processo. A capacidade crítica e estoques de conhecimentos também influenciarão nesse percurso (GASQUE, 2012).

Por meio dos resultados obtidos na análise do conteúdo identificou-se primeiramente entre os professores, que os quatro compreenderam como realizar a 
atividade, abordando-a de acordo com as etapas necessárias. Em dois casos, a tomada de decisão ocorreu baseando-se em conhecimentos prévios, sem recorrer a outras fontes de informação, ainda que mais de uma alternativa para solucionar a questão tenha sido levantada. Nos outros dois casos, os pesquisados buscaram por informações em fontes que pudessem auxiliá-los, minimizando os riscos de agir baseando-se apenas na intuição. Isso indica que ambos utilizaram o pensamento reflexivo nas atividades, porém aqueles que buscaram informação além do próprio conhecimento, demonstram preocupação em assegurar que a decisão fosse tomada de forma mais fundamentada. Em uma das atividades o professor foi bastante detalhista, evidenciando, inclusive, a importância de checar as fontes de informação para assegurar a confiabilidade, como podemos perceber no trecho a seguir:

\begin{abstract}
"A escolha de sites confiáveis nos darão maior segurança, no momento de aprovar ou reprovar o cadastro do cliente. Deve-se selecionar e acessar as informações adequadamente não queimando etapas. Será preciso avaliar criticamente as informações e suas fontes e usar a informação ética e legalmente para atingir os objetivos específicos, não mascarando nem manipulando essas informações para satisfazer a necessidades pessoais do cliente pesquisado" (PROFESSOR E).
\end{abstract}

Outro exemplo demonstra que ao se deparar com o problema, houve reflexão e pesquisa sobre o que deveria ser feito, buscou-se a melhor alternativa e colocou-a em ação. Houve ainda oportunidade de aplicar as informações obtidas e avaliar os resultados. Ainda que as etapas não tenham sido descritas separadamente de acordo com o roteiro, ambas estão presentes na situação citada. O trecho a seguir, extraído da atividade de um professor, ilustra a situação-problema e o percurso utilizado para solucioná-la.

"Havia um aluno na escola com paralisia cerebral e ninguém sabia como ensiná-lo, observei o aluno por vários dias e notei que o mesmo não aprenderia a ler por causa de sua deficiência, mas notei algo diferente nele nas aulas de dança. Comecei a questionar como ensina-lo a dançar em meio a tantas dificuldades. Juntamente com a professora de dança fomos pesquisar e planejar para ensinar esse aluno, fizemos adequação de conteúdo e descobrimos que ele deveria ser motivado e incluso nas aulas com os outros alunos, o resultado foi espetacular, trabalhamos a autoestima da criança, a coordenação do corpo, o ritmo da musica, ensinamos-lhe a ouvir diversos sons e até a dançar. Piaget diz que todo conhecimento provém de ações, por isso foi 
bastante gratificante para o aluno a inclusão dele no meio, sua interação passou a ser significativa. E nossos objetivos alcançados" (PROFESSOR D).

No caso dos bibliotecários, um explorou as etapas necessárias, mas sem muito aprofundar, sem demonstração dos desdobramentos das possíveis hipóteses. Outros dois demonstraram as etapas, levantaram as hipóteses e as analisaram com base em informações coletadas para tomar a decisão; um deles identificou a situação, procurou alternativa e solucionou o problema. Os quatro conseguiram traçar um plano, considerando o pensamento reflexivo. Em um dos casos, a solução demonstrada para o problema inicial não foi apresentada com clareza.

$\mathrm{Na}$ dimensão estética, a criatividade e o pensamento crítico são fundamentais, mas esses aspectos foram explorados de forma superficial pelos participantes. As atividades apresentaram o que era esperado, que ao se deparar com situação problema e tendo um roteiro a seguir, conseguissem tomar decisões a partir da intuição e de estoques prévios de conhecimento a respeito do assunto. $O$ fato de apenas dois estudantes buscarem informações para apoiar o processo decisório deixa claro que o comportamento geral é mais baseado na experiência, o que não deixa de ser válido, mas muitas vezes não é o caminho mais seguro. Para Gasque e Cunha (2010), as pessoas quase sempre agem de forma intuitiva por não possuírem conhecimento e competências para realizar as atividades demandadas no processo de busca, o que poderia ser minimizado caso houvesse o uso do pensamento reflexivo.

Como apontam Vitorino e Piantola (2011), a dimensão estética da competência expressa a experiência individual e única do sujeito ao lidar com os conteúdos de informação, sendo assim era de se esperar que cada estudante utilizasse a bagagem anterior para agir diante do contexto apresentado. Consideramos que os participantes do curso são capazes de utilizar o pensamento reflexivo, ainda que não de maneira aprofundada, para a solução de problemas cotidianos, porém falta buscar informações em outras fontes para fundamentar as decisões tomadas. 


\subsubsection{Dimensão ética}

A dimensão ética da competência em informação possui os seguintes aspectos:

- Uso responsável da informação.

- Realização do bem comum.

- Relação entre as questões de apropriação e uso da informação, tais como propriedade intelectual, direitos autorais, acesso à informação e preservação da memória do mundo.

A atividade selecionada para análise fora solicitada no módulo Ética da informação, no Eixo 4 - Dimensão Ética. Foi a última atividade realizada no módulo, no tópico em que se abordou o tema "plágio e autoria". Anteriormente foram trabalhados os temas: ética e sociedade da informação e liberdade de expressão: possibilidades e limites. A tarefa consistiu na elaboração de um conto que relacionasse os temas ética e propriedade intelectual, discutindo o plágio no âmbito acadêmico. Os trabalhos foram avaliados de acordo com a adequação do conteúdo ao tema proposto e ao que é exigido de um indivíduo que reconheça os princípios éticos para o uso da informação. As categorias definidas para análise foram: 1-ética no uso da informação; 2propriedade intelectual e direitos autorais.

$\mathrm{Na}$ análise do conteúdo das atividades, foi possível identificar que, em relação à ética no uso da informação, dois dos professores não compreenderam a proposta, pois apresentaram contos que não se relacionam aos propósitos solicitados, nem ao contexto acadêmico. Os outros dois utilizaram como pano de fundo o contexto acadêmico, demonstrando que é um assunto que deve ser discutido em sala de aula, talvez por ser prática recorrente entre os estudantes. Há um ponto que merece reflexão, em dois dos contos apresentados, os autores mencionam a falta de atenção e comprometimento dos professores com a correção minuciosa dos trabalhos apresentados pelos estudantes, responsabilizando-os também pelo fato de plagiarem trabalhos alheios, como é possível observar nos fragmentos a seguir: 
"Maria é uma menina que acabou de entrar na faculdade de pedagogia. Ela escolheu o curso pela afinidade e vocação.

Maria entedia de computador e tecnologia, estudava em uma sala lotada de uma Universidade pública.

Maria trabalhava e estudava e tinha tempo para redes sociais.

Os professores da universidade já no primeiro ano passavam muitas atividades: trabalho, resumo, resenha, fichamento e tudo Maria copiava.

Maria, Maria seus trabalhos copiava e nenhuma a referencia não colocava.

Porem os professores não reparava que Maria só copiava.

Primeiro ano passou Maria foi aprovada

Copiava e copiava..." (PROFESSOR E).

"E agora? O que vou fazer? Seu amigo Romário disse: Eu posso Ihe ajudar! Ela perguntou: Como? Romário respondeu dizendo que tinha um site na internet de confiança que podia pegar a resenha do livro inteiro. Miriam falou e se o professor pegar? Romário disse: Nada os professores nem lê estes trabalhos" (PROFESSOR F).

Nos fragmentos apresentados, observamos palavras sem acentuação, erros de concordância e coerência textual e também de digitação, o que demonstra problema encontrado em diversas atividades ao longo do curso: dificuldade em dominar a norma culta, o que nos faz questionar a formação desses profissionais. Em relação ao conteúdo, destaca-se a percepção que os estudantes têm com frequência a respeito dos professores, mas que nem sempre é verdadeira, a de que não são cuidadosos com as correções dos trabalhos acadêmicos. Interessante que os próprios professores reconhecem isso.

Há que se fazer uma pergunta, os docentes estão cientes dessa responsabilidade? Mais do que isso, estão aptos a perceber casos de plágio e violação de direito autoral? Conhecem as normas para citar e referenciar corretamente a autoria? São vários aspectos que merecem atenção e que deveriam permear a formação deles. Werthein (2000), aponta que um dos aspectos éticos da informação que devem ser discutidos na sociedade contemporânea, está relacionado aos direitos de propriedade intelectual, inclusive na internet em que o público e privado tem se confundido cotidianamente.

$\mathrm{Na}$ análise dos trabalhos realizados pelos bibliotecários, o aspecto comum aos quatro contos foi a relação com o contexto acadêmico. Há situações de cópia integral do trabalho de colegas, produção de textos científicos para os quais não houve a 
devida instrução a respeito das normas, e muitos questionamentos a respeito do papel do docente no processo, assim como foi identificado nos contos produzidos pelos professores. Em fragmento do conto produzido por um bibliotecário fica claro esse aspecto:

\begin{abstract}
"Ela começou a refletir como era estranho descobrir que desde as séries iniciais fazia parte da produção de seus trabalhos copiar, seja parcial ou totalmente, textos de outros, sem indicar a fonte dos documentos. O pior, pensava, era agora saber que os professores tinham esse conhecimento o tempo todo, mas o plágio era algo aceitável por parte deles. O conceito de plágio nem sequer era pincelado na mente dos alunos em seu tempo de escola, ela somente teve o contato com esse conceito agora na universidade durante as explicações do professor sobre esse assunto" (BIBLIOTECÁRIO G).
\end{abstract}

A discussão sobre o fato de a produção de textos desde o ensino básico ser prática pouco instruída pelo professor, sem levar em consideração a propriedade intelectual, o plágio e as normas é latente, e percebida no discurso dos participantes do curso. Isso nos leva a questionar que tipos de conteúdos existem na formação desses profissionais para ocorrer essa reflexão. Em contrapartida, em um dos contos apresentados, o professor é representado de maneira diferente, como preocupado e atento às questões que envolvem a propriedade intelectual, como pode-se observar no fragmento a seguir:

"O professor, após receber os arquivos da produção de cada discente, promete dar o retorno na aula seguinte. Chegado o dia da devoluta dos trabalhos o professor de Sociologia, cabisbaixo e indiferente à turma entra na sala, coloca sobre a mesa seus materiais e defronte ao quadro escreve:

- Palavras, palavras, palavras.

- O que as palavras dizem, senhor?

- Mentiras, senhor. O escritor descreve velhos e é muito grosseiro em relação a eles.

- Vocês sabem de quem são essas falas memoráveis?

- Sabemos, professor!

- Imaginei que soubessem, pois trabalhamos essa obra. E por que muitos de vocês não fizeram a devida citação deste fragmento no texto que me entregaram?

- Como assim, citação?

- Esse fragmento faz parte de uma peça teatral de William Shakespeare, um diálogo entre Hamlet e Polônio. Não é um texto de autoria de vocês. E isso deveria ter sido configurado no trabalho. Não o fazendo vocês cometem um crime de direito autoral, o plágio" (BIBLIOTECÁRIO H). 
Outro ponto que chama a atenção nas atividades dos bibliotecários é a ênfase dada às normas, todos mencionaram a importância de citar e referenciar corretamente. No quadro 8, é possível visualizar as categorias de análise e os respectivos termos mencionados nos contos produzidos pelos participantes.

\section{Quadro 8 - Análise da dimensão ética da competência em informação}

\begin{tabular}{|l|l|}
\hline \multicolumn{1}{|c|}{ CATEGORIAS } & \multicolumn{1}{|c|}{ POSICIONAMENTO DOS PARTICIPANTES } \\
\hline 1 - Ética no uso da informação & $\begin{array}{l}\text { Cópia; plágio; não referenciar; não citar; crime; moral; } \\
\text { professores não atentos; indicação da fonte; direitos } \\
\text { autorais; normas ABNT; produção do conhecimento } \\
\text { científico; }\end{array}$ \\
\hline $\begin{array}{l}\text { 2 - Propriedade intelectual e direitos } \\
\text { autorais }\end{array}$ & $\begin{array}{l}\text { Respeito aos direitos; autenticidade; apropriação; dar } \\
\text { crédito ao autor; penalidades; autoria. }\end{array}$ \\
\hline
\end{tabular}

Fonte: dados da pesquisa (2015).

A análise da atividade permite concluir que professores e bibliotecários percebem em situações cotidianas a importância de usar a informação de forma ética, respeitando os direitos do autor, fazendo uso das normas de citação e referência a fim de que não incorram em plágio. Na prática nem sempre há essa coerência, pois em outras atividades ocorreram casos de plágio diversas vezes, seja por falta de conhecimento ou má fé.

Para Krokoscz (2011, p.765) o plágio no meio acadêmico deve ser enfrentado a partir de esforços das instituições de ensino na adoção de políticas relacionadas ao assunto, tais como "adoção de Códigos de Ética, apresentação de conteúdo relacionado ao plágio nas home page das universidades brasileiras, integração do estudo sobre escrita acadêmica e plágio em matéria específica da grade dos cursos superiores". O autor destaca que no Brasil o tema é incipiente e tais medidas precisam ser empregadas para que a prática diminua.

Barbastefano e Souza (2007), em pesquisa realizada com estudantes de graduação, evidenciam que os mesmos entendem que desde que o autor seja referenciado, a obra pode ser copiada, o que é uma compreensão equivocada dos direitos autorais. A questão do uso de imagens é ainda mais grave, segundo a pesquisa 
os estudantes as utilizam devido à facilidade de encontrá-las na internet, não solicitando ao autor o direito de reprodução. A facilidade de acesso à informação na internet, desconhecimento das regras de citação e dificuldade para parafrasear, são alguns fatores apontados pelos autores como motivadores do plágio acadêmico. Medida proposta pelos autores é que se inclua a temática em disciplinas como Metodologia da Pesquisa.

O fato é que a ética no uso da informação precisa ser trabalhada em todos os níveis educacionais, a fim de que ao longo da trajetória acadêmica o estudante compreenda os motivos de não se apropriar da ideia de outrem. $O$ fato de as atividades de pesquisa desenvolvidas nos ensinos fundamental e médio serem pouco instruídas em relação às normas e a questões que envolvam o direito autoral, contribui para que na graduação o estudante tenha pouco, ou nenhum conhecimento sobre o assunto.

\subsubsection{Dimensão técnica}

A técnica geralmente está relacionada às habilidades para executar determinada atividade, e talvez por isso a dimensão técnica da competência seja a mais citada na literatura e também a mais pesquisada, visto que é mais fácil mensurar do que as demais (VITORINO; PIANTOLA, 2011). Está relacionada à capacidade de o indivíduo localizar as informações necessárias e saber avaliá-las, além de dominar as tecnologias da informação e interagir com as mesmas a fim de atender aos propósitos de busca e recuperação da informação. De acordo com as autoras supracitadas, essa dimensão pode ser resumida em:

- Meio de ação no contexto da informação.

- Habilidades adquiridas para encontrar, avaliar e usar a informação de que precisamos.

- Habilidades para o acesso e o domínio das novas tecnologias. 
Para avaliar a competência dos participantes do CELI no que diz respeito à dimensão técnica, foi selecionada atividade aplicada no módulo Busca pela Informação, inserido no Eixo 5 - Dimensão Técnica. A atividade solicitada envolveu cinco etapas, conforme orientações dos docentes responsáveis. O objetivo era identificar se o estudante consegue reconhecer a necessidade de informação, escolher a fonte mais adequada, aplicar os critérios de qualidade para fontes de informação, selecionar as estratégias de busca e avaliar os resultados obtidos.

A análise possibilitou perceber alguns aspectos. Dos quatro professores, três demonstraram ter domínio das etapas do processo de busca, e um deles apresentou visão superficial, não explorando corretamente cada etapa. É interessante observar dentre os que realizaram a tarefa com êxito, que ficou claro a definição de necessidade de informação, que é uma etapa determinante para o êxito da busca, visto que a partir dela, as outras ações se desencadeiam. Os critérios para a seleção da fonte de informação mais adequada para solucionar o problema também estavam claros. Em relação à seleção da estratégia de busca, alguns utilizaram busca simples no Google, outros pesquisa avançada e ainda há aqueles que buscaram em fontes de informação específicas da área a qual estava relacionada o problema de pesquisa, demonstrando conhecimento sobre algumas fontes de informação.

Diversos estudos sobre comportamento informacional apontam que reconhecer as próprias necessidades de informação não é tarefa fácil, e também não o suficiente para desencadear um processo de busca (CARVALHO, 2010; MIRANDA, 2006). É preciso que o indivíduo se sinta motivado a buscar informação para solucionar o problema, e para tanto necessita compreender todo o processo de busca. Os estudantes ao concluírem o processo demonstram que adquiriram conhecimentos sobre as etapas e conseguiram aplicá-los.

No caso dos bibliotecários, a análise é bastante semelhante, com a diferença no detalhamento utilizado para descrever cada etapa. Talvez por estarem mais familiarizados com a terminologia da área, em dois dos quatro trabalhos há explicações 
sobre as diferenças entre as fontes de informação, e em três atividades os critérios utilizados para a seleção da fonte foram mencionados e explicados.

Nos trabalhos dos professores e bibliotecários percebeu-se certa dificuldade em seguir as etapas do processo de busca à risca, sendo que a única que foi mencionada em primeiro em todas as tarefas foi a identificação da necessidade de informação, até porque disso dependia as outras fases. A aplicação dos critérios e definição das estratégias de busca foram as etapas que frequentemente se inverteram. Em alguns casos, os critérios foram aplicados após a definição da estratégia. Isso parece ter ocorrido porque a maior parte dos participantes utilizou o Google como fonte de informação. Então, era preciso primeiro ir ao Google, depois selecionar dentre os documentos recuperados aquele que atendia a necessidade, em seguida ir ao documento e aplicar os critérios para avaliar a fonte. Porém, mesmo com essa alteração no percurso, os resultados foram satisfatórios, pois no momento de avaliar se a informação obtida estava adequada aos propósitos da busca, todos avaliaram positivamente. Um deles reforçou que mesmo com resultado satisfatório, seria necessário realizar buscas em outras fontes para aprofundar o tema, o que demonstra atitude positiva em relação ao processo.

A dimensão técnica da competência foi a última a ser trabalhada no CELI, e esse foi um aspecto bastante positivo, visto que os estudantes tiveram acesso primeiramente aos conteúdos que permitiram visualizar a competência de forma mais abrangente, para assim ter maiores condições de refletir no momento de trabalhar a técnica. $\mathrm{Na}$ concepção teórica de Vitorino e Piantola (2011) sobre as dimensões, evidencia-se que a competência necessita das habilidades técnicas, mas para se concretizar precisa das outras três. Nessa atividade, foi possível perceber, que houve avanço considerável em relação à primeira atividade do curso, por ser aplicada no penúltimo módulo. Isso parece indicar que ao longo do processo de formação os estudantes foram incorporando os novos conhecimentos ao estoque inicial. 


\subsection{ANÁLISE DO PROJETO POLÍTICO PEDAGÓGICO DO CURSO E DO AMBIENTE VIRTUAL DE APRENDIZAGEM}

A análise do curso de especialização em Letramento Informacional tem como propósito a identificação de elementos fundamentais para a estruturação de cursos de formação continuada na modalidade EAD, bem como a proposição de diretrizes para tal formação. Como instrumento de coleta de dados utilizou-se o ambiente virtual de aprendizagem e o Projeto Político Pedagógico do curso (PPP).

O PPP do curso foi elaborado pelas docentes do curso de Biblioteconomia da UFG Suely Gomes, Andréa Santos e Janaina Fialho, e contou com a colaboração de outros seis professores e um bibliotecário, sendo cinco da UFG e dois da UNB. O curso teve a previsão de 400hs divididas em 18 meses, porém terminou em 15 meses devido a cortes no orçamento, iniciando em Agosto/2014 e encerrando as atividades em Dezembro/2015. Foram ofertadas 200 vagas distribuídas nos polos de Águas Lindas, Anápolis, Goianésia, Inhumas, Jussara e Uruaçu, cidades do interior do Estado de Goiás. Um dos requisitos para que o estudante participasse do processo seletivo era o de que fosse bibliotecário ou professor da rede pública, municipal ou estadual de educação básica.

Analisando o documento foi possível observar que se destaca a importância de qualificar os professores e bibliotecários do Estado de Goiás para educação voltada ao uso da informação nos aspectos éticos, técnicos, políticos, estéticos, baseando-se em Vitorino e Piantola (2011) e político-pedagógico, fundamentado em Campello (2006) e Gasque (2012).

Reconhece-se que falta formação adequada por parte dos professores e, também bibliotecários para que possam conduzir os estudantes nas pesquisas e auxiliar a cumprir o ciclo informacional nas etapas de seleção, análise, tratamento e uso da informação. 
O Curso de Especialização em Letramento Informacional: a educação para a informação visa preencher uma lacuna na formação de professores e bibliotecários para atuarem como promotores de Letramento Informacional na escola, visando a inclusão digital, a formação do aluno pesquisador, a melhoria do ensino e o uso ético da informação no meio acadêmico e profissional (PPP CELI, 2013).

Evidencia-se também que as práticas de sucesso de letramento informacional na escola, tem demonstrado que a parceria entre professores e bibliotecários é fundamental para a realização de um trabalho eficiente.

De um modo geral, reconhece-se que professores e bibliotecários são atores fundamentais na formação de pessoas letradas em informação e o que se constata é que os próprios agentes pedagógicos e de inclusão digital carecem, eles mesmos, de uma educação para a informação e precisam desenvolver suas competências e habilidades informacionais (PPP CELI, 2013).

No documento é apontado que a ausência do letramento informacional leva ao desvio ético no uso da informação, fazendo do plágio prática corriqueira no ambiente acadêmico e que precisa ser combatida. O curso então se dispõe a desenvolver competências em cada uma das dimensões citadas, como apontado a seguir:

a) Dimensão técnica: habilidades para localizar, organizar, dominar as regras de comunicação científica oral e escrita, conhecer e dominar o uso de ambientes virtuais para o compartilhamento e construção coletiva do conhecimento;

b) Dimensão estética: Capacidade de compreender, relacionar, ordenar, configurar atribuir significado à informação para a produção de novos conhecimentos;

c) Dimensão ética: Fazer e promover o uso ético e responsável da informação;

d) Dimensão política: compreender a informação como socialmente produzida em um determinado contexto político;

e) Dimensão político-pedagógica: Estruturar projetos e ações pedagógicos que contemplem estratégias e conteúdos para o desenvolvimento da competência em informação dos alunos, observadas as diferentes etapas/séries do ensino formal.

Baseando-se nessas dimensões, estruturou-se em torno dos seguintes objetivos:

a) Investir na formação continuada de educadores, principalmente professores da educação básica;

b) Contribuir para o aperfeiçoamento da competência em informação de alunos e de profissionais da educação, principalmente professores em exercício na Educação Básica; 
c) Discutir os aspectos históricos, teóricos e metodológicos do letramento informacional e contextualizá-lo na sociedade contemporânea e no processo de educação formal;

d) Discutir estratégias e fatores intervenientes para desenvolvimento e implantação de programas de letramento informacional na escola;

e) Apontar caminhos para articular o letramento informacional à prática docente e à proposta pedagógica da escola sob uma concepção interacionista de aprendizagem;

f) Propiciar o domínio de ferramentas, estratégias e técnicas para busca, organização, uso, comunicação e compartilhamento eficientes da informação.

De posse desses dados, partimos para a análise da estrutura do curso no ambiente virtual de aprendizagem moodle, sempre relacionado ao PPP. O acesso à plataforma de ensino foi permitido a partir de autorização da coordenação do curso para conduzir a pesquisa.

Após levantamento na literatura e percepções da pesquisadora devido à atuação como docente e tutora em cursos EAD, identificamos alguns elementos percebidos como fundamentais para estruturar cursos a distância com qualidade, sendo eles: estrutura curricular e pedagógica, docentes e tutores, material didático, estratégias de ensino, metodologias de avaliação e ambiente virtual de aprendizagem. O levantamento baseou-se nos apontamentos dos seguintes autores como demonstrado no quadro abaixo.

Quadro 9 - Elementos fundamentais para estruturação de cursos EAD

\begin{tabular}{|c|c|}
\hline AUTOR & RECURSOS MENCIONADOS \\
\hline MARTINS (2008) & $\begin{array}{l}\text { Formação de professores especialistas e tutores, estrutura e } \\
\text { funcionamento dos centros associados, material didático, } \\
\text { processo de avaliação da aprendizagem, metodologia de ensino. }\end{array}$ \\
\hline BELLONI (2002) & Conteúdos, estratégias de ensino inovadoras. \\
\hline AMARILLA FILHO (2011) & $\begin{array}{l}\text { Estudante, professor, ambiente virtual de aprendizagem, } \\
\text { metodologias de aprendizagem. }\end{array}$ \\
\hline
\end{tabular}

Fonte: elaboração própria (2016).

Nos próximos tópicos serão descritos os elementos que constituem o curso de EAD em letramento informacional, analisados a partir da literatura educacional e da experiência da pesquisadora. 


\section{Estrutura curricular e pedagógica}

O curso foi dividido em 6 eixos teóricos, e cada eixo contou com um ou mais módulos. O Eixo 1 - Dimensão teórico-conceitual contemplou os módulos: Sociedade da Informação, Competência em informação e Letramento Informacional. O eixo teve carga horária de 60hs. O Eixo 2 - Dimensão estética contou com os módulos: Teoria sobre aquisição e desenvolvimento da linguagem e Pensamento reflexivo e produção do conhecimento, totalizando também $60 \mathrm{hs}$. O Eixo 3 - Dimensão político-pedagógico contemplou os módulos: Programas de letramento informacional na escola e Currículo escolar, totalizando 70hs. O Eixo 4 - Dimensão ética teve apenas um módulo: Ética da informação que contou com 30hs. O Eixo 5 - Dimensão técnica foi o mais extenso, contemplando os módulos: Comunicação científica, Ambientes colaborativos, Normalização do trabalho acadêmico, Busca pela informação e Organização da informação, ambos totalizaram 140hs. O Eixo 6 - Metodológico contemplou os módulos Metodologia da Pesquisa e Oficina de Pesquisa, este último conduzido pelo orientador e seus respectivos orientandos do trabalho final do curso, totalizando $40 \mathrm{hs}$.

A divisão em eixos temáticos visa o desenvolvimento de competências específicas do educando, o que para o processo formativo é bastante enriquecedor. Martins (2008) sinaliza que a concepção mais adequada para trabalhar a formação de professores em EAD é a orientação para o desenvolvimento de competências. Nesse sentido, o CELI demonstra por meio do PPP que o curso foi planejado em função das competências que se pretendia desenvolver, por isso adotou a proposta de Vitorino e Piantola (2011) que abrange as dimensões da competência em informação.

Pesquisa realizada por Mata e Casarin (2012) indica que há carência na formação dos bibliotecários de disciplinas relacionadas à educação e abordagem pedagógica, visto que são necessárias para atuação no contexto escolar. Sendo assim, o curso de formação continuada em Letramento Informacional deve preencher essa lacuna abordando tal conteúdo. No CELI, duas disciplinas especificamente abordaram 
conteúdos relacionados ao tema no eixo denominado Político-Pedagógico, sendo elas: Programas de Letramento Informacional na Escola e Currículo Escolar.

\section{Equipe}

Trabalhar com projetos de EAD requer amplo conhecimento e discussão sobre a finalidade formativa e as bases das práticas pedagógicas (MARTINS, 2008). Isso exige capacitação das equipes envolvidas. Sobre a equipe pedagógica, o PPP do curso destaca que:

Fica claro para a equipe pedagógica que a garantia da observância dos princípios e métodos pedagógicos aqui traçados exigirá dela uma atuação coletiva, intensa, contínua, integrada e integralizadora tanto para operacionalização da grade curricular quanto para a organização dos materiais e as definições das situações problemas que conduzirão o processo de ensinoaprendizagem, dando um encadeamento natural e lógico ao sequenciamento dos conteúdos (PPP CELI, 2003).

O curso contou com a seguinte estrutura pedagógica: 19 professores autores, responsáveis pela produção de conteúdos para o curso; 28 tutores à distância, dos quais 9 são também professores autores, responsáveis por mediar os debates e conduzir as discussões dos estudantes na plataforma de ensino e 6 tutores presenciais, que tiveram como tarefa atender às demandas dos estudantes nos polos de apoio presencial. Para atuar em cada um dos módulos, foram designados um professor responsável e um participante. Dessa forma, havia duas salas, cada qual conduzida por um docente.

A produção do conteúdo de cada módulo era responsabilidade do docente conteudista, que deveria produzir o material textual. O material consistiu em um capítulo sobre o tema, elaboração das atividades avaliativas, e determinação das estratégias utilizadas. Além dessas atribuições, o professor na EAD deve se portar como "animador, criador de possibilidades de aprendizagem" (AMARILLA FILHO, 2011, p.50), pois o processo de construção do conhecimento pelo estudante não é linear e se enquadra em outra configuração espaço-temporal. 
As funções do tutor diferem das do docente, pois estão mais relacionadas à interação direta com o estudante. O objetivo é acompanhá-lo no processo de ensinoaprendizagem, promovendo a interação necessária entre professores e estudantes e entre os próprios estudantes, conforme aponta o PPP do curso.

Uma característica interessante do curso foi a de que a maior parte dos tutores foram os docentes que elaboraram os conteúdos, o que possibilitou ganho para os estudantes, visto que partimos do pressuposto de que aquele que desenvolve o conteúdo está mais apto a discutir sobre o assunto. Além disso, para capacitar tutores que, muitas vezes, não tem conhecimento da temática trabalhada, requer trabalho cuidadoso para que a mediação e a relação com os estudantes não seja prejudicada.

De maneira geral, a quantidade de docentes por módulo, a forma como a tutoria fora constituída, e a produção do conteúdo pelos docentes participantes, são aspectos positivos do curso e podem servir como direcionamento para outros cursos de formação continuada em Letramento Informacional a distância. Por outro lado, a condução dos conteúdos pelos docentes se assemelha muito à metodologia adotada no ensino presencial, reproduzindo o mesmo modelo. É preciso pensar em materiais didáticos e estratégias de ensino diferenciadas para o ensino a distância a fim de obter êxito no curso.

\section{Material Didático e estratégias e ensino}

O material didático e as estratégias de ensino são dois pontos fundamentais da $E A D$ apontados por quase todos os autores pesquisados. É fundamental que não seja transposto o modelo presencial para o ambiente virtual, como se apenas a tecnologia fizesse a diferença. As análises permitem identificar que apesar de no PPP do curso estar previsto reunião entre os docentes e a equipe de produção dos materiais a fim de alinhar o formato e apresentação do texto, ao verificar cada um dos capítulos produzidos evidencia-se que há diferenças. Não houve linguagem padrão e alguns materiais foram meramente textuais enquanto outros mais didáticos, contando com 
exemplos. Houve produção de vídeo em alguns módulos e, em outros, não. Os materiais didáticos do curso foram todos eletrônicos, o único impresso foi o guia do estudante.

Foi possível perceber ao acessar a plataforma, que o uso de recursos audiovisuais ou autoinstrucionais foram limitados. A metodologia de ensino adotada foi, principalmente, o uso de sensibilização, visando o contato inicial do estudante com a temática, podendo ser um vídeo, tirinha ou outro material que despertasse o interesse, leitura de texto base do módulo e também textos complementares, participação nos fóruns de discussão, sendo esses avaliativos ou não, e realização de tarefa ao final de cada conteúdo trabalhado. Como a maioria dos módulos foi de 3 semanas, a estratégia utilizada foi a mesma descrita acima para cada semana. Tal metodologia pode ser considerada enriquecedora, pois busca trabalhar diversos tipos de materiais, porém não é inovadora e ainda muito centrada em textos e na figura do professor que permeia o debate. A interação entre os estudantes no fórum foi sempre positiva, visto que permite que tenham outro olhar sobre $\mathrm{o}$ assunto discutido. Os objetos educacionais de aprendizagem utilizados em EAD devem ser desenvolvidos baseando-se na interatividade do estudante com o conteúdo. Para tanto, requer planejamento e elaboração criteriosa, principalmente no modelo centrado no discente, e não no docente como geralmente é o ensino presencial (ROZADOS, 2009, p.49). Tal produção demanda tempo, planejamento e equipes capacitadas.

Uma possibilidade de diversificação dos materiais seria utilizar objetos educacionais disponíveis em repositórios, que de acordo com o conteúdo poderiam atender aos propósitos do curso. Exemplo disso é o Banco Internacional de Objetos Educacionais disponibilizado pelo $\mathrm{MEC}$, que oferece inúmeros materiais digitais que podem ser utilizados para apoiar o ensino de diversas áreas. A Ciência da Informação conta com sete objetos na plataforma, que é diversificada pelos níveis de ensino, como observa-se na figura a seguir. 
Figura 8 - Banco Internacional de Objetos Educacionais

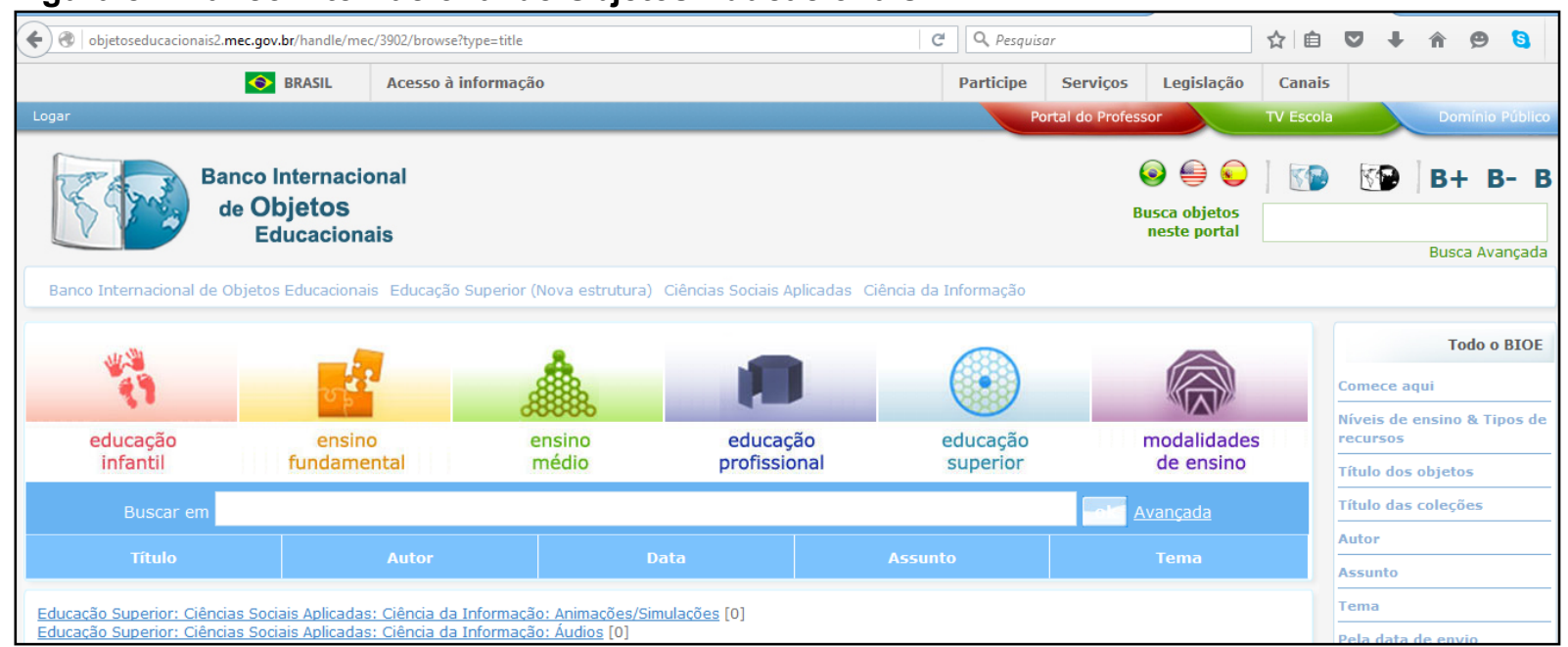

Fonte: http://objetoseducacionais2. $\mathrm{mec}$. gov.br/handle/mec/3902/browse?type=title

O uso de objetos de aprendizagem é facilitado pelo fato de poder ser reutilizado, por isso a inserção em repositórios. É uma perspectiva que congrega com os interesses da sociedade da aprendizagem, pois visa o compartilhamento.

Outras estratégias de ensino utilizadas no curso foram os encontros presenciais, divididos em videoconferências (6), jornada de integração para apresentação do curso (1), prova (1), oficina de projeto final (1) e seminário para a defesa final de projeto (1), o que contribui para a aproximação dos estudantes entre si e com os professores. $O$ fato de haver fóruns de discussão nos módulos e, ainda, fórum para tirar dúvidas dos estudantes sobre assuntos diversos relacionados ao curso e não aos conteúdos, demonstra a importância da interação nos cursos EAD, pois possibilita maior aproximação e motivação para o estudante.

No curso a distância é fundamental que o estudante dedique algumas horas por dia para estudo do material e execução das atividades propostas, além de participar nos fóruns e tirar possíveis dúvidas. Se não houver disciplina, facilmente se perde e se desmotiva para dar continuidade aos estudos. No CELI, havia recomendação que os estudantes se dedicassem pelo menos durante $2 \mathrm{hs}$ diária para estudo e realização das atividades. O tempo tem sido um problema constante para a EAD, como aponta Belloni (2002), visto que não há previsão de quantitativo de horas para se dedicar à formação 
continuada dentro da jornada de trabalho dos professores, o que torna o aprendizado pouco aprofundado. Além disso, o estudante precisa compreender que é o próprio construtor do conhecimento, ou seja, é preciso ter autonomia e disciplina (AMARILLA FILHO, 2011). A autonomia, como aponta Zuin (2006), é o mote da EAD atual, sendo assim os cursos estão cada vez mais voltados em possibilitar aprendizagem autônoma.

Sobre a seleção dos conteúdos a serem ministrados nos cursos $E A D$, é preciso priorizar a reflexão, análise crítica e a produção de conhecimentos, como aponta Martins (2008). A autora reforça que:

Esta seleção deve assegurar certos princípios epistemológicos, metodológicos,
curriculares e deve evitar as armadilhas de cópias dos trechos de outros
autores, ou da montagem de apostilas e textos que nada mais fazem do que
ressuscitar posturas tradicionais já abolidas na aula presencial. Os conteúdos
devem ser apresentados de forma questionadora e ou de enigmas e conter
sempre uma visão problematizadora (MARTINS, 2008, p.364).

Em suma, percebemos que de acordo com as atividades propostas em cada eixo temático, bem como os materiais didáticos desenvolvidos, os estudantes tiveram o contato com os conteúdos fundamentais do letramento informacional. Porém, para o desenvolvimento da competência propriamente dita é preciso que atividades práticas sejam planejadas, a fim de permitir que possa refletir e aplicar os conhecimentos adquiridos.

\begin{abstract}
AVA
Os Ambientes Virtuais de Aprendizagem (AVA) constituem-se como plataformas interativas de ensino, que dependem das TICs para funcionar. Tem função fundamental na EAD por permitir maior interação do estudante com os conteúdos e com os demais agentes envolvidos, tais como docentes, tutores, estudantes e o material didático. Nas palavras de Amarilla Filho (2001, p.48), "o que dá sentido à Educação a Distância não é a dicotomia espacial e temporal, mas, ao contrário, sua capacidade de diminuir tal separação", o que é permitido e permeado pela tecnologia, por meio dos AVA. Ainda, para o autor, é preciso escolher ambientes que "privilegiem não apenas a exposição de
\end{abstract}


conteúdos, mas também a interação e a colaboração coletivas no processo de ensinoaprendizagem" (AMARILLA FILHO, 2011, p.51).

O AVA utilizado no curso foi o moodle, plataforma utilizada em praticamente todos os cursos EAD ofertados por instituições públicas por ser gratuito. O ambiente possui diversos recursos que possibilitam a interação entre os estudantes e também, entre estes e os docentes e tutores, como fórum e chat. Além disso, serve como repositório dos materiais didáticos, das disciplinas e permite que os estudantes postem as atividades, ficando assim com o registro da trajetória acadêmica e notas. $\mathrm{O}$ ambiente permite que cada disciplina tenha sala, e cada professor também, sendo assim a administração dos conteúdos ministrados torna-se prática.

Quando o ambiente não se restringe a mero repositório de documentos, mas a promover maior interação entre os envolvidos, passa a cumprir o verdadeiro propósito, que é o de propiciar aprendizagem mais significativa. Neste sentido, o moodle mostrouse adequado para os propósitos de curso.

Desse modo, a análise de todos os critérios identificados como fundamentais para cursos de LI em EAD, foram assim condensadas no quadro a seguir.

Quadro 10 - Análise do CELI em relação aos critérios para cursos EAD

\begin{tabular}{|c|c|}
\hline Critérios & CELI \\
\hline $\begin{array}{l}\text { Estrutura curricular e } \\
\text { pedagógica }\end{array}$ & $\begin{array}{l}\text { Divisão em eixos temáticos, orientada para o desenvolvimento de } \\
\text { competências. }\end{array}$ \\
\hline Equipe & $\begin{array}{l}\text { Maior parte dos tutores foram os docentes que elaboraram os } \\
\text { conteúdos. } \\
\text { Quantidade de docentes por módulo, a forma como a tutoria fora } \\
\text { constituída, e a produção do conteúdo pelos docentes } \\
\text { participantes, são aspectos positivos do curso e podem servir } \\
\text { como direcionamento para outros cursos de formação continuada } \\
\text { em Letramento Informacional a distância. }\end{array}$ \\
\hline $\begin{array}{l}\text { Material didático e } \\
\text { estratégias de ensino }\end{array}$ & $\begin{array}{l}\text { A condução dos conteúdos pelos docentes se assemelha muito à } \\
\text { metodologia adotada no ensino presencial, reproduzindo o } \\
\text { mesmo modelo. } \\
\text { É preciso pensar em materiais didáticos e estratégias de ensino } \\
\text { diferenciadas para o ensino a distância a fim de obter êxito no } \\
\text { curso. }\end{array}$ \\
\hline AVA & $\begin{array}{l}\text { Quando o ambiente não se restringe a mero repositório de } \\
\text { documentos, mas a promover maior interação entre os }\end{array}$ \\
\hline
\end{tabular}




\begin{tabular}{|l|l|}
\hline & $\begin{array}{l}\text { envolvidos, passa a cumprir o verdadeiro propósito, que é o de } \\
\text { propiciar aprendizagem mais significativa. Neste sentido, o } \\
\text { moodle mostrou-se adequado para os propósitos de curso. }\end{array}$ \\
\hline
\end{tabular}

Fonte: elaboração própria (2016).

\subsubsection{Diretrizes para a formação continuada em letramento informacional na modalidade EAD}

As especificidades da educação a distância, demonstradas ao longo da tese, demandam atenção de alguns aspectos específicos, tais como a infraestrutura tecnológica, equipes pedagógicas qualificadas, produção de material didático adequado e metodologias de avaliação pertinentes ao conteúdo. Esses elementos estando em consonância com o projeto político pedagógico do curso, bem como os objetivos propostos, tendem a garantir a qualidade do mesmo.

No cenário atual da educação, está claro que a educação por meio de novas mídias conectadas é uma realidade cada vez mais presente e que evolui de forma irreversível; além disso, devido ao processo de inclusão escolar, é fundamental a formação continuada do professor, visto que muitos, que hoje exercem a docência, não tiveram esses conteúdos e práticas durante sua formação (RODRIGUES; CAPELLINI, 2012, p.618).

A formação continuada de professores e bibliotecários para o letramento informacional na modalidade EAD, deve trabalhar conteúdos que desenvolvam a capacidade do indivíduo refletir e tomar decisões em relação à informação. Deveria constituir-se como disciplina, ensinada desde a educação básica até o ensino superior, mas, como os currículos não contemplam a temática, é preciso valer-se de outras estratégias. Tal formação tem como propósito atender aos déficits na formação inicial dos profissionais que lidam com a informação, a fim de capacitá-los nos processos que envolvem a busca, seleção, uso e consequente transformação da informação em conhecimento. Nessa perspectiva, passa a ser interessante para professores e bibliotecários, buscar tal capacitação para que estejam aptos a trabalhar os conceitos de LI na escola, tornando-se multiplicadores desse conhecimento junto aos estudantes. 
Sabe-se que a EAD tem sido pouco utilizada como estratégia de formação continuada em LI, como demonstra levantamento realizado no capítulo 6 , porém o potencial de alcance é enorme, visto que não impõe os limites espaciais e físicos do ensino tradicional. Para trabalhar os conteúdos do LI são necessárias metodologias adequadas, tanto para desenvolvimento de material didático, quanto de estratégias de ensino e avaliação. Como a intenção é promover a visão crítica a respeito do universo informacional, e também a aplicação prática dos conhecimentos adquiridos, há que se pensar em tarefas que permitam a ação dos estudantes participantes em contextos reais de aplicação de tal conhecimento.

Madeira (2006) aponta que em EAD é preciso utilizar diversos meios e recursos no processo de ensino-aprendizagem a fim de minimizar a distância física entre professores e estudantes. A capacitação do corpo docente deve ser a primeira etapa no planejamento do curso, pois possibilita alinhar as estratégias de ensino, discutir sobre questões metodológicas e produção do material didático. Alguns docentes não estão familiarizados com a dinâmica, relação espaço-tempo e interação com o estudante nos ambientes virtuais de aprendizagem, o que acaba prejudicando o aprendizado.

A produção do material didático deve ser pensada de modo que possibilite ao estudante interagir com ele, utilizando de animações, vídeos e não apenas textos. Dentre as estratégias de ensino adotadas, a web conferência deve ser considerada, visto que permite ao estudante dirimir possíveis dúvidas e interagir com os docentes de forma mais dinâmica. Encontros presenciais também favorecem a interação e podem reforçar as relações dos estudantes entre si.

Os referenciais de qualidade em EAD propostos pelo MEC (2007) indicam que é fundamental para o sucesso de um curso a distância, o comprometimento com a formação não apenas técnica do educando, mas também política. Isso deve ser descrito no projeto político pedagógico do curso e nortear as ações e direções tomadas no decorrer da sua realização. 


\subsection{AVALIAÇÃO DO CELI PELOS PARTICIPANTES}

A avaliação do CELI pelos participantes foi dividida em 6 blocos, os quais também foram utilizados na análise do PPP: estrutura pedagógica do curso, docentes, material didático e estratégias de ensino, metodologias de avaliação, tutoria e ambiente virtual de aprendizagem. As questões foram baseadas em avaliações dentro de escala do tipo Likert que variou de 1 - péssimo a 6 - excelente.

Obteve-se o retorno de 34 questionários, o que corresponde a $35 \%$ dos estudantes do curso. Havia 95 ativos durante o período de aplicação da pesquisa. Para facilitar as análises, apresentamos os aspectos descritivos dos dados de cada bloco separadamente. Ao final de cada, foram feitos as análises críticas.

\subsubsection{Bloco 1- Estrutura pedagógica do curso}

No bloco 1 buscou-se avaliar a estrutura pedagógica do curso. A primeira questão diz respeito à divisão do curso em eixos. Dos respondentes, $48,5 \%$ consideram muito bom e $39,4 \%$ excelente. Como a maior parte das avaliações se concentrou nos níveis 5 e 6 , a avaliação desse item é positiva.

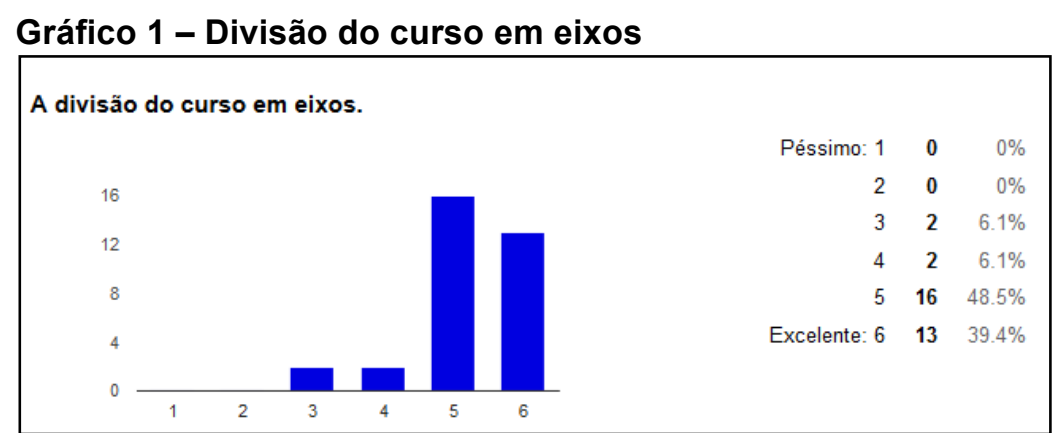

Fonte: dados da pesquisa (2015).

O segundo item avaliado foi a concepção pedagógica do curso em dimensões. Entre os pesquisados, 48,5\% consideram excelente e $36,4 \%$ muito bom. Tendo em vista que a maior parte das avaliações se concentrou nos níveis 5 e 6 , a avaliação desse item foi positiva. 
Gráfico 2 - Concepção pedagógica em dimensões

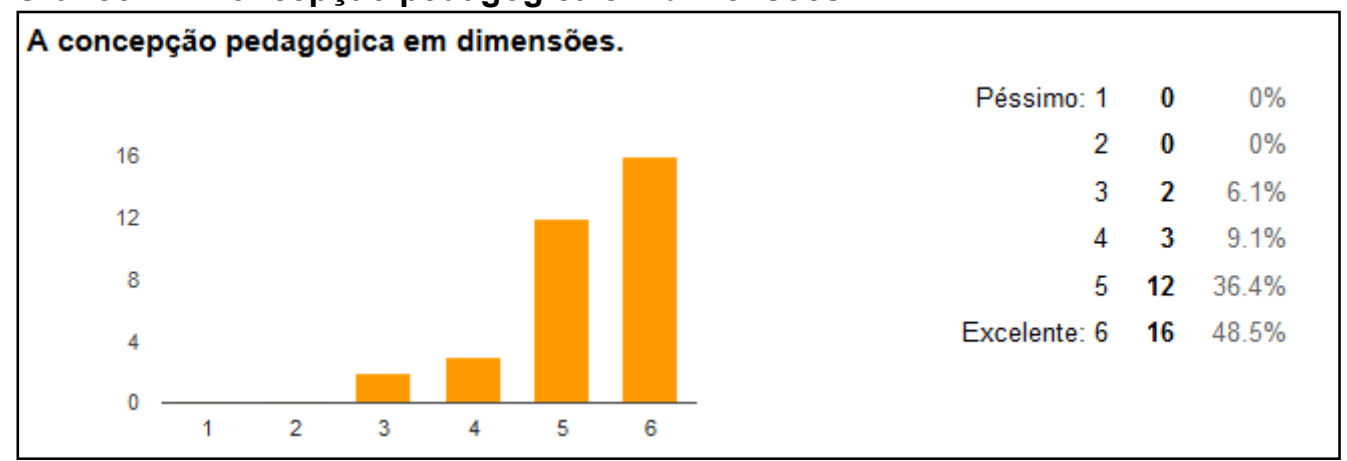

Fonte: dados da pesquisa (2015).

O terceiro item avaliado foi o conteúdo trabalhado no Eixo 1 - teórico conceitual. A maior parte das respostas concentrou-se nos itens excelente com $43,8 \%$ e muito bom $31,3 \%$, o que demonstra também avaliação positiva.

Gráfico 3 - Conteúdo trabalhado no eixo 1

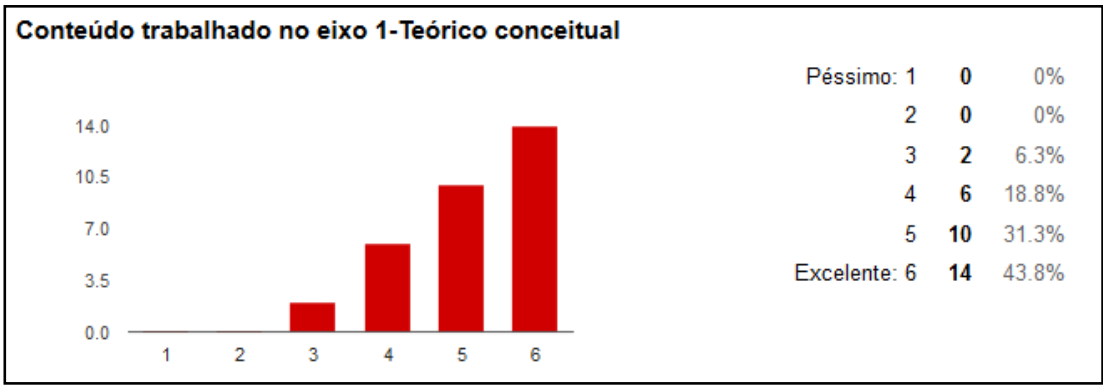

Fonte: dados da pesquisa (2015).

O quarto item avaliado foi o conteúdo trabalhado no Eixo 2 - dimensão estética, no qual foi possível identificar que os estudantes consideraram o conteúdo excelente $48,5 \%$, e muito bom $24,2 \%$, concentrando então $72,7 \%$ das respostas como positivas. No gráfico 4 é possível visualizar as respostas.

\section{Gráfico 4 - Conteúdo trabalhado no eixo 2}

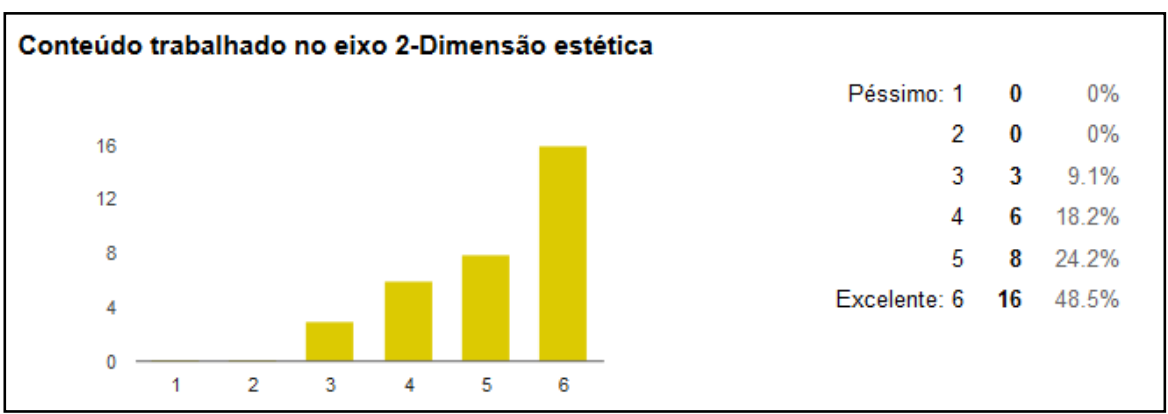

Fonte: dados da pesquisa (2015). 
O quinto item avaliado no bloco 1 foi o conteúdo trabalhado no Eixo 3 dimensão político pedagógica. Foi considerado pelos estudantes excelente $51,5 \%$ e muito bom $30,3 \%$, o que demonstra que a maioria das avaliações é positiva.

\section{Gráfico 5 - Conteúdo trabalhado no eixo 3}

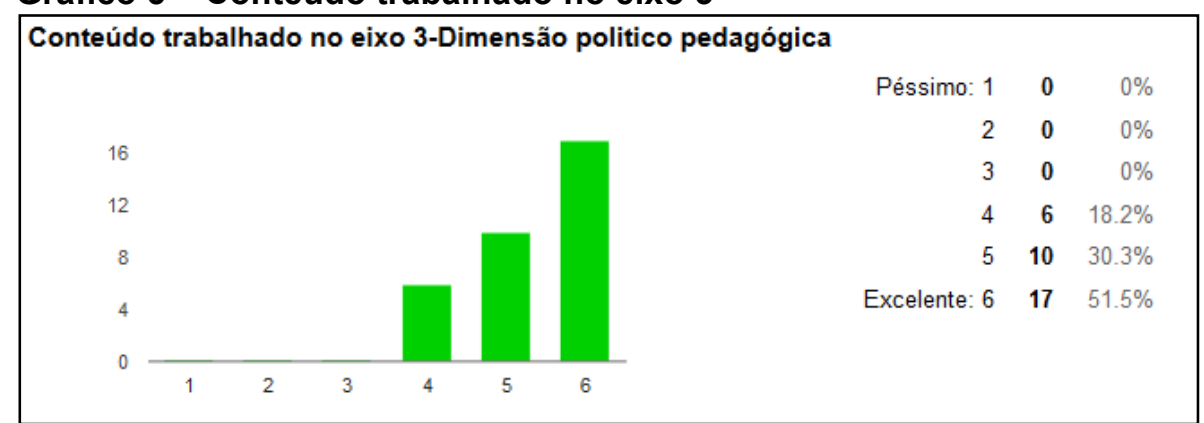

Fonte: dados da pesquisa (2015).

O sexto item avaliado no bloco 1 foi o conteúdo trabalhado no Eixo 4 - dimensão ética, o qual foi considerado pelos estudantes excelente $51,5 \%$ e muito bom $33,3 \%$. Isso demonstra que a maioria das avaliações quanto ao conteúdo desse eixo é positiva.

\section{Gráfico 6 - Conteúdo trabalhado no eixo 4}

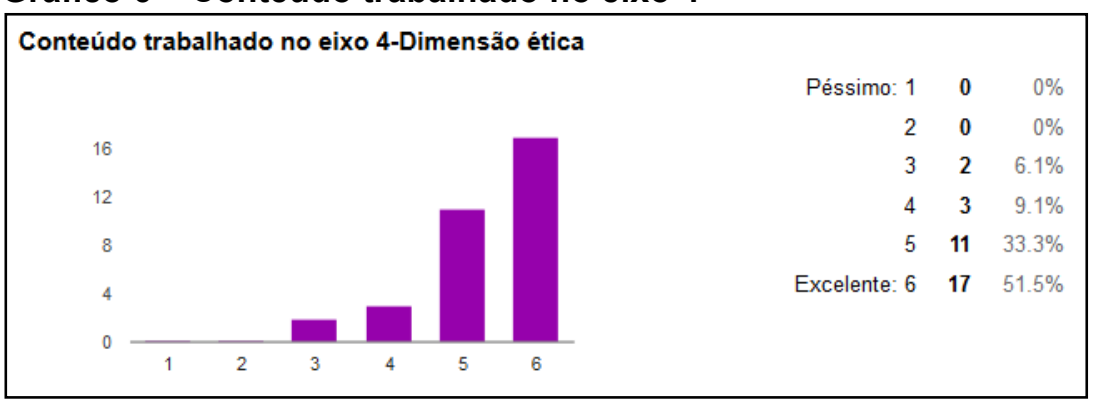

Fonte: dados da pesquisa (2015).

O sétimo item avaliado no bloco 1 foi o conteúdo trabalhado no Eixo 5 dimensão técnica. Foi considerado pelos estudantes excelente $42,4 \%$ e muito bom $33,3 \%$, o que demonstra que a maioria das avaliações quanto ao conteúdo desse eixo também é positiva. 
Gráfico 7 - Conteúdo trabalhado no eixo 5

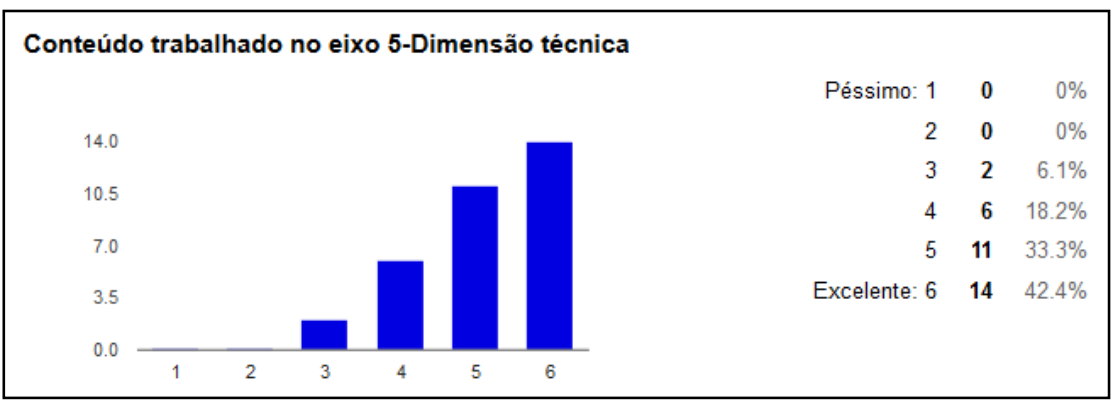

Fonte: dados da pesquisa (2015).

O oitavo item avaliado no bloco 1 foi o conteúdo trabalhado no Eixo 6 metodológico, que foi considerado pelos estudantes excelente $48,5 \%$ e muito bom $33,3 \%$. O resultado demonstra que a maioria das avaliações desse eixo também foi positiva, como podemos observar no gráfico 8.

Gráfico 8 - conteúdo trabalhado no eixo 6

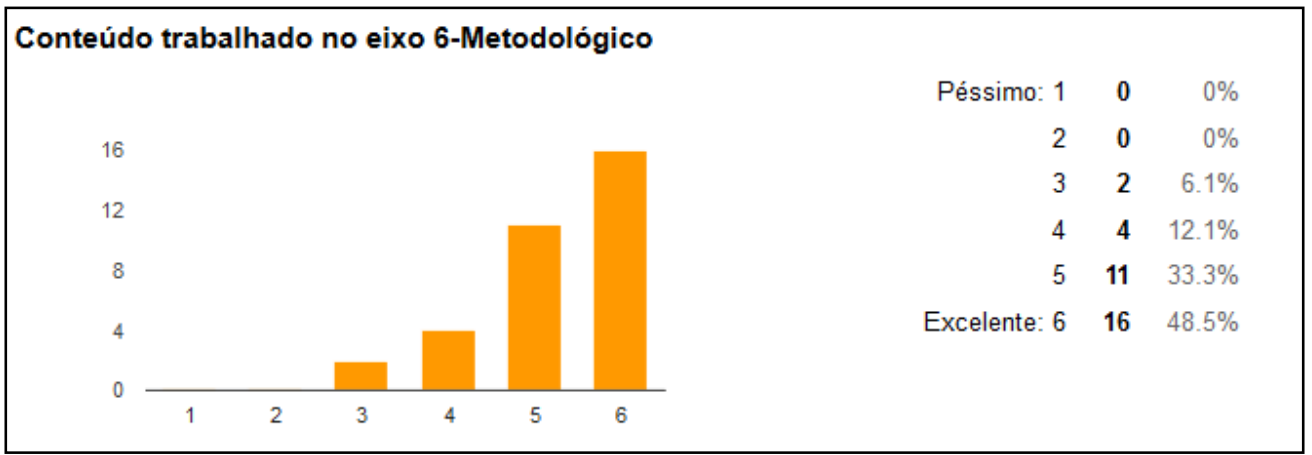

Fonte: dados da pesquisa (2015).

No campo aberto destinado a comentários sobre a estrutura pedagógica do curso, doze estudantes emitiram a opinião. Elas foram condensadas na tabela a seguir.

Tabela 4 - Pontos destacados pelos estudantes no bloco 1

Pontos destacados Participantes

\begin{tabular}{ll}
\hline Estrutura pedagógica & 6 \\
Material didático & 2 \\
Professores & 3 \\
Disciplinas & 4 \\
\hline
\end{tabular}

Fonte: dados da pesquisa (2015). 
Os estudantes mencionaram pontos que versavam principalmente sobre os tópicos: estrutura pedagógica, material didático, professores e disciplinas. No que diz respeito à estrutura, foi evidenciado que houve promoção de aprendizado mais significativo devido ao modo como foi estruturado, a divisão em eixos temáticos. Sobre o material didático foi destacado a qualidade e a diversificação das atividades. Em relação aos docentes, alguns mencionaram que estes eram distantes dos estudantes, não davam feedback satisfatório, mas houve quem elogiasse a atuação. Vale destacar que há um bloco de questões exclusivamente sobre os docentes, portanto os estudantes acabaram emitindo opinião sobre vários assuntos sem atentar para isso. A respeito dos módulos, houve crítica específica ao de Comunicação Científica.

Como há as particularidades de cada módulo que não foram contempladas no questionário, pois não era objetivo do trabalho, alguns estudantes se posicionaram especificamente em relação a alguns itens. Podemos perceber isso pelas falas dos estudantes A, B e C:

"Muitos alunos (inclusive eu) tiveram dificuldades e queixas sobre o conteúdo ministrado na disciplina de Comunicação Científica pertencente ao Eixo 5 Dimensão técnica. Essas dificuldades se mostraram presentes na realização das atividades a distância e também na prova presencial" (ESTUDANTE A).

"O curso era voltado a professores e bibliotecários, porém algumas atividades lidavam com o cotidiano dentro de sala de aula, espaço que nem todos os bibliotecários tem domínio" (ESTUDANTE B).

"Atualmente no exercício de uma prática docente no contexto da Educação Infantil tenho vivenciado ações significativas e pedagógica com possibilidades do exercício da cooperação, do respeito e da autonomia que se efetiva em diálogos entre as crianças contribuindo para apropriação e ressignificação da cultura educacional reafirmada em vários momentos nesta especialização. Senti falta de uma contextualização para esta primeira etapa da Educação Básica. Mas, acredito que estamos em processo de ampliação teórico-conceitual do Letramento Informacional nas unidades educacionais" (ESTUDANTE C).

Em síntese, é possível perceber que em relação à estrutura pedagógica do curso, as avaliações de todos os itens foram positivas. A decisão de trabalhar em eixos temáticos, de acordo com o tipo de competência que se pretendia desenvolver, possibilitou ao estudante aprendizado mais significativo, como eles próprios mencionaram. Em relação à queixa de um dos estudantes a respeito da adequação do 
conteúdo das atividades à atuação do bibliotecário, a intenção de trabalhar exemplos e temáticas da educação deve-se à necessidade de promover o desenvolvimento de competências nessa área, porém, a forma como tal conteúdo foi abordado, pode não ter sido eficiente. Da mesma forma, há que questionar se a atuação do docente na biblioteca foi trabalhada do mesmo modo que a atuação pedagógica do bibliotecário na escola, pois são igualmente importantes apesar das particularidades de ambas.

\subsubsection{Bloco 2 - Docentes}

O bloco 2 buscou avaliar os docentes do curso nos seguintes itens: capacitação para condução das disciplinas; participação nos fóruns de discussão; disposição para auxiliar o estudante em suas dúvidas; relacionamento interpessoal com o estudante; condução das orientações do artigo final e quantidade de docentes por módulo.

No primeiro item foi possível verificar que a maior parte dos estudantes considera que a capacitação dos docentes é excelente com 39,4\%; em seguida muito bom com $36,4 \%$. Isso demonstra avaliação positiva, de acordo com o gráfico 9 , a seguir.

\section{Gráfico 9 - Capacitação docente para condução das disciplinas}

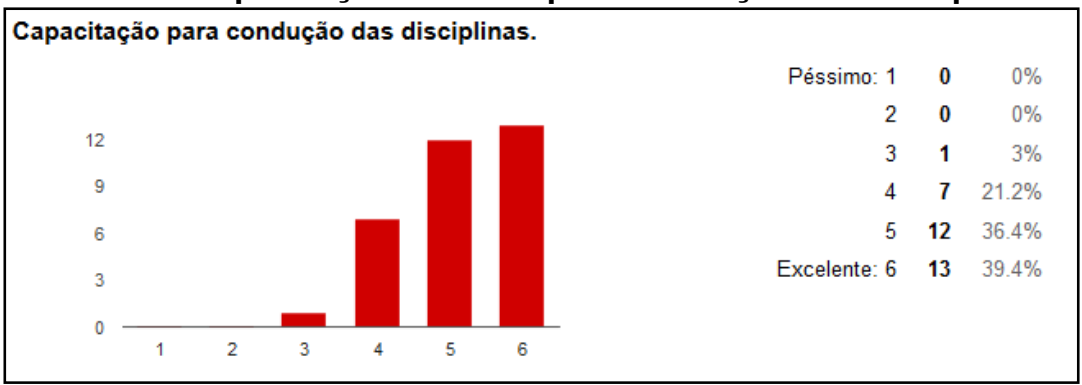

Fonte: dados da pesquisa (2015).

O segundo item avaliou a participação dos docentes nos fóruns de discussão realizados nas disciplinas. Constata-se que a maioria dos estudantes considera que foi muito boa com 42,4\%; em seguida avaliam como boa com $21,2 \%$ e excelente $18,2 \%$. Mesmo que a maior parte das respostas concentre-se nas avaliações 5 e 6 , houve parcela dos estudantes não satisfeita nesse quesito, o que é um aspecto que pode melhorar. 
Gráfico 10 - Participação docente nos fóruns de discussão

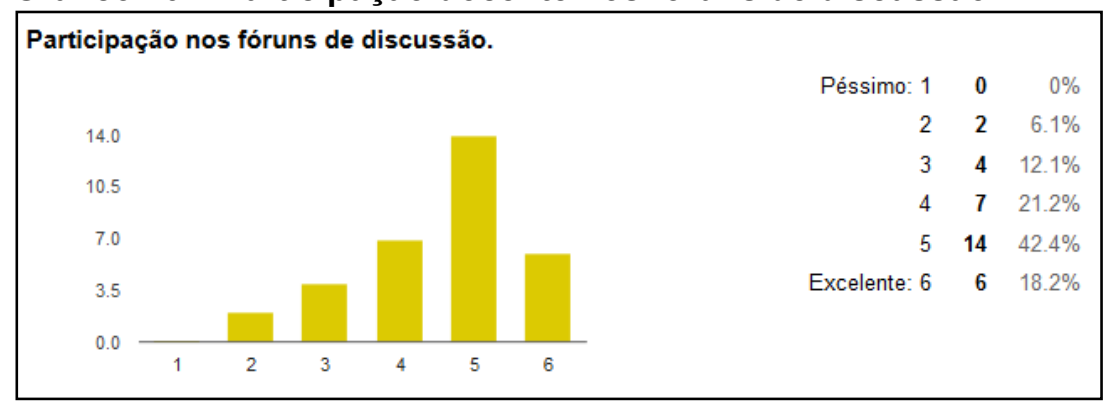

Fonte: dados da pesquisa (2015).

O terceiro item avaliado refere-se à disposição dos docentes para auxiliar os estudantes nas dúvidas no decorrer das disciplinas. Essa foi uma questão com opiniões diversas. Dos respondentes, 39,4\% consideram muito bom; $21,2 \%$ bom; aparecem empatados com $18,2 \%$ os níveis excelente e regular. Ainda que a maior parte das respostas $(57,6 \%)$ concentre-se nos níveis 5 e 6 , há $39,4 \%$ nos níveis 3 e 4 , que representam avaliação regular. Para se buscar excelência é preciso atentar a esses dados.

\section{Gráfico 11 - Disposição do docente para auxiliar o estudante em suas dúvidas}

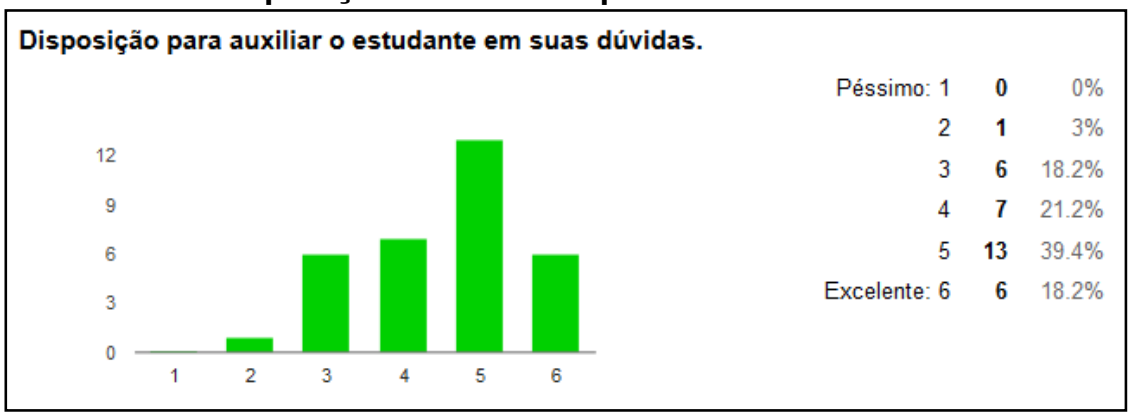

Fonte: dados da pesquisa (2015).

O terceiro item avaliou o relacionamento interpessoal dos docentes com os estudantes. Percebe-se que a $30,3 \%$ dos estudantes considerou bom. Em seguida avaliam como muito bom $27,3 \%$ e excelente $24,2 \%$. Outros $15,2 \%$ consideraram regular e $3 \%$ ruim. Nessa questão, a avaliação considerada positiva e a regular tiveram diferença de apenas $6 \%$, o que demonstra embate de opiniões. 
Gráfico 12 - Relacionamento interpessoal com o estudante

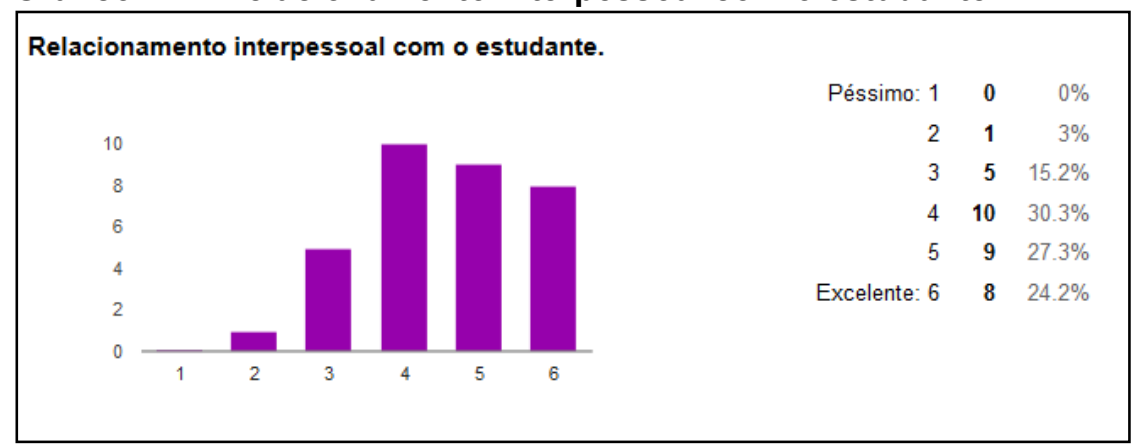

Fonte: dados da pesquisa (2015).

O quarto item avaliou a condução das orientações do artigo final do curso. As respostas demonstram que os estudantes ficaram satisfeitos com os orientadores e a forma como o processo foi conduzido, visto que $63,6 \%$ consideraram excelente e $15,2 \%$ muito bom. Importante destacar que $6,1 \%$ avaliaram como péssimo, o que não havia ocorrido com nenhum dos outros itens desse bloco.

\section{Gráfico 13 - Condução das orientações do artigo final}

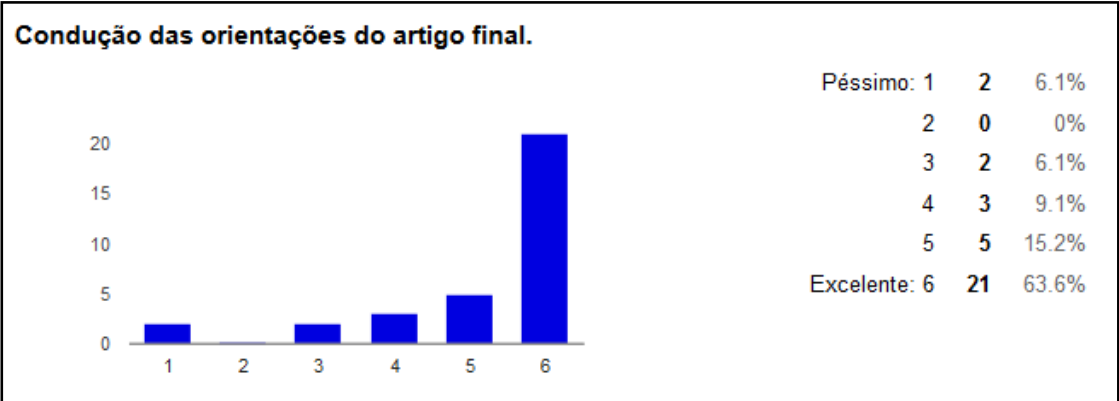

Fonte: dados da pesquisa (2015).

O quinto e último item avaliou a quantidade de docentes por módulo, que na maior parte do curso foi de dois. As respostas demonstram que os estudantes ficaram satisfeitos com o quantitativo, visto que $36,4 \%$ consideraram excelente e $33,3 \%$ muito bom. A avaliação desse item foi considerada positiva. 
Gráfico 14 - Quantidade de docentes por módulo

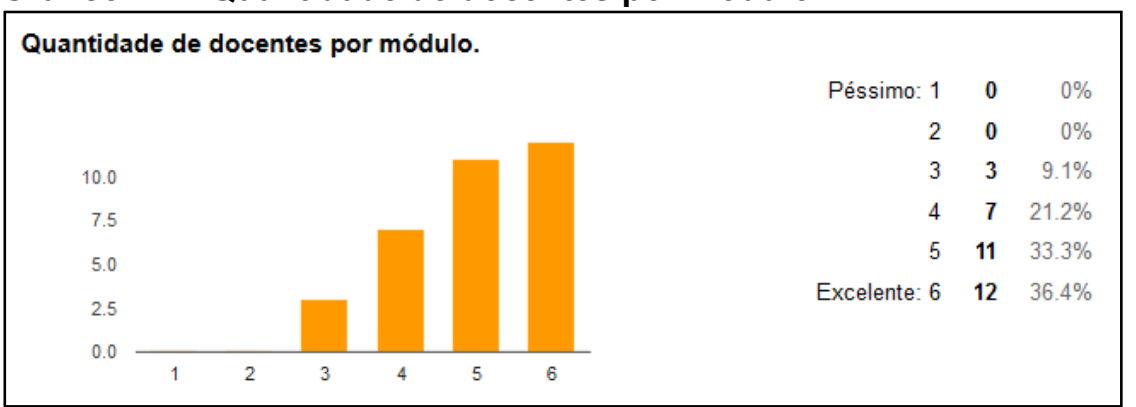

Fonte: dados da pesquisa (2015).

No campo aberto destinado a comentários sobre os docentes do curso, onze estudantes emitiram opinião, as quais foram agrupadas em dois blocos: críticas e elogios. Foi possível identificar sete elogios e cinco críticas à atuação docente, como é possível observar no quadro a seguir.

Quadro 11 - Críticas e elogios à atuação dos docentes

\begin{tabular}{|c|c|}
\hline Elogios & Críticas \\
\hline Excelentes profissionais & $\begin{array}{l}\text { Alguns se destacaram mais quanto à } \\
\text { participação nos fóruns e no auxílio aos } \\
\text { estudantes do que outros }\end{array}$ \\
\hline Professores muito bons & $\begin{array}{l}\text { Pouca intervenção nos fóruns, estudantes } \\
\text { sentiram-se abandonados }\end{array}$ \\
\hline Ensino tranquilo e agradável & Não deram retorno nos fóruns \\
\hline Boa assistência na condução dos módulos & $\begin{array}{l}\text { Problema na disciplina de Comunicação } \\
\text { Científica }\end{array}$ \\
\hline Destaque para a orientação final & Alguns deixaram a desejar \\
\hline \multicolumn{2}{|l|}{ Mediadores da aprendizagem } \\
\hline Formidáveis, todos inteirados do conteúdo & \\
\hline
\end{tabular}

Fonte: dados da pesquisa (2015).

As críticas feitas pelos estudantes vão ao encontro dos gráficos que avaliam a participação dos docentes nos fóruns, disposição para auxiliar os estudantes e relacionamento interpessoal, visto que nestes três quesitos houve pequena diferença entre a avaliação positiva e a regular. Percebe-se que houve insatisfação com alguns professores quanto à condução dos debates nos fóruns e assim como no bloco anterior, foi evidenciado problema na disciplina de comunicação científica. 
Sabe-se que em um curso a distância a interação entre docentes e estudantes é fundamental para o sucesso do aprendizado. Sobre esse aspecto Almeida (2003) argumenta que:

Quando o professor não se envolve nas interações com os alunos, o que é muito frequente, cabe ao tutor fazê-lo. Porém, caso esse tutor não compreenda a concepção do curso ou não tenha sido devidamente preparado para orientar o aluno, corre-se o risco de um atendimento inadequado que pode levar o aluno a abandonar a única possibilidade de interação com o tutor, passando a trabalhar sozinho sem ter com quem dialogar a respeito de suas dificuldades ou elaborações (ALMEIDA, 2003, p.330).

A fala do estudante " $D$ " reforça a importância do envolvimento do docente em uma especialização à distância.

"O programa teve professores de uma capacidade de informação, ética, moral, didatismo, indiscutível, entretanto alguns docentes ficaram a desejar. As relações interpessoais fazem a diferença em uma Especialização deste nível" (ESTUDANTE D).

Em resumo, esse bloco atestou que mesmo que a avaliação de todos os itens tenha sido considerada positiva, há pequena diferença para o regular, e os aspectos que precisam ser melhorados estão relacionados ao relacionamento interpessoal com os estudantes, e não aos conhecimentos e capacidade didática dos docentes, tanto que na condução do artigo final a maioria considerou a atuação excelente. Essa relação pode ter sido prejudicada pelo fato de que cada docente tem uma forma de trabalhar e de disponibilizar tempo para atender às demandas dos estudantes, e a EAD requer dinâmica diferente da sala de aula presencial, a qual nem todos estão habituados. É preciso investir em capacitação docente para trabalhar as especificidades da EAD e assim promover estratégias de ensino mais adequadas a essa realidade.

\subsubsection{Bloco 3 - Material didático e estratégias de ensino}

O bloco 3 teve como propósito avaliar o material didático desenvolvido e utilizado no curso, bem como as estratégias de ensino adotadas. Em quase todas as disciplinas, a metodologia consistia na disponibilização de um capítulo produzido por professores 
do curso, alguns vídeos, fóruns de discussão (avaliativos ou não), e atividades avaliativas. Essa estrutura foi avaliada pelos estudantes.

O primeiro item do bloco avaliou o conteúdo dos capítulos produzidos para cada eixo temático. A maioria dos estudantes 45,5\% considera excelente e 39,4\% consideram muito bom. A maior parte das respostas se concentra nos níveis 5 e 6 $(84,9 \%)$, o que representa que a avaliação desse item é positiva, como observa-se no gráfico 15.

Gráfico 15 - Conteúdo dos capítulos de cada eixo temático

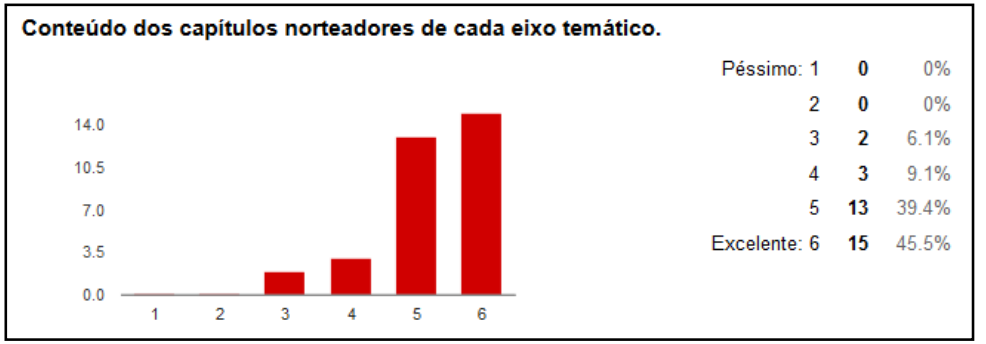

Fonte: dados da pesquisa (2015).

O segundo item avaliou a atualidade e criatividade dos conteúdos trabalhados nos módulos. Dos respondentes, $51,5 \%$ dos estudantes consideram excelente e $30,3 \%$ muito bom, o que demonstra que nesse item a avaliação foi considerada positiva. $O$ gráfico 16 permite visualizar as respostas.

\section{Gráfico 16 - Atualidade e criatividade dos conteúdos}

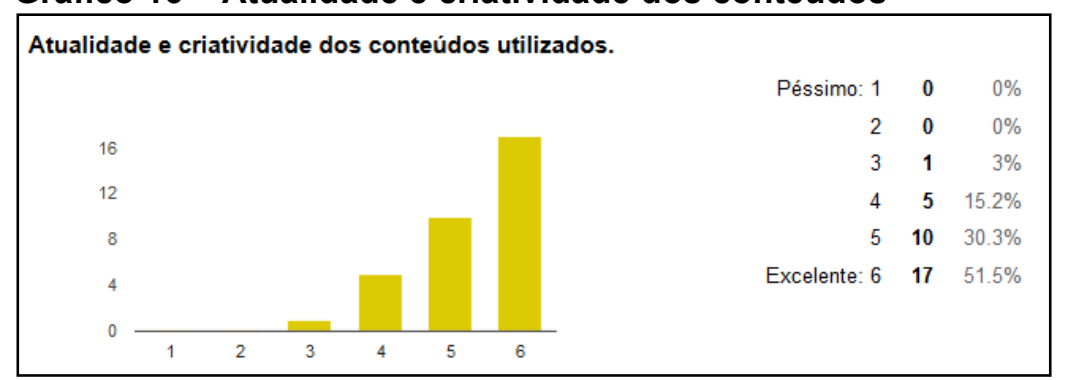

Fonte: dados da pesquisa (2015).

O terceiro item avaliou a diversificação das mídias utilizadas. Os resultados mostram que $43,8 \%$ dos estudantes consideram excelente e $21,9 \%$ muito bom. Percebe-se que a maior parte das avaliações foi considerada positiva para esse item. $O$ gráfico 17 permite visualizar as respostas. 
Gráfico 17 - Diversificação das mídias utilizadas

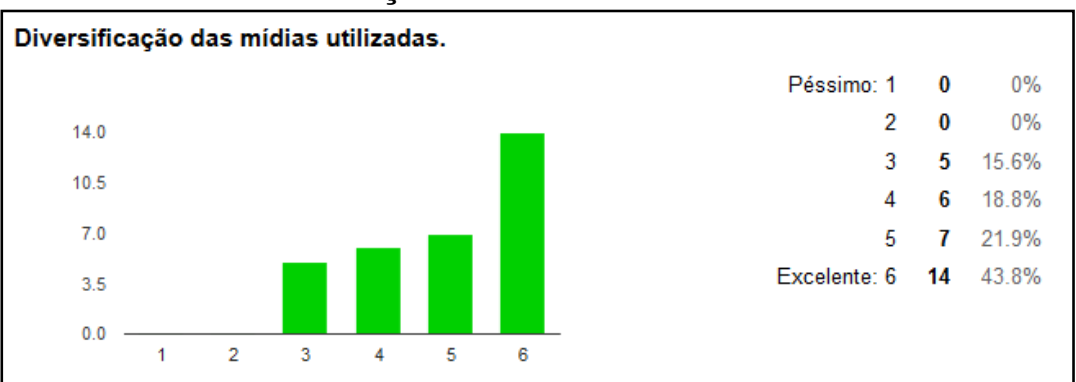

Fonte: dados da pesquisa (2015).

O quarto item do bloco avaliou se a quantidade de web conferências foi satisfatória. Nesse quesito fica evidente a insatisfação dos estudantes, visto que a maioria das respostas, $36,4 \%$ considera regular e $24,2 \%$ bom. A maioria das respostas $(60,6 \%)$ concentra-se nos níveis 3 e 4 , considerado como regular, como pode-se verificar no gráfico 18.

Gráfico 18 - Quantidade de web conferências

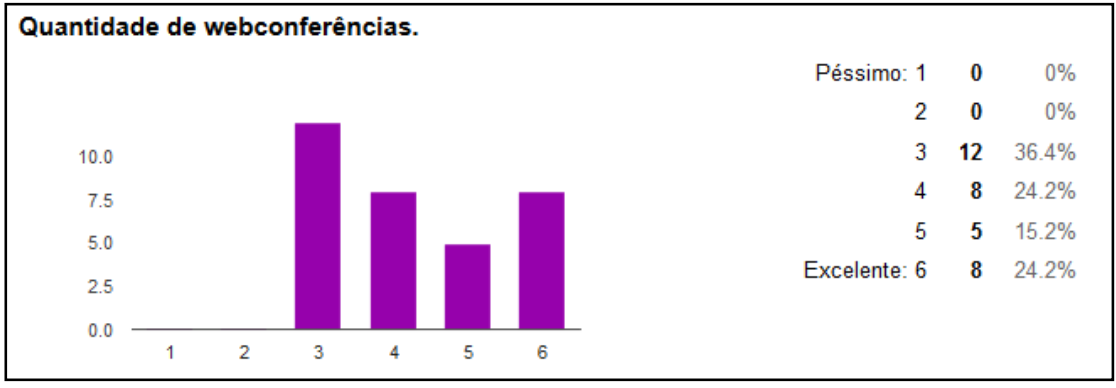

Fonte: dados da pesquisa (2015).

O quinto item avaliou se a estratégia de ensino: disponibilizar o material didático, promover discussão no fórum e, em seguida, realizar a tarefa solicitada, foi eficiente. Entre os respondentes, $45,5 \%$ dos estudantes consideram a estratégia muito boa e $33,3 \%$ excelente, indicando que nesse item a avaliação foi considerada positiva, e que a estratégia de ensino adotada cumpriu o seu propósito. O gráfico 19 permite visualizar as respostas. 
Gráfico 19 - Estratégia de ensino adotada

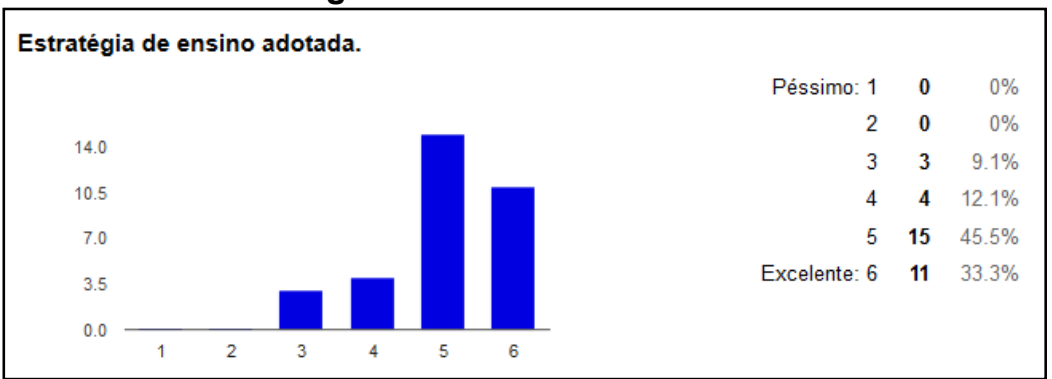

Fonte: dados da pesquisa (2015).

No campo aberto, destinado a comentários sobre o material didático e as estratégias de ensino, onze estudantes emitiram a opinião. Elas foram agrupadas, como podemos visualizar na tabela 6 .

Tabela 5 - Comentários acerca do material didático

\begin{tabular}{|l|l|}
\hline \multicolumn{1}{|c|}{ Pontos destacados } & \multicolumn{1}{c|}{ Quantitativo } \\
\hline Material didático & 7 \\
\hline Web conferência & 3 \\
\hline Estratégias de ensino & 4 \\
\hline
\end{tabular}

Fonte: dados da pesquisa (2015).

Foram sete avaliações para o material didático, que recebeu apenas elogios, sendo considerado proveitoso, excelente, perfeito, muito bom, ótimo, objetivo, apresentou o conteúdo de forma fácil. Um estudante ressaltou que o livro Letramento Informacional, da professora Kelley Gasque, como muito bom. O outro item que mais foi mencionado foram as web conferências. Os estudantes sugeriram que fossem realizadas ao final de cada disciplina ou quinzenais para sanar dúvidas, apontando como estratégia importante para auxiliar o aprendizado. Em relação às estratégias de ensino, os estudantes mencionaram que poderiam ter sido utilizadas mídias fora do moodle, consideraram as atividades inovadoras e desafiadoras e condizentes com o conteúdo. Um sugeriu que fossem utilizados mais vídeos, pois estes ajudam na compreensão dos conteúdos. A fala de "E" resume bem as opiniões dos estudantes. 
As opiniões emitidas nos comentários ratificam os dados obtidos por meio das questões avaliativas, visto que na questão sobre diversificação das mídias boa parte dos estudantes considerou regular. Nos comentários, há demonstração de que outras mídias poderiam ter sido utilizadas, o que pode servir como sugestão para nova edição do curso. Outro ponto que ficou em déficit foram as web conferências. O gráfico demonstra que esse item foi avaliado como regular, e isso é reforçado na fala dos estudantes que gostariam que as mesmas ocorressem mais vezes ao longo do curso, o que também pode ser visto como sugestão de melhoria.

Outro ponto relevante é pensar no perfil dos dois profissionais - professores e bibliotecários -, que participaram do curso, visto que possuem formações distintas e, consequentemente, níveis de conhecimento diferentes. Isso possivelmente demanda discussão mais profunda do corpo docente a respeito das estratégias e metodologias de ensino.

\subsubsection{Bloco 4 - Metodologias de avaliação}

O bloco 4 teve como propósito avaliar as metodologias de avaliação utilizadas no curso. Apesar de no PPP constar um padrão, cada professor poderia propor a atividade avaliativa que considerasse mais pertinente para aferir a apreensão do conteúdo por parte dos estudantes.

O primeiro item do bloco avaliou a pertinência das atividades em relação ao conteúdo ministrado. Há $39,4 \%$ dos estudantes que consideram muito bom e $30,3 \%$ excelente. A maior parte das respostas se concentra nos níveis 5 e $6(69,7 \%)$, o que representa que a avaliação desse item é positiva, como observa-se no gráfico 20. 
Gráfico 20 - Pertinência das atividades em relação ao conteúdo ministrado

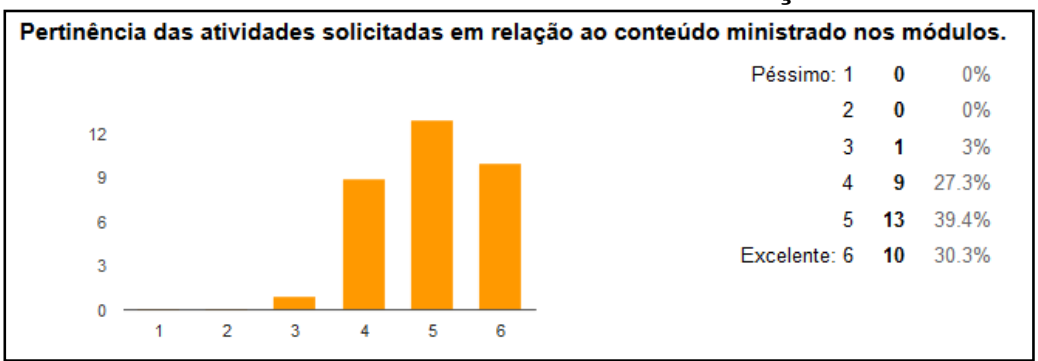

Fonte: dados da pesquisa (2015).

O segundo item do bloco avaliou a diversificação das atividades avaliativas, e as respostas obtidas demonstram que $36,4 \%$ consideram excelente e $33,3 \%$ muito bom; $18,2 \%$ avaliam como bom e $12,1 \%$ como regular. Apesar de nesse item a maior parte das respostas se concentrar nos níveis 5 e 6 (69,7\%), o que representa que a avaliação é positiva, há $30,3 \%$ que consideram regular, o se traduz em número relevante para se pensar em melhorias. O gráfico 21 permite a visualização das respostas de forma mais clara.

Gráfico 21 - Diversificação das atividades avaliativas

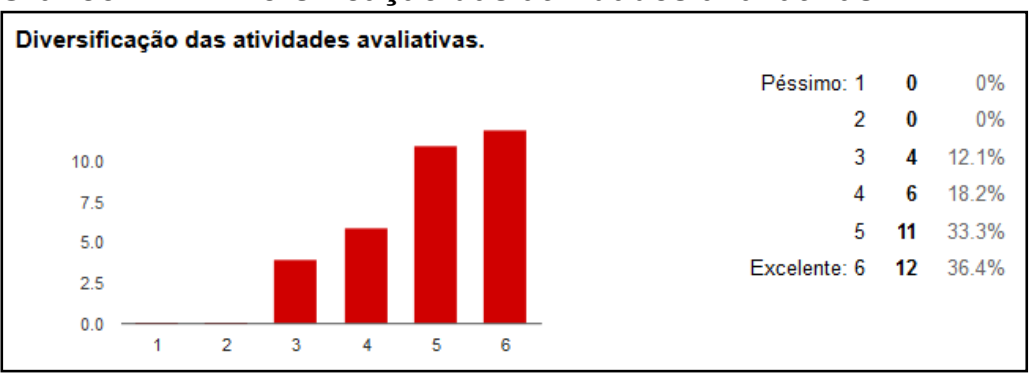

Fonte: dados da pesquisa (2015).

O terceiro item do bloco avaliou se as atividades avaliativas exploram a capacidade de reflexão dos estudantes. As respostas obtidas demonstram que 48,5\% consideram excelente e $33,3 \%$ muito bom. Nesse item, a maior parte das respostas se concentrou nos níveis 5 e 6 totalizando $81,8 \%$, o que representa que a avaliação é bastante positiva. O gráfico 22 permite a visualização das respostas de forma mais clara. 
Gráfico 22 - Atividades que exploram a capacidade de reflexão

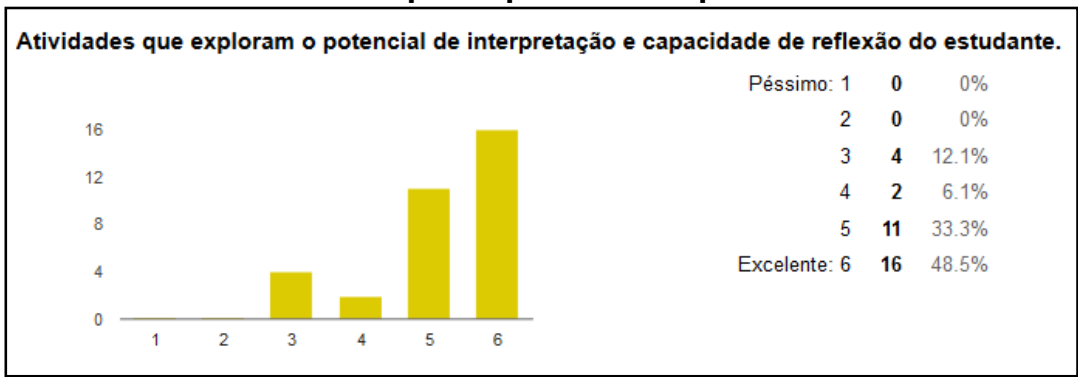

Fonte: dados da pesquisa (2015).

No campo aberto, destinado a comentários sobre as metodologias de avaliação, oito estudantes emitiram a opinião. Elas foram agrupadas, como podemos visualizar, na tabela 7.

Quadro 12 - Comentários dos estudantes sobre as Metodologias de avaliação

\begin{tabular}{|l|l|}
\hline \multicolumn{1}{|c|}{ Elogios } & \multicolumn{1}{c|}{ Críticas } \\
\hline Ampla e esclarecedora & Confusa na disciplina de Comunicação científica \\
\hline Boa & $\begin{array}{l}\text { Rever algumas atividades de acordo com o público-alvo } \\
\text { do curso }\end{array}$ \\
\hline Diversificadas & \\
\hline Variadas & \\
\hline Significativas & \\
\hline Excelente & \\
\hline Muito boa de & \\
\hline $\begin{array}{l}\text { Exploram o conhecimento do porém valioso } \\
\text { mundo }\end{array}$ & \\
\hline Desafio árduo porate & \\
\hline
\end{tabular}

Fonte: dados da pesquisa (2015).

Dentre as respostas dos participantes, foi perceptível que os mesmos ficaram satisfeitos com as metodologias de avaliação utilizadas no curso. Os elogios destacaram que as atividades foram diversificadas e variadas. Isso indica aspecto positivo para o curso, visto que demonstra envolvimento e criatividade por parte dos docentes. As críticas apresentadas foram novamente em relação à disciplina de comunicação científica, e ao fato de o público-alvo do curso ser composto por professores e bibliotecários, e algumas atividades demandaram conhecimentos que o bibliotecário não possuía. A questão do perfil do estudante volta à tona neste bloco, reforçando que é um aspecto a ser observado. 
As falas de alguns estudantes demonstram preocupação em propor melhorias, como o que é dito por "G":

"Rever algumas atividades, pois em algumas tive que elaborar plano de aula, coisa que não tenho vivência na minha profissão. O curso não era voltado somente para professores, mas para bibliotecários também!" (ESTUDANTE G).

Já a fala de "H" aponta para um ponto bastante interessante:

"Pensar reflexivamente é uma tarefa que exige esforço e em alguns momentos o desafio foi árduo, porém, valioso!" (ESTUDANTE H).

Os comentários reforçam os dados obtidos por meio do questionário, e são relevantes para a avaliação e proposta de melhorias para o curso. A diversificação das atividades foi considerada regular por $30 \%$ dos estudantes, indicando a necessidade de propor tarefas diferenciadas. Para tanto, seria necessário identificar que tipo de atividade avaliativa foi mais recorrente e tentar diversificá-las.

\subsubsection{Bloco 5 - Tutoria}

O bloco 5 avaliou a tutoria oferecida no curso. Havia dois tipos de tutor: o presencial, que deveria estar à disposição nos polos para atender eventuais demandas dos estudantes; e o tutor à distância, que fazia a mediação nos fóruns de discussão (quando não há docente) e fornecia assistência aos estudantes. Nem todos os polos de apoio presencial tiveram tutor, como alguns estudantes mencionaram.

O primeiro item do bloco avaliou o nível de conhecimento dos tutores a distância acerca dos assuntos abordados nas disciplinas. A maioria dos estudantes, 42,4\% considera esse aspecto excelente e $33,3 \%$ muito bom. Outras $75,7 \%$ das respostas concentram-se nos níveis 5 e 6 da escala, o que representa que a avaliação desse item é positiva, como observa-se no gráfico 23 . 
Gráfico 23 - Nível de conhecimento dos tutores à distância

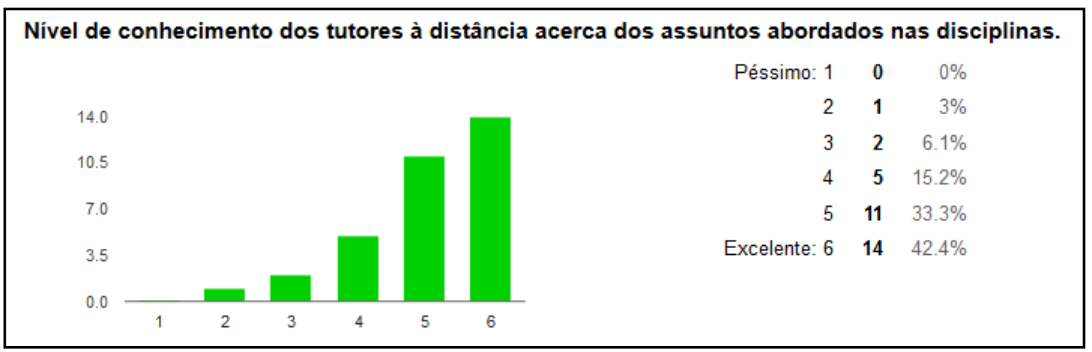

Fonte: dados da pesquisa (2015).

O segundo item avaliou a interação dos tutores à distância com os estudantes nos fóruns de discussão. Os níveis excelente e bom tiveram o mesmo percentual, com $33,3 \%$ cada. Outros $21,2 \%$ consideram muito bom. Apesar da avaliação desse item ser considerada positiva, a diferença para regular é pequena.

\section{Gráfico 24 - Interação dos tutores com os estudantes nos fóruns}

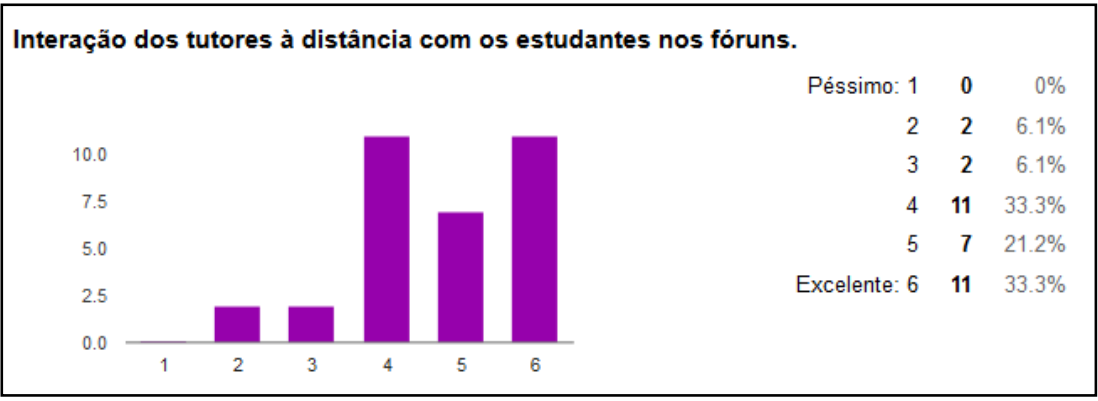

Fonte: dados da pesquisa (2015).

O terceiro item avaliou o feedback dado pelos tutores aos estudantes em cada módulo do curso. Os respondentes, 36,4\% consideram muito bom; 27,3\% excelente; $15,2 \%$ acham razoável; 12,1\% bom e 9,1\% ruim. Esse item apresentou respostas bem diversificadas. Percebe-se que apesar de 63,7\% das avaliações serem positivas, 27,3\% avaliam como regular, e há ainda $9,1 \%$ que avaliam como negativa. 
Gráfico 25 - Feedback das atividades desenvolvidas nos módulos

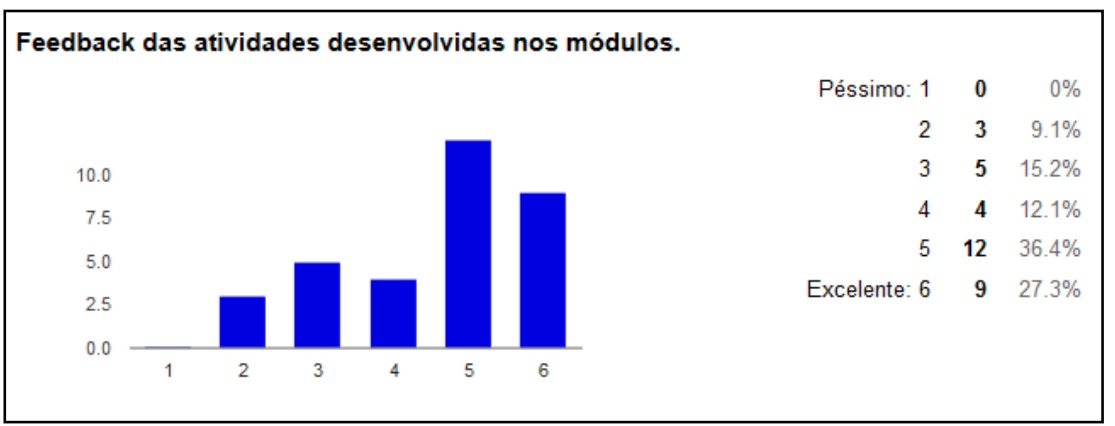

Fonte: dados da pesquisa (2015).

O quarto item avaliou a capacitação dos tutores presenciais para atendimento às demandas dos estudantes. Dos estudantes que responderam, $33,3 \%$ consideram muito bom; $30,3 \%$ excelente; $21,2 \%$ bom; $6,1 \%$ razoável e ruim e $3 \%$ consideram péssimo. $A$ maior parte das respostas concentra-se no nível positivo, porém não se pode desprezar que $27,3 \%$ avaliam como regular e $9,1 \%$ como negativo esse item. Os tutores são a ponte entre o curso e o estudante, se os mesmos não forem bem capacitados essa relação fica comprometida. O gráfico 26 permite visualizar as respostas obtidas.

Gráfico 26 - Capacitação dos tutores presenciais para atendimento aos estudantes

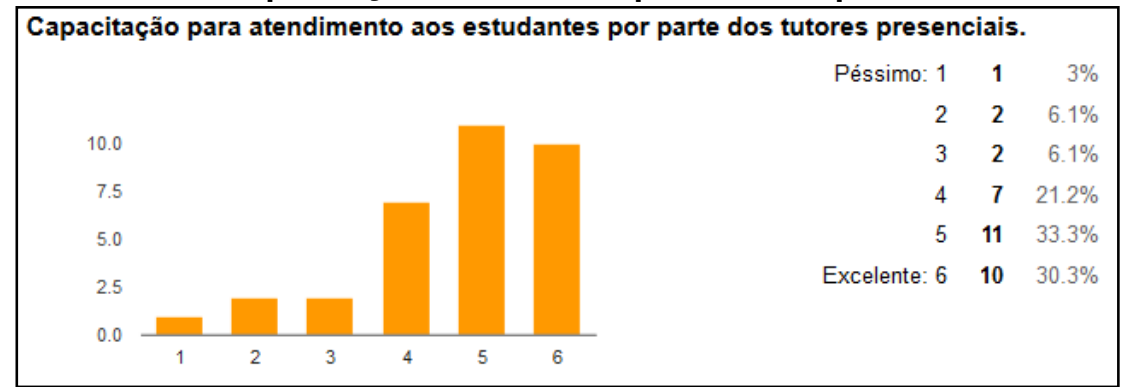

Fonte: dados da pesquisa (2015).

O quinto item avaliou a habilidade de comunicação dos tutores presenciais para atendimento às demandas dos estudantes. Deles, $32,3 \%$ consideram excelente; $25,8 \%$ muito bom e 22,6\% bom, demonstrando que a avaliação desse item é positiva. 
Gráfico 27 - Habilidade de comunicação dos tutores presenciais

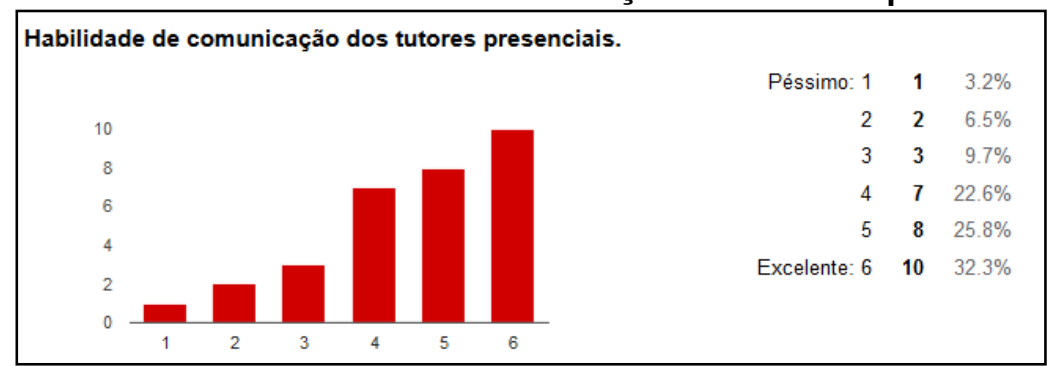

Fonte: dados da pesquisa (2015).

No campo aberto, destinado a comentários sobre tutoria, onze estudantes emitiram a opinião. Elas foram agrupadas, como podemos visualizar na tabela 5. Como os comentários expressam a opinião individual, é interessante observar que dois participantes tiveram visões opostas sobre um mesmo aspecto, o caso do feedback dos tutores, como podemos observar nos comentários de "l" e "J":

"Outra parte deficiente que o curso apresentou diz respeito ao feedback dos tutores em relação à avaliação. As devolutivas pouco contribuíram para a evolução do conhecimento dos estudantes. Na maioria das vezes, o tutor atribuía uma nota para a avaliação, mas não mencionava os aspectos que poderiam ter sido melhor trabalhado naquela atividade, o que não agregou para o conhecimento". (ESTUDANTE I)

"Excelente. Tiveram posturas de profissionais responsáveis, comprometidos, fizeram os feedbacks por aluno de maneira assertiva e pontual". (ESTUDANTE J)

A maior parte de comentários foram elogios, como evidencia o quadro 5 , e, em seguida, a fala do estudante "K".

Quadro 13 - Comentários sobre Tutoria

\begin{tabular}{|l|l|}
\hline \multicolumn{1}{|c|}{ Elogios } & \multicolumn{2}{|c|}{ Críticas } \\
\hline Acolhedores & Águas lindas não teve polo presencial \\
\hline Disponíveis & $\begin{array}{l}\text { Problemas em relação ao feedback das } \\
\text { avaliações }\end{array}$ \\
\hline Excelentes & Perda dos tutores no decorrer do curso \\
\hline $\begin{array}{l}\text { Atuação fervorosa junto à coordenação do } \\
\text { curso }\end{array}$ & Habilidades de comunicação péssima \\
\hline Excelentes na orientação e ensino & \\
\hline Competentes & \\
\hline $\begin{array}{l}\text { Demonstram conhecimento e compreensão } \\
\text { dos conteúdos }\end{array}$ & \\
\hline Responsáveis e comprometidos & \\
\hline Feedback pontual & \\
\hline
\end{tabular}

Fonte: dados da pesquisa (2015). 
"A tutoria demonstrou conhecimento e compreensão, em muitas vezes, ao sanar nossas dúvidas e socorrer em nossos anseios pela busca da aprendizagem, dificuldades que foram surgindo tanto no âmbito educacional quanto no pessoal" (ESTUDANTE K).

Sobre a interação entre tutores e estudantes, a diferença entre as avaliações que consideram esse item como positivo e aqueles que consideram regular e negativa é de apenas $10 \%$. Isso indica que há aspectos que devem ser levados em consideração.

O feedback é um dos pontos mais importantes em um curso à distância, pois permite ao estudante avaliar o desempenho e procurar melhorar, porém se ele não recebe esse retorno, ou o recebe de maneira muito superficial, poderá ficar desmotivado e insatisfeito com o curso.

\subsubsection{Bloco 6 - Ambiente virtual de aprendizagem}

O bloco 6 avaliou o ambiente virtual de aprendizagem - AVA utilizado no curso, o moodle. Foi possível observar, que em relação à localização dos materiais no ambiente, entre os respondentes, $51,5 \%$ consideram excelente e $33,3 \%$ muito bom. $O$ resultado demonstra que a avaliação desse item é positiva. O gráfico 28 permite melhor visualização das respostas.

Gráfico 28 - Localização dos materiais no ambiente

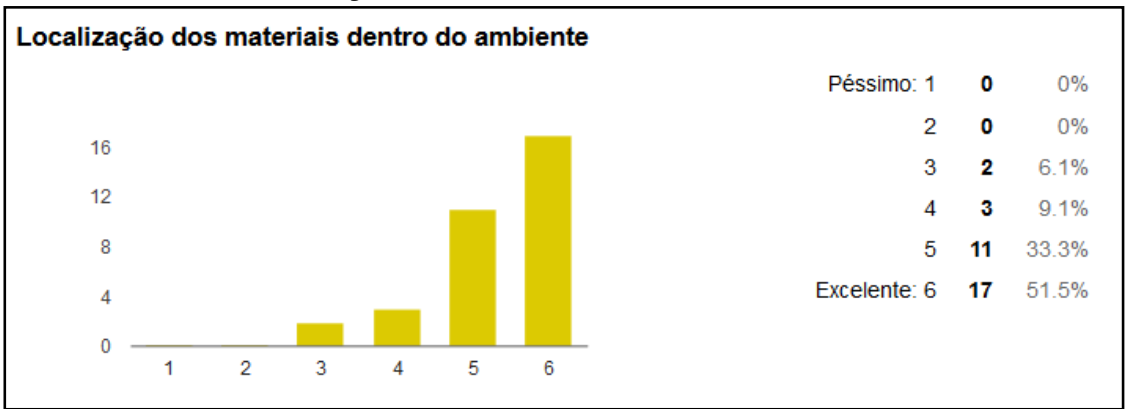

Fonte: dados da pesquisa (2015).

Em relação à comunicação com os docentes e outros estudantes por meio do ambiente, 54,5\% consideram muito bom; 21,2\% acham excelente. Assim, evidencia-se que a avaliação desse item é positiva como pode-se observar no gráfico a seguir. 
Gráfico 29 - Comunicação por meio do ambiente

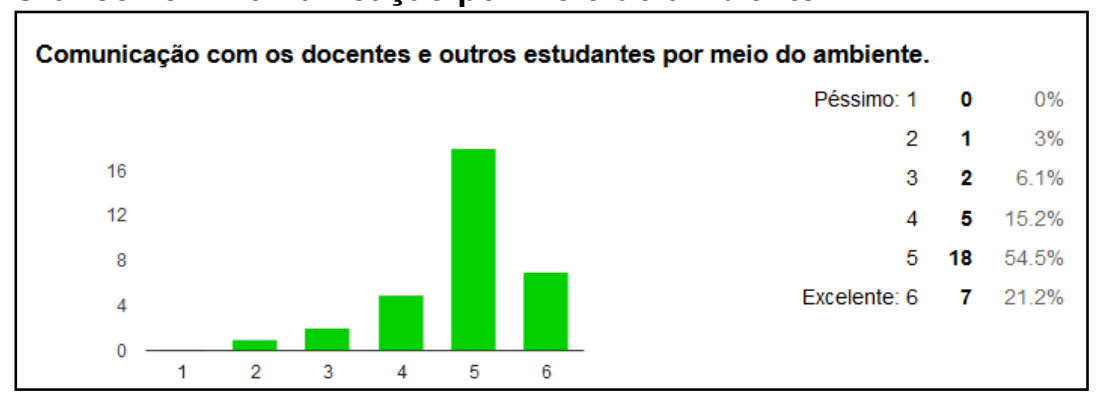

Fonte: dados da pesquisa (2015).

O item três buscou avaliar a facilidade para acessar os recursos como fóruns e chats dentro do ambiente. Verificou-se que 48,5\% consideram muito bom o acesso e $36,4 \%$ avaliam como excelente. O gráfico 30 demonstra os percentuais obtidos.

Gráfico 30 - Acesso aos recursos como fóruns e chat

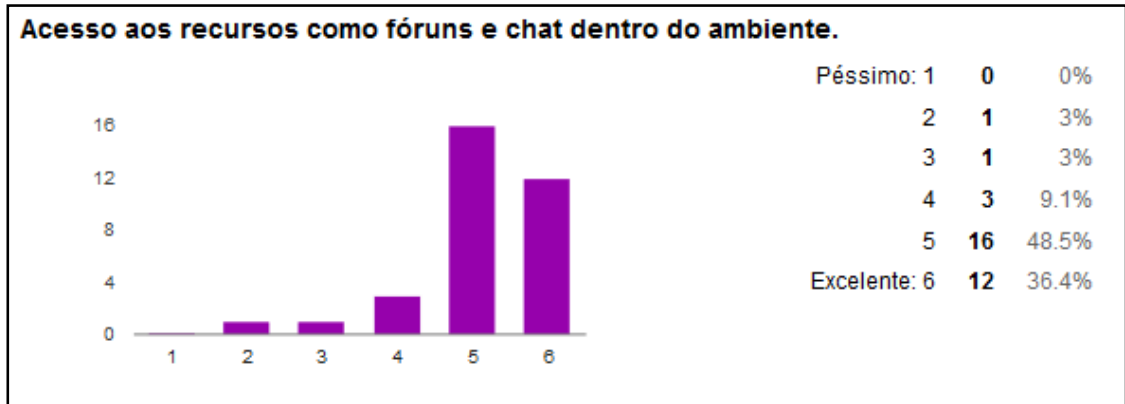

Fonte: dados da pesquisa (2015).

O item seguinte avaliou a praticidade para fazer o download dos arquivos disponibilizados no ambiente. Verificamos que 51,5\% consideram excelente e 42,4\% muito bom, demonstrando que a avaliação desse item foi considerada positiva, como mostra o gráfico 31 .

Gráfico 31 - Download dos arquivos

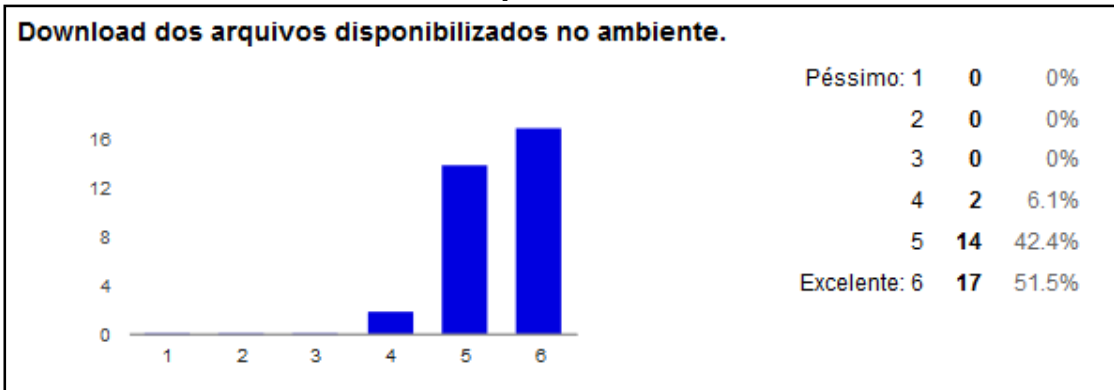

Fonte: dados da pesquisa (2015). 
O item cinco avaliou a interface do ambiente, se era amigável e de fácil compreensão. Entre os estudantes, $45,5 \%$ consideram muito bom e $36,4 \%$ excelente, demonstrando que a avaliação desse item foi considerada positiva, como mostra o gráfico 32.

\section{Gráfico 32 - Interface do ambiente}

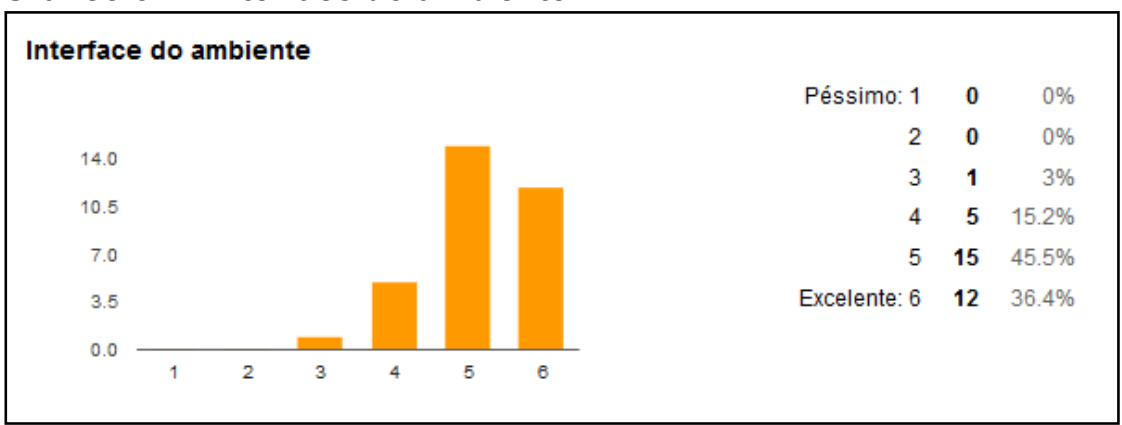

Fonte: dados da pesquisa (2015).

Na parte dos comentários, os estudantes destacaram os seguintes aspectos em relação ao AVA:

\section{Quadro 14 - Comentários sobre o AVA}

\section{Pontos destacados pelos estudantes - AVA}

Acredito que poderíamos ter explorado outras Mídias.

O ambiente virtual é de fácil acesso e os dispositivos de uso estão localizados em lugares

bem visíveis. O programa do ambiente é bem leve, tanto que consegui acessa-lo pelo celular

(é um modelo antigo, que não suporta abrir sites com configuração grande).

Impecável

Bem preparado tanto visual quanto à forma para manuseio (acesso) em geral.

Sendo a primeira experiência em ambiente virtual de aprendizagem gostei muito de como foi organizado o acesso. Foi tranquilo!

Foi interessante estudar usando os meios tecnológicos.

Muito bem estruturado e de fácil acesso.

O ambiente virtual de aprendizagem utilizado o moodle não deixou nada a desejar excelente.

Fonte: dados da pesquisa (2015).

As respostas demonstram que o bloco de questões sobre AVA foi o que obteve a melhor avaliação por parte dos estudantes. Isso pode indicar que o moodle é uma plataforma que atende as demandas satisfatoriamente, ainda que possa melhorar. Os comentários apenas confirmam os dados obtidos nas questões anteriores, destacando características como a facilidade para manusear os recursos e a boa organização. 
Constatou-se também que foi a primeira experiência em um curso EAD para alguns estudantes, e por ter sido satisfatória, pode motivá-los a continuar a formação utilizando essa estratégia.

A avaliação do curso, do ponto de vista dos participantes, apresenta-se condensada no quadro a seguir.

\section{Quadro 15 - Avaliação do CELI pelos participantes do curso}

\begin{tabular}{|c|c|}
\hline Recursos & Avaliação dos Participantes \\
\hline $\begin{array}{l}\text { Estrutura pedagógica do } \\
\text { curso }\end{array}$ & $\begin{array}{l}\text { No que diz respeito à estrutura, foi evidenciado que houve } \\
\text { promoção de aprendizado mais significativo devido ao modo } \\
\text { como foi estruturado, a divisão em eixos temáticos. }\end{array}$ \\
\hline Docentes & $\begin{array}{l}\text { Percebe-se que houve insatisfação com alguns professores } \\
\text { quanto à condução dos debates nos fóruns. } \\
\text { Os aspectos que precisam ser melhorados estão relacionados ao } \\
\text { relacionamento interpessoal com os estudantes, e não aos } \\
\text { conhecimentos e capacidade didática dos docentes, tanto que na } \\
\text { condução do artigo final a maioria considerou a atuação } \\
\text { excelente. }\end{array}$ \\
\hline $\begin{array}{l}\text { Material didático e } \\
\text { estratégias de ensino }\end{array}$ & $\begin{array}{l}\text { Os estudantes mencionaram que poderiam ter sido utilizadas } \\
\text { mídias fora do moodle, consideraram as atividades inovadoras e } \\
\text { desafiadoras e condizentes com o conteúdo. } \\
\text { Um ponto que ficou em déficit foram as web conferências. } \\
\text { É preciso pensar no perfil dos dois profissionais - professores e } \\
\text { bibliotecários -, que participaram do curso, visto que possuem } \\
\text { formações distintas e, consequentemente, niveis de } \\
\text { conhecimento diferentes. Isso possivelmente demanda discussão } \\
\text { mais profunda do corpo docente a respeito das estratégias e } \\
\text { metodologias de ensino. }\end{array}$ \\
\hline Metodologias de avaliação & $\begin{array}{l}\text { Estudantes satisfeitos com as metodologias de avaliação } \\
\text { utilizadas no curso. Os elogios destacaram que as atividades } \\
\text { foram diversificadas e variadas. } \\
\text { Necessidade de propor tarefas diferenciadas. }\end{array}$ \\
\hline Tutoria & $\begin{array}{l}\text { Competentes, disponíveis e demonstram conhecimento e } \\
\text { compreensão do conteúdo. } \\
\text { Críticas relacionadas ao feedback de algumas atividades. }\end{array}$ \\
\hline AVA & $\begin{array}{l}\text { O bloco de questões sobre AVA foi o que obteve a melhor } \\
\text { avaliação por parte dos estudantes. Isso pode indicar que o } \\
\text { moodle é uma plataforma que atende as demandas } \\
\text { satisfatoriamente, ainda que possa melhorar. } \\
\text { Facilidade para manusear os recursos e boa organização. }\end{array}$ \\
\hline
\end{tabular}

Fonte: dados da pesquisa (2016). 


\section{CAPÍTULO 9 \\ CONCLUSÕES E RECOMENDAÇÕES}

A pesquisa é um dos mecanismos de que dispomos para demonstrar a existência ou não de competência em informação. Ela demanda análise cuidadosa dos textos estudados, conhecimento das estratégias de busca e fontes confiáveis para localizar informação relevante, senso crítico e capacidade de reflexão para confrontar os dados com os conhecimentos prévios do pesquisador, e ainda, capacidade de transformar tudo o que foi percebido em novo material, neste caso a tese.

Elaborar uma tese é tarefa complexa de construção de conhecimentos, porém gratificante. Espera-se que a partir deste trabalho outros possam surgir e, quem sabe, ele sirva de instrumento para elucidar dúvidas e questionamentos a respeito do tema.

A contribuição da pesquisa para a Ciência da Informação reside no fato de trazer à tona a discussão sobre a formação continuada em letramento informacional de professores e bibliotecários para que possam atuar na escola. Os resultados apontados pela pesquisa no que diz respeito à competência em informação desses profissionais, tornam o estudo relevante para a área. Além disso, pode servir de apoio para a estruturação de cursos de letramento informacional na modalidade EAD.

Estudar sobre a formação continuada em Letramento Informacional a partir do Curso de Especialização em Letramento Informacional - CELI nos mostrou vários aspectos interessantes. O primeiro deles é que a perspectiva de trabalhar a competência e, consequentemente, o curso em dimensões foi bastante acertada, pois compreendeu-se de antemão que para capacitar indivíduos na tarefa árdua de entender o contexto social, informacional em que vivemos e saber se portar diante dele é preciso pensar de maneira holística, e não em aspectos isolados. Sendo assim, é mérito das autoras Vitorino e Piantola (2011) e também de Rios (2011), que serviram como base para a construção da proposta. Essa concepção sai dos padrões que estamos 
acostumados a adotar na área, e que de certa forma não nos permite aprofundar as discussões, pois a maior parte das pesquisas está centrada nos aspectos técnicos da competência, e não na integração dos outros elementos que a envolve.

Um curso que pretende formar pessoas em Letramento Informacional deve contar com equipes multi, pluri, transdisciplinares, pois a própria temática demanda saberes de diversas áreas, e não apenas da biblioteconomia e educação. O CELI contou com equipe composta prioritariamente de professores dessas duas áreas, e alguns da $\mathrm{TI}$, mas em alguns momentos foi perceptível a falta que uma discussão do corpo docente para alinhar as estratégias faz, como a produção dos materiais por exemplo.

Sobre a análise das dimensões da competência em informação é preciso lembrar que as autoras ao fazerem essa proposta, evidenciam a importância de que são partes de um todo, e que, portanto se complementam e dependem umas das outras, por esse motivo ao realizarmos análises de cada tarefa separadamente o propósito não seria cumprido. Então, ao olharmos de maneira geral, podemos ter outra percepção. Se a competência é saber fazer bem algo, a própria definição, de acordo com Rios (2011), agrega duas dimensões, a técnica do saber fazer, que requer habilidades específicas para o desempenho de uma tarefa, e a política, que está atrelada ao fazer bem, pois esse juízo de valor é estabelecido por meio de padrões sociais do que é considerado um trabalho bem executado. "O que se entende por bem responde a necessidades historicamente definidas pelos homens de uma determinada sociedade" (RIOS, 2011, p.59). Sendo assim, não há como formar educadores para o letramento informacional sem focar nessas duas bases, passando ainda pela ética e estética, que permitem posicionamento crítico a respeito da atuação.

Ao analisar o conteúdo de uma tarefa realizada no primeiro eixo do curso e outra no quinto, fica clara a evolução dos estudantes, ainda que não seja possível afirmar que saíram do curso totalmente competentes em informação, podemos perceber que em diversos aspectos demonstraram que o conhecimento foi adquirido, ou seja, os 
princípios do letramento foram absorvidos, resta saber se na prática cotidiana os mesmos serão aplicados. A construção do conhecimento somente ocorre quando é possível internalizar a informação e fazer relações com os estoques que já possuímos, por esse motivo as pessoas reagem de maneiras diferentes ao se depararem com conteúdos informacionais. Acredita-se que a formação continuada em Letramento Informacional é fundamental para que professores e bibliotecários complementem os conhecimentos e tenham melhores condições de atuar na área educacional, mas essa formação deve estar de acordo com as demandas da contemporaneidade.

Corroboramos com o pensamento de Aquino (2012, p.32), em que a autora aponta os rumos da formação frente às novas tecnologias: "o percurso de formação exige uma atitude de não mais nos contentarmos com a simples aquisição de informações ou apreensão de dados isolados, pois estes não são suficientes para produzir conhecimento". Sendo um curso voltado à capacitação de pessoas para o uso reflexivo da informação, passando por todas as dimensões que isso envolve, deve promover aprendizado que permita ao estudante visão do todo, a aplicação dos conceitos, as suas inter-relações e as possibilidades de construção de conhecimento a partir das informações que recebe, visto que esse é o objetivo da sociedade da aprendizagem.

Os déficits na formação inicial dos participantes do curso são visíveis, pois característica comum à maioria na realização das atividades foi a dificuldade com a produção de textos adequados minimamente às normas gramaticais e culta da língua portuguesa. É preciso destacar a quantidade de erros de concordância, coerência textual e produção de sentido nas tarefas analisadas. Mesmo que o foco da pesquisa fosse o conteúdo relacionado à competência em informação, não é possível deixar de mencionar a qualificação dos profissionais que estamos formando. Tratamos de professores e bibliotecários, profissionais que lidam com pessoas, responsáveis por formar cidadãos críticos e reflexivos, mas a própria formação está cheia de lacunas. Outra dificuldade evidente é a de citar corretamente e evitar o plágio. Na tarefa realizada, na dimensão ética, todos demonstraram preocupação com a questão, mas 
em outras tarefas desenvolvidas ao longo do curso, no momento de aplicar o conhecimento, muitos erros ocorreram. As falhas na formação inicial dos professores e bibliotecários apenas confirmam a necessidade da educação ao longo da vida, sendo a pós-graduação importante instrumento para a qualificação, de modo a atender tanto às demandas do mundo do trabalho, quanto aos anseios individuais, ideia também compartilhada por Belloni (2002).

Um aspecto que poderia ter sido mais explorado no curso foi a prática. Talvez se estratégias mais inovadoras de ensino como a aprendizagem baseada em problemas fosse utilizada, o potencial dos estudantes tivesse sido mais bem explorado, e assim poderíamos aferir aspectos da competência que não foram possíveis de identificar. As plataformas de ensino online permitem o que o ambiente tradicional de sala de aula não proporciona: a possibilidade de desenvolver materiais autoinstrucionais, que congreguem diversos modos de transmitir conteúdo, valendo-se de áudio, vídeo, ilustrações, as quais permitem maior interatividade do estudante com o conhecimento. No caso do CELI, a metodologia adotada foi praticamente repetição da sala de aula, leitura de textos guia, alguns vídeos que complementassem o conteúdo, discussões nos fóruns e realização de atividades avaliativas, nada de inovador.

A educação a distância como estratégia para a formação continuada confirma-se com um grande potencial, verifica-se isso na própria concepção da UAB, que deixa claro que as prioridades dos cursos ofertados pelas universidades públicas, estão relacionadas à formação de professores que atuam na educação básica. A efetividade de um curso a distância transcende a forma como é planejado e a estrutura pedagógica, tecnológica de que dispõe, dependerá de como o estudante se programa para cursar as disciplinas, dedicar tempo para estudo e realização das atividades propostas, e também os propósitos ao cursá-lo.

Em relatório divulgado, em 2014, pela Associação Brasileira de Educação a Distância (ABED), a taxa de evasão média em cursos totalmente à distância é de $19,06 \%$, a do CELI foi bastante alta, 32\% de desistência. Quais foram os motivos que 
levaram a um índice tão alto de evasão? Desmotivação? Dificuldade para concluir as tarefas no prazo? Falta de organização e planejamento? A alta satisfação demonstrada na avaliação realizada pelos estudantes que permaneceram até o final do curso pode ser indicador de que provavelmente não foi a estrutura do curso, a plataforma tecnológica, os docentes nem o material didático utilizado que levou à desistência.

Almeida (2007) aponta que há tendência em considerar as taxas de desistência de cursos a distância para avaliar o sucesso ou fracasso deste, mesmo que essa não seja uma medida muito adequada. Mensurar junto aos estudantes a percepção que tiveram sobre o curso, é fundamental para propor melhorias e ressaltar os aspectos positivos. Nessa medida, a avaliação indica que de maneira geral o curso atendeu às expectativas, levantando como pontos de atenção a questão da interação dos docentes com os estudantes, e o feedback das atividades realizadas, pois sem esse retorno o estudante pode se sentir desmotivado a continuar. Além disso, é preciso tratar das especificidades da atuação tanto de bibliotecários quanto de professores, pois os fazeres profissionais de ambos são distintos. A formação continuada em LI deve contemplar conteúdos que exponham ao professor as possibilidades de atuação na biblioteca, e ao bibliotecário as possibilidades da sala de aula, demonstrando que a parceria é fundamental.

Em resumo, sugerimos que um curso de formação continuada em letramento informacional que pretenda trabalhar na perspectiva das dimensões da competência, deve elaborar atividades que permitam não apenas que o participante demonstre o conhecimento a respeito do tema trabalhado, mas que possa aplicá-los de alguma forma prática seja na escola ou no cotidiano.

Recomenda-se para pesquisas futuras analisar maior número, ou se possível todas as atividades desenvolvidas nos cursos de especialização em Letramento Informacional a fim de avaliar se as metodologias de avaliação estão adequadas às competências que se pretende desenvolver nos participantes. Também é válido avaliar os materiais didáticos utilizados nos cursos para verificar se o conteúdo atende aos 
anseios dos estudantes, dos propósitos das disciplinas e das demandas atuais da sociedade. 


\section{REFERÊNCIAS}

AMERICAN LIBRARY ASSOCIATION. Information literacy competency standards for higher education, $2000 . \quad$ Disponível em: <http://www.ala.org/acrl/standards/informationliteracycompetency>. Acesso em: 15 jun. 2015.

ALMEIDA, Cídio Lopes de. A educação estética de Nietzsche. In: Estética e educação em Nietzsche. São Paulo: Instituto Kora, 2012, p.172-198.

ALMEIDA, Maria Elizabeth Bianconcini de. Educação a distância na internet: abordagens e contribuições dos ambientes digitais de aprendizagem. Educação e Pesquisa, São Paulo, v.29, n.2, p. 327-340, jul./dez. 2003.

ALMEIDA, Onília Cristina de Souza de Almeida. Evasão em cursos a distância: validação de instrumento, fatores influenciadores e cronologia da desistência. 2007. Dissertação (Mestrado em Gestão Social e Trabalho) - Faculdade de Economia, Administração, Contabilidade e Ciência da Informação e Documentação, Universidade de Brasília, Brasília, 2007.

AMARILLA FILHO, Porfírio. Educação a distância: uma abordagem metodológica e didática a partir dos ambientes virtuais. Educação em Revista, Belo Horizonte, v.27, n.02, p.41-72, ago. 2011.

AQUINO, Mirian de Albuquerque. Cenários, espaços e linguagens: uma nova agenda para pensar-conhecer-agir sobre percursos de formação na sociedade da aprendizagem. Informação \& Informação, Londrina, v. 17, n. 1, p. 26-59, jan./jun. 2012.

ARAÚJO JÚNIOR, Rogério Henrique de. Estudo de necessidades de informação dos gerentes do setor editorial e gráfico do Distrito Federal. 1998.178f. Dissertação (Mestrado em Ciência da Informação) - Departamento de Ciência da Informação e Documentação, Universidade de Brasília, Brasília, 1998.

ASSOCIAÇÃO BRASILEIRA DE EDUCAÇÃO A DISTÂNCIA. Censo EaD.br: relatório analítico da aprendizagem a distância no Brasil 2013. Disponível em: <http://www.abed.org.br/site/pt/midiateca/censo_ead/>. Acesso em: 12 jan. 2016.

BAILEY, Jody. Informal screencasting: results of a customer-satisfaction survey with a convenience sample. New Library World, v.113, n. 1/2, p.7-26, 2012.

BAPTISTA, Sofia Galvão; CUNHA, Murilo Bastos da. Estudo de usuários: visão global dos métodos de coleta de dados. Perspectivas em Ciência da Informação, Belo Horizonte, v.12, n.2, p.168-184, maio/ago. 2007. 
BARBASTEFANO, Rafael Garcia; SOUZA, Cristina Gomes de. Percepção do conceito de plágio acadêmico entre alunos de engenharia de produção e ações para sua redução. Revista Produção online, Florianópolis, edição especial, 2007.

BARBOSA, Ricardo Rodrigues; BRUM, Marco Antonio Carvalho. Comportamento de busca e uso da informação: um estudo com alunos participantes de empresas juniores. Perspectivas em ciência da informação, Belo Horizonte, v. 14, n.2, p. 52-75, maio/ago. 2009.

BARDIN, Laurence. Análise de conteúdo. São Paulo: Edições 70, 2011.

BARNHART, Anne C.; STANFIELD, Andrea G. When coming to campus is not an option: using web conferencing to deliver library instruction. Reference Services Review, v.39, n. 1, p.58-65, 2011.

BELLONI, Maria Luiza. Ensaio sobre a educação a distância no Brasil. Educação \& Sociedade, Campinas, ano 23, n. 78, p.117-142, abr. 2002.

BELLUZZO, Regina Célia Baptista. Como desenvolver a Competência em Informação (CI): uma mediação integrada entre a biblioteca e a escola. CRB-8 Digital, São Paulo, v. 1, n. 2, p. 11-14, out. 2008.

- Competências na era digital: desafios tangíveis para bibliotecários e educadores. Educação Temática Digital, Campinas, v.6, n.2, p.30-50, jun. 2005.

. Formação contínua de professores do ensino fundamental sob a ótica do desenvolvimento da information literacy, competência indispensável ao acesso à informação e geração do conhecimento. Transinformação, Campinas, v.16, n.1, p.1732, jan./abr. 2004.

. KERBAUY, Maria Teresa Miceli. Em busca de parâmetros de avaliação da formação contínua de professores do ensino fundamental para o desenvolvimento da information literacy. Educação Temática Digital, Campinas, v.5, n.2, p.129-139, jun. 2004.

Information literacy: um indicador de competência para a formação permanente de professores na sociedade do conhecimento. Educação Temática Digital, Campinas, v.6, n.1, p.81-99, dez. 2004.

BODEN, Catherine ; MURPHY, Susan. The Latent Curriculum: Breaking Conceptual Barriers to Information Architecture. The Canadian Journal of Library and Information Practice and Research, v.7, n. 1, 2012.

BORKO, Harold. Information Science; what is this? American Documentation, v.19, n.1, p.3-5, 1968. 
CAMPELLO, Bernadete Santos. A escolarização da competência em informação. Revista Brasileira de Biblioteconomia e Documentação: Nova Série, São Paulo, v.2, n.2, p.63-77, dez. 2006.

. Letramento Informacional no Brasil: práticas educativas de bibliotecários em escolas de ensino básico. 2009. 208f. Tese (Doutorado em Ciência da Informação) - Escola de Ciência da Informação, Universidade Federal de Minas Gerais, Belo Horizonte, 2009.

O movimento da competência em informação: uma perspectiva para o letramento informacional. Ciência da Informação, Brasília, v. 32, n. 3, p. 28-37, set./dez. 2003.

CAREGNATO, Sônia Elisa. O desenvolvimento de habilidades informacionais: o papel das bibliotecas universitárias no contexto da informação digital em rede. Revista de Biblioteconomia \& Comunicação, Porto Alegre, v.8, p. 47-55, jan./dez. 2000.

CARVALHO, Lívia Ferreira de. Estudo das necessidades informacionais dos gestores das micro e pequenas empresas do Arranjo Produtivo Local de confecção do vestuário de Jaraguá-GO. 2010. 132f. Dissertação (Mestrado em Ciência da Informação) - Faculdade de Ciência da Informação, Universidade de Brasília, Brasília, 2010.

CATALANO, Amy. The Effect of a Situated Learning Environment in a distance education information literacy course. The Journal of Academic Librarianship, v.41, n.5, p.653-659, set. 2015.

CONEGLIAN, André Luís Onório. A inserção da competência em informação em documentos prescritivos e normativos e a prática de professores do ensino fundamental - ciclo I, na cidade de Marília-SP. 2013, 166f. Tese (Doutorado em Ciência da Informação) - Universidade Estadual Paulista, Faculdade de Filosofia e Ciências, 2013.

CONEGLIAN, André Luís O; SANTOS, Camila Araújo dos; CASARIN, Helen de Castro S. Competência em informação e sua avaliação. In: VALENTIM, Marta (Org.). Gestão, mediação e uso da informação. São Paulo: Cultura Acadêmica, 2010. p. 256-275.

CRUZ, José Marcos de Oliveira. Processo de ensino-aprendizagem na Sociedade da Informação. Educ. Soc., Campinas, vol. 29, n. 105, p. 1023-1042, set./dez. 2008.

CUEVAS-CERVERO, Aurora; MARQUES, Márcia; PAIXÃO, Pablo Boaventura Sales. A alfabetização que necessitamos: informação e comunicação para a cidadania. Informação \& Sociedade: Estudos, João Pessoa, v.24, n.2, p. 35-48, maio/ago. 2014.

CUNHA, Murilo Bastos da. Metodologias para estudo dos usuários de informação científica e tecnológica. Revista de Biblioteconomia, Brasília, v.10, n.2, p.5-19, jul./dez. 1982. 
DAVENPORT, Thomas H. Ecologia da Informação: por que só a tecnologia não basta para o sucesso na era da informação. São Paulo: Futura, 1998.

DEMO, Pedro. Ambivalências da sociedade da informação. Ciência da Informação, Brasília, v. 29, n. 2, p. 37-42, maio/ago. 2000.

DIEKEMA, Anne R.; HOLLIDAY, Wendy; LEARY, Heather. Re-framing information literacy: Problem-based learning as informed learning. Library and Information Science Research, v.33, n. 4, p.261-268, 2011.

DUDZIAK, Elisabeth Adriana. Competência em informação: análise evolucionária das tendências da pesquisa e produtividade científica em âmbito mundial. Informação Informação, Londrina, v. 15, n. 2, p. 1 - 22, jul./dez. 2010.

. Em busca da pedagogia da emancipação na educação para a competência em informação sustentável. Revista Digital de Biblioteconomia e Ciência da Informação, Campinas, v.9, n.1, p.166-183, jul./dez. 2011.

. Information Literacy: princípios, filosofia e prática. Ciência da Informação, Brasília, v. 32, n. 1, p. 23-35, jan./abr. 2003.

. Os faróis da sociedade da informação: uma análise crítica sobre a situação da competência em informação no Brasil. Informação \& Sociedade: Estudos, João Pessoa, v.18, n.2, p. 41-53, maio/ago. 2008.

DUPAS, Gilberto. Ética e poder na sociedade da informação: revendo o mito do progresso. Revista brasileira de educação, Rio de Janeiro, n.18, p. 117-122, set./dez. 2001. UNESP, 2001.

. Ética e poder na sociedade da informação. 2.ed. São Paulo: Editora

EKE, Helen Nneka. The perspective of e-learning and libraries in Africa: challenges and opportunities. Library Review, v. 59, n. 4, p.274-290, 2010.

FARIA, Elaine Turk. O professor e as novas tecnologias. In: ENRICONE, Délcia (Org.). Ser Professor. 4. ed. Porto Alegre: EDIPUCRS, 2004. p. 57-72.

FARIAS, Christianne Martins; VITORINO, Elizete Vieira. Competência em informação e dimensões da competência do bibliotecário no contexto escolar. Perspectivas em ciência da informação, Belo Horizonte, v. 14, n. 2, p.2-16, maio/ago. 2009.

FIALHO, Janaina Ferreira. A formação do pesquisador juvenil: um estudo sob o enfoque da competência em informação. 2004. 131f. Dissertação (Mestrado em Ciência da Informação)- Escola de Ciência da Informação, Universidade Federal de Minas Gerais, Belo Horizonte, 2004. 
. CARVALHO, Lívia Ferreira de; RAMOS, Rubem Borges T.; GOMES, Suely Henrique de A. Estudo do Comportamento Informacional dos professores da Universidade Federal de Goiás. In: SEMINÁRIO NACIONAL DE BIBLIOTECAS UNIVERSITÁRIAS, 7., 2012, Gramado. Anais... Gramado: FAURGS, 2012. p.1 a 15.

FERREIRA, Sueli Mara Soares Pinto. Novos paradigmas e novos usuários da informação. Ciência da Informação, Brasília, v. 25, n. 2, p. 217-223, maio/ago., 1995.

FREIRE, Paulo. Pedagogia da autonomia: saberes necessários à prática educativa. 35.ed. São Paulo: Paz e Terra, 1996.

GASQUE, Kelley Cristine Gonçalves Dias. Arcabouço conceitual do letramento informacional. Ciência da Informação, Brasília, v. 39 n. 3, p.83-92, set./dez., 2010.

. Competência em informação: conceitos, características e desafios. Atoz, Curitiba, v. 2, n. 1, p.5-9, jan./jun. 2013.

Letramento informacional: pesquisa, reflexão e aprendizagem. Brasília: Editora FCI/UnB, 2012.

. O papel da experiência na aprendizagem: perspectivas na busca e no uso da informação. TransInformação, Campinas, v.20, n.2, p.149-158, maio/ago., 2008.

O pensamento reflexivo na busca e no uso da informação na comunicação científica. 2008. 240f. Tese (Doutorado em Ciência da Informação)Departamento de Ciência da Informação e Documentação, Universidade de Brasília, Brasília, 2008.

; COSTA, Sely Maria de Souza. Comportamento dos professores da educação básica na busca da informação para a formação continuada. Ciência da Informação, Brasília, v. 32, n. 3, p. 54-61, set./dez. 2003.

; CUNHA, Marcus Vinicius da. A epistemologia de John Dewey e o letramento informacional. TransInformação, Campinas, v.22, n. 2, p.139-146, maio/ago., 2010.

; TESCAROLO, Ricardo. Sociedade da aprendizagem: informação, reflexão e ética. Ciência da Informação, Brasília, v.33, n.3, p.35-40, set./dez. 2004.

. Desafios para implementar o letramento informacional na educação básica. Educação em Revista, Belo Horizonte, v.26, n.01, p.41-56, abr. 2010.

GIL, Antonio Carlos. Métodos e técnicas de pesquisa social. 6.ed. São Paulo: Atlas, 2014.

GOMES, Suely; FIALHO, Janaina; SILVA, Elder do Couto. Competência em informação de agentes envolvidos no Ensino a Distância da Universidade Federal de Goiás Brasil. Revista Interamericana de Bibliotecología, 2013, vol. 36, n.1, p. 47-62. 
GONZALES, Marco; POHLMANN FILHO, Omer; BORGES, Karen Selbach. Informação digital no ensino presencial e a distância. Ciência da Informação, Brasília, v. 30, n. 2, p. 102-111, maio/ago. 2001.

GUIMARÃES, José Augusto Chaves. Moderno profissional da informação: elementos para sua formação no Brasil. Transinformação, Campinas, v. 9, n. 1, p. 124-137, jan./abr. 1997.

HATSCHBACH, Maria Helena de Lima; OLINTO, Gilda. Competência em informação: caminhos percorridos e novas trilhas. Revista Brasileira de Biblioteconomia e Documentação, Nova Série, São Paulo, v.4, n.1, p. 20-34, jan./jun. 2008.

HEATHER, Nicholson; NICOLE, Eva. Information literacy instruction for satellite university students. Reference Services Review, v.39, n. 3, p.497-513, 2011.

KILIC - CAKMAK, Ebru. Learning Strategies and Motivational Factors Predicting Information Literacy Self-Efficacy of E-Learners. Australasian Journal of Educational Technology, v.2, n2, p.192-208, 2010.

KRATOCHVIL, Jiri Evaluation of e-learning course, Information Literacy, for medical students. Electronic Library, v.31, n. 1, p.55-69, 2013.

KROKOSCZ, Marcelo. Abordagem do plágio nas três melhores universidades de cada um dos cinco continentes e do Brasil. Revista Brasileira de Educação, Rio de Janeiro, v. 16, n. 48, p.745-818, set.-dez. 2011.

LECARDELLI, Jane; PRADO, Noêmia Schoffen. Competência em informação no Brasil: um estudo bibliográfico no período de 2001 a 2005. Revista Brasileira de Biblioteconomia e Documentação, Nova Série, São Paulo, v.2, n.2, p.21-46, dez. 2006.

LE COADIC, Yves-François. A ciência da informação. Brasília: Briquet de Lemos, 2004.

MADEIRA, Carla de Castro Gomes. A educação a distância na formação continuada de professores: uma reflexão. 2006. 96f. Dissertação (Mestrado em Educação) Faculdade de Educação, Universidade Federal do Rio Grande do Sul, Porto Alegre, 2006.

MARTINEZ-SILVEIRA, Martha; ODDONE, Nanci. Necessidades e comportamento informacional: conceituação e modelos. Ciência da Informação, Brasília, v. 36, n. 1, p.118-127, maio/ago. 2007.

MARTINS, Onilza Borges. Os caminhos da EAD no Brasil. Revista Diálogo Educ., Curitiba, v. 8, n. 24, p. 357-371, maio/ago. 2008. 
MATA, Marta Leandro da; CASARIN, Helen de Castro Silva. Inserção de conteúdo de competência em informação e de formação pedagógica nos currículos dos cursos de biblioteconomia do Brasil: uma análise por meio dos sites institucionais. In: ENCONTRO NACIONAL DE PESQUISA EM CIÊNCIA DA INFORMAÇÃO, 13., 2012, Rio de Janeiro. Anais... Rio de Janeiro: FIOCRUZ, 2012.

MINISTÉRIO DA EDUCAÇÃO, Secretaria de Educação a distância. Referenciais de qualidade para educação superior a distância. Brasília, 2007.

MIRANDA, Silvânia. Como as necessidades de informação podem se relacionar com as competência em informação. Ciência da Informação, Brasília, v.35, n.3, p.99-114, set./dez.2006.

- Identificando competência em informação. Ciência da Informação, Brasília, v. 33, n. 2, p. 112-122, maio/ago. 2004.

MORAN, José Manuel. Ensino e aprendizagem inovadores com tecnologias. Informática na educação: teoria e prática, Porto Alegre, v.3, n.1, p. 137-144, set. 2000.

MOTA, Francisca Rosaline Leite. Competência em informação e necessidade de interação entre bibliotecários e professores no contexto escolar. Informação \& Sociedade: Est., João Pessoa, v.16, n.1, p.121-127, jan./jun. 2006.

MUELLER, Suzana Pinheiro Machado. Perfil do Bibliotecário, serviços e responsabilidades na área de informação e formação profissional. Revista de Biblioteconomia de Brasília, v. 17, p. 63-70, jan./jun. 1989.

NAZARI, Maryam. A contextual model of information literacy. Journal of Information Science, Aug v.37, n.4, p.345-359, 2011.

; WEBBER, Sheila. Loss of Faith in the Origins of Information Literacy in EEnvironments: Proposal of a Holistic Approach. Journal of Librarianship and Information Science, v.44, n. 2, p.97-107, 2012.

OLETO, Ronaldo Ronan. Percepção da qualidade da informação. Ciência da Informação, Brasília, v. 35, n. 1, p. 57-62, jan./abr. 2006.

ORELO, Eliane Rodrigues Mota; VITORINO, Elizete Vieira. Competência em informação: um olhar para a dimensão estética. Perspectivas em Ciência da Informação, Belo Horizonte, v.17, n.4, p.41-56, out./dez. 2012.

PINTO, Carmen Lúcia Lascano; BARREIRO, Cristhianny Bento; SILVEIRA, Denise do Nascimento. Formação continuada de professores: ampliando a compreensão acerca deste conceito. Revista Thema, Pelotas, v.7, n.1, p.1-14, 2010. 
POZO, Juan Ignacio. Sociedade da aprendizagem e o desafio de converter informação em conhecimento. Revista Pátio, ano 8, ago./out. 2004, p.34-36. Disponível em: <http://www.udemo.org.br/A\%20sociedade.pdf>. Acesso em: 04 ago. 2014.

RIOS, Terezinha Azerêdo. Compreender e ensinar: por uma docência da melhor qualidade. 8.ed. São Paulo: Cortez, 2010.

. Ética e competência. 20.ed. São Paulo: Cortez, 2011.

ROCHA, Marisa Perrone Campos. A questão cidadania na sociedade da informação. Ciência da Informação, Brasília, v. 29, n. 1, p. 40-45, jan./abr. 2000.

RODRIGUES, Leda Maria Borges da Cunha; CAPELLINI, Vera Lúcia Messias Fialho. Educação a distância e formação continuada do professor. Revista Brasileira de Educação Especial, Marília, v. 18, n. 4, p. 615-628, out./dez. 2012.

ROZADOS, Helen Beatriz Frota. Objetos de aprendizagem no contexto da construção do conhecimento. C\&D-Revista Eletrônica da Fainor, Vitória da Conquista, v.2, n.1, p.46-63, jan./dez. 2009.

SANTOS, Elisangela Marina dos Santos; DUARTE, Elizabeth Andrade; PRATA, Nilson Vidal. Cidadania e trabalho na sociedade da informação: uma abordagem baseada na competência em informação. Perspectivas em Ciência da Informação, Belo Horizonte, v.13, n. 3, p.208-222, set./dez., 2008.

SANTOS, Mônica de Paiva. Competência em informação: um estudo com os professores associados I do Centro de Tecnologia da UFPB. 2010.186f. Dissertação (Mestrado em Ciência da Informação)- Centro de Ciências Sociais Aplicadas, Universidade Federal da Paraíba, João Pessoa, 2010.

SANTOS, Plácida Leopoldina Ventura Amorim da Costa; CARVALHO, Ângela Maria Grossi de. Sociedade da Informação: avanços e retrocessos no acesso e no uso da informação. Informação \& Sociedade: Est., João Pessoa, v.19, n.1, p. 45-55, jan./abr. 2009.

SANTOS, Thalita Franco dos. Competência em informação no ensino superior: um estudo de discentes de graduação em biblioteconomia no estado de Goiás. 2011. 148f. Dissertação (Mestrado em Ciência da Informação)-Faculdade de Ciência da Informação, Universidade de Brasília, Brasília, 2011.

SILVA, Carla Maria T. de Sousa da. ; ARRUDA, Guilhermina Melo. A formação do profissional de biblioteconomia frente às novas tendências do mercado globalizado. Encontros Bibli, Florianópolis, n. 6, p. 1-11, set. 1998.

SILVA, Helena et al. Inclusão digital e educação para a competência em informação: uma questão de ética e cidadania. Ciência da Informação, Brasília, v. 34, n. 1, p. 2836, jan./abr. 2005. 
TANG, Yingqi. Distance Education Librarians in the United States: A Study of Job Announcements. The Journal of Academic Librarianship, v.39, n 6, p.500-505, 2013.

; TSENG, Hung Wei. Distance Learners' Self-efficacy and Information Literacy Skills. The Journal of Academic Librarianship, v.39, n. 6, p.517-521, 2013.

TARGINO, Maria das Graças. Biblioteconomia, informação e cidadania. Revista da escola de biblioteconomia da UFMG, Belo Horizonte, v.20, n.2, p.149-160, jul./dez. 1991.

TOMANIK, Eduardo Augusto. O olhar no espelho: conversas sobre a pesquisa em ciências sociais. 2.ed. Maringá: Eduem, 2004.

VALENTIM, Marta Lígia Pomim. O moderno profissional da informação: formação e perspectiva profissional. Encontros Bibli, Florianópolis, n.9, p.1-10, 2000.

VAN DE VORD, Rebecca. Distance Students and Online Research: Promoting Information Literacy through Media Literacy. Internet and Higher Education, v.13, n. 3, p.170-175, 2010.

VITORINO, Elizete Vieira. A formação contínua do profissional da informação: princípios epistemológicos à competência em informação. In: ENCONTRO NACIONAL DE PESQUISA EM CIÊNCIA DA INFORMAÇÃO, 9., 2008, São Paulo. Anais... São Paulo: USP, 2008. p. 1 a 15.

. Princípios epistemológicos à competência em informação do profissional da informação. In: CONGRESO ISKO ESPAÑA, 9., 2009, Valencia. Anais... Valencia: Universidad Politécnica de Valencia, 2009, p.48-69

; PIANTOLA, Daniela. Competência em informação - bases históricas e conceituais: construindo significados. Ciência da Informação, Brasília, v. 38, n. 3, p.130-141, set./dez., 2009.

; PIANTOLA, Daniela. Dimensões da competência em informação. Ciência da Informação, Brasília, v. 40 n. 1, p.99-110, jan./abr., 2011.

UNESCO. Alfabetização midiática e informacional: currículo para formação de professores. Brasília: UNESCO, UFTM, 2013. 194 p. Disponível em: $<$ http://unesdoc.unesco.org/images/0022/002204/220418por.pdf>. Acesso em: 02 Maio 2014.

WERTHEIN, Jorge. A sociedade da informação e seus desafios. Ciência da Informação, Brasília, v. 29, n. 2, p. 71-77, maio/ago. 2000.

ZUIN, Antônio A. S. Educação a distância ou educação distante?O programa Universidade Aberta do Brasil, o tutor e o professor virtual. Educ. Soc., Campinas, vol. 27, n. 96 - Especial, p. 935-954, out. 2006. 


\section{APÊNDICES}




\section{APÊNDICE 1 - MODELO DE QUESTIONÁRIO AVALIATIVO APLICADO AOS ALUNOS DO CURSO}

\section{PESQUISA DE DOUTORADO - ANÁLISE DA INFLUÊNCIA DO CELI NO DESENVOLVIMENTO DE COMPETÊNCIA EM INFORMAÇÃO PELOS ESTUDANTES PARTICIPANTES \\ UNIVERSIDADE DE BRASÍLIA PROGRAMA DE PÓS-GRADUAÇÃO EM CIÊNCIA DA INFORMAÇÃO}

Brasília, 10 de Novembro de 2015.

Prezado estudante,

Estamos realizando uma pesquisa visando a coleta de dados para a concretização do Doutorado em Ciência da Informação, da Universidade de Brasília, sob orientação da Profa Dra. Kelley Cristine Gasque.

O objetivo principal desse estudo é compreender de que modo o CELI - Curso de Especialização em Letramento Informacional auxiliou no desenvolvimento de competência em informação dos estudantes participantes. Os dados obtidos por meio deste formulário serão utilizados apenas para os propósitos deste estudo e os resultados poderão ser apresentados em eventos e revistas de caráter científico e acadêmico.

Para garantir maior liberdade de participação e de opinião, não serão solicitados dados que possam identificar os participantes, garantindo o sigilo e a privacidade destes na pesquisa aqui apresentada.

Desde já agradecemos a sua participação.

Atenciosamente, Professora e pesquisadora Lívia Ferreira de Carvalho. 


\section{Bloco 1 - Estrutura do curso}

Em relação à estrutura pedagógica do curso, avalie os itens a seguir. Lembrando que a escala varia de 1-péssimo até 6 -excelente.

\begin{tabular}{|c|c|c|c|c|c|c|}
\hline VARIÁVEIS ESCALA & $\begin{array}{c}1 \\
\text { Péssimo }\end{array}$ & $\begin{array}{c}2 \\
\text { Ruim }\end{array}$ & $\begin{array}{c}3 \\
\text { Razoável }\end{array}$ & $\begin{array}{c}4 \\
\text { Bom }\end{array}$ & $\begin{array}{c}5 \\
\text { Muito bom }\end{array}$ & $\begin{array}{c}6 \\
\text { Excelente }\end{array}$ \\
\hline - A divisão do curso em eixos. & $(）$ & $(）$ & $(）$ & ( ) & () & () \\
\hline $\begin{array}{l}\text { - A concepção pedagógica em } \\
\text { dimensões. }\end{array}$ & ( ) & ( ) & ( ) & ( ) & $(）$ & ( ) \\
\hline $\begin{array}{l}\text { - Conteúdo trabalhado no eixo } \\
\text { 1-Teórico conceitual }\end{array}$ & ( ) & ( ) & ( ) & ( ) & $(）$ & $(）$ \\
\hline $\begin{array}{l}\text { - Conteúdo trabalhado no eixo } \\
\text { 2-Dimensão estética }\end{array}$ & ( ) & ( ) & ( ) & ( ) & $(）$ & $(）$ \\
\hline $\begin{array}{l}\text { - Conteúdo trabalhado no eixo } \\
\text { 3-Dimensão político pedagógica }\end{array}$ & ( ) & ( ) & $(）$ & ( ) & $(）$ & ( ) \\
\hline $\begin{array}{l}\text { - Conteúdo trabalhado no eixo } \\
\text { 4-Dimensão ética }\end{array}$ & ( ) & ( ) & ( ) & $(）$ & $(）$ & ( ) \\
\hline $\begin{array}{l}\text { - Conteúdo trabalhado no eixo } \\
\text { 5-Dimensão técnica }\end{array}$ & ( ) & ( ) & ( ) & $(）$ & $(）$ & $(）$ \\
\hline $\begin{array}{l}\text { - Conteúdo trabalhado no eixo } \\
\text { 6-Metodológico }\end{array}$ & ( ) & ( ) & ( ) & ( ) & ( ) & ( ) \\
\hline - Comentários & & & & & & \\
\hline
\end{tabular}

\section{Bloco 2 - Docentes}

Em relação à atuação dos docentes no curso, avalie os itens a seguir. Lembrando que a escala varia de 1-péssimo até 6-excelente.

\begin{tabular}{|c|c|c|c|c|c|c|}
\hline VARIÁVEIS ESCALA & $\begin{array}{c}1 \\
\text { Péssimo }\end{array}$ & $\begin{array}{c}2 \\
\text { Ruim }\end{array}$ & $\begin{array}{c}3 \\
\text { Razoável }\end{array}$ & $\begin{array}{c}4 \\
\text { Bom }\end{array}$ & $\begin{array}{c}5 \\
\text { Muito bom }\end{array}$ & $\begin{array}{c}6 \\
\text { Excelente }\end{array}$ \\
\hline $\begin{array}{l}\text { - Capacitação para condução } \\
\text { das disciplinas. }\end{array}$ & ( ) & ( ) & ( ) & ( ) & ( ) & ( ) \\
\hline $\begin{array}{l}\text { - Participação nos fóruns de } \\
\text { discussão. }\end{array}$ & ( ) & ( ) & ( ) & () & ( ) & ( ) \\
\hline $\begin{array}{l}\text { - Disposição para auxiliar o } \\
\text { estudante em suas dúvidas. }\end{array}$ & ( ) & ( ) & ( ) & () & () & () \\
\hline $\begin{array}{l}\text { - Relacionamento interpessoal } \\
\text { com o estudante. }\end{array}$ & ( ) & ( ) & ( ) & $(\quad)$ & ( ) & ( ) \\
\hline $\begin{array}{l}\text { - Quantidade de docentes por } \\
\text { módulos. }\end{array}$ & ( ) & ( ) & ( ) & () & () & () \\
\hline $\begin{array}{l}\text { - Condução das orientações } \\
\text { do artigo final. }\end{array}$ & ( ) & $(\quad)$ & ( ) & $(\quad)$ & ( ) & ( ) \\
\hline - Comentários. & & & & & & \\
\hline
\end{tabular}


Bloco 3 - Material didático e estratégias de ensino

Em relação ao material didático e estratégias de ensino utilizados no curso, avalie os itens a seguir. Lembrando que a escala varia de 1-péssimo até 6-excelente.

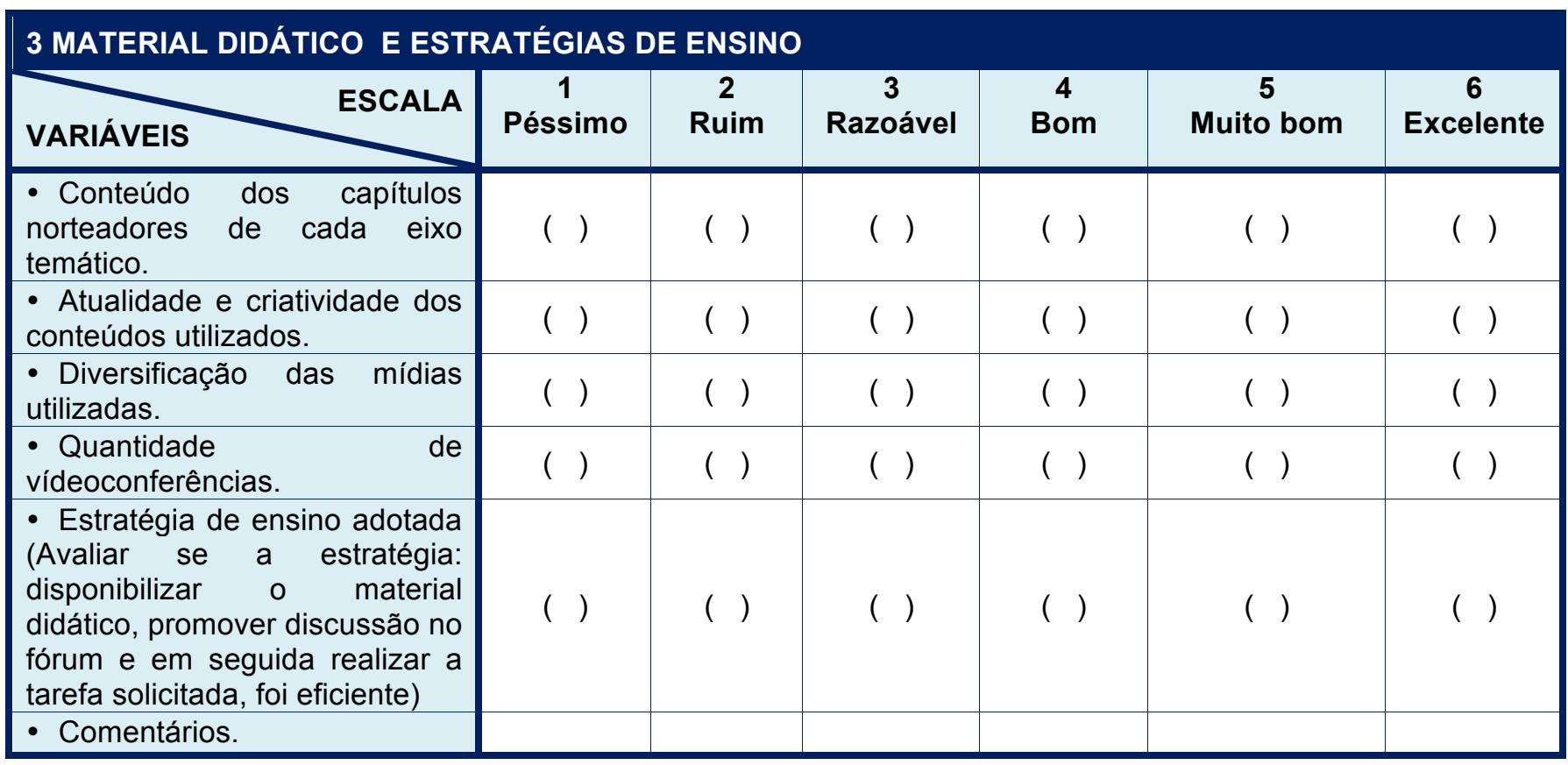

Bloco 4 - Metodologias de avaliação

Em relação às metodologias utilizadas para a avaliação do seu desempenho, avalie os itens a seguir. Lembrando que a escala varia de 1-péssimo até 6-excelente.

\begin{tabular}{|c|c|c|c|c|c|c|}
\hline VARIÁVEIS ESCALA & $\begin{array}{c}1 \\
\text { Péssimo }\end{array}$ & $\begin{array}{c}2 \\
\text { Ruim }\end{array}$ & $\begin{array}{c}3 \\
\text { Razoável }\end{array}$ & $\begin{array}{c}4 \\
\text { Bom }\end{array}$ & $\begin{array}{c}5 \\
\text { Muito bom }\end{array}$ & $\begin{array}{c}6 \\
\text { Excelente }\end{array}$ \\
\hline $\begin{array}{l}\text { - Pertinência das atividades } \\
\text { em relação ao conteúdo } \\
\text { ministrado nos módulos. }\end{array}$ & ( ) & （ ） & ( ) & ( ) & ( ) & ( ) \\
\hline - Diversificação das atividades. & ( ) & $(）$ & ( ) & ( ) & ( ) & ( ) \\
\hline $\begin{array}{l}\text { - Atividades que exploram o } \\
\text { potencial de interpretação e } \\
\text { capacidade de reflexão do } \\
\text { estudante. }\end{array}$ & （ ） & （ ） & ( ) & ( ) & ( ) & ( ) \\
\hline - Comentários & & & & & & \\
\hline
\end{tabular}




\section{Bloco 5 - Tutoria}

Em relação à tutoria, avalie os itens a seguir. Lembrando que a escala varia de 1-péssimo até 6excelente.

\begin{tabular}{|c|c|c|c|c|c|c|}
\hline \multicolumn{7}{|l|}{5 TUTORIA } \\
\hline VARIÁVEIS ESCALA & $\begin{array}{c}1 \\
\text { Péssimo }\end{array}$ & $\begin{array}{c}2 \\
\text { Ruim }\end{array}$ & $\begin{array}{c}3 \\
\text { Razoável }\end{array}$ & $\begin{array}{c}4 \\
\text { Bom }\end{array}$ & $\begin{array}{c}5 \\
\text { Muito bom }\end{array}$ & $\begin{array}{c}6 \\
\text { Excelente }\end{array}$ \\
\hline $\begin{array}{l}\text { - Nível de conhecimento dos } \\
\text { tutores à distância acerca dos } \\
\text { assuntos abordados nas } \\
\text { disciplinas. }\end{array}$ & ( ) & ( ) & ( ) & ( ) & ( ) & ( ) \\
\hline $\begin{array}{l}\text { - Interação dos tutores à } \\
\text { distância com os estudantes } \\
\text { nos fóruns. }\end{array}$ & ( ) & ( ) & ( ) & ( ) & ( ) & ( ) \\
\hline $\begin{array}{l}\text { - Feedback das atividades } \\
\text { desenvolvidas nos módulos. }\end{array}$ & ( ) & ( ) & ( ) & $(\quad)$ & ( ) & ( ) \\
\hline $\begin{array}{l}\text { - Capacitação para } \\
\text { atendimento aos estudantes por } \\
\text { parte dos tutores presenciais. }\end{array}$ & ( ) & ( ) & ( ) & () & ( ) & ( ) \\
\hline $\begin{array}{l}\text { - Habilidade de comunicação } \\
\text { dos tutores presenciais. }\end{array}$ & ( ) & ( ) & ( ) & $(\quad)$ & ( ) & ( ) \\
\hline - Comentários. & & & & & & \\
\hline
\end{tabular}

\section{Bloco 6 -Ambiente virtual de aprendizagem}

Em relação ao ambiente virtual de aprendizagem utilizado (moodle), avalie os itens a seguir. Lembrando que a escala varia de 1-péssimo até 6-excelente.

\section{AMBIENTE VIRTUAL DE APRENDIZAGEM}

\begin{tabular}{|c|c|c|c|c|c|c|}
\hline VARIÁVEIS ESCALA & $\begin{array}{c}1 \\
\text { Péssimo }\end{array}$ & $\begin{array}{c}2 \\
\text { Ruim }\end{array}$ & $\begin{array}{c}3 \\
\text { Razoável }\end{array}$ & $\begin{array}{c}4 \\
\text { Bom }\end{array}$ & $\begin{array}{c}5 \\
\text { Muito bom }\end{array}$ & $\begin{array}{c}6 \\
\text { Excelente }\end{array}$ \\
\hline $\begin{array}{l}\text { - Localização dos materiais } \\
\text { dentro do ambiente. (Consiste } \\
\text { na facilidade para encontrar os } \\
\text { materiais disponibilizados nas } \\
\text { disciplinas). }\end{array}$ & （） & （） & （） & ( ) & （） & ( ) \\
\hline $\begin{array}{l}\text { - Comunicação com os } \\
\text { docentes e outros estudantes } \\
\text { por meio do ambiente. }\end{array}$ & ( ) & ( ) & ( ) & () & ( ) & ( ) \\
\hline $\begin{array}{l}\text { - Acesso aos recursos como } \\
\text { fóruns e chat dentro do } \\
\text { ambiente. }\end{array}$ & （） & ( ) & ( ) & ( ) & ( ) & ( ) \\
\hline $\begin{array}{l}\text { - Download os arquivos } \\
\text { disponibilizados no ambiente. } \\
\text { (Consiste na facilidade em } \\
\text { baixar os arquivos do ambiente } \\
\text { para o seu computador } \\
\text { pessoal). }\end{array}$ & ( ) & ( ) & ( ) & () & ( ) & ( ) \\
\hline $\begin{array}{l}\text { - Interface do ambiente. } \\
\text { (Consiste na apresentação do } \\
\text { moodle. A disposição dos }\end{array}$ & ( ) & ( ) & ( ) & () & ( ) & ( ) \\
\hline
\end{tabular}




\begin{tabular}{|l|l|l|l|l|l|l|}
\hline $\begin{array}{l}\text { elementos na página é um } \\
\text { exemplo). }\end{array}$ & & & & & & \\
\hline - Comentários & & & & & & \\
\hline
\end{tabular}

